Supporting Information for

\title{
Phenanthro[b]-Fused BODIPYs through Tandem Suzuki and Oxidative Aromatic Couplings: Synthesis and Photophysical Properties
}

Wei Miao, ${ }^{a}$ Yuanmei Feng, ${ }^{a}$ Qinghua Wu, ${ }^{a}$ Wanle Sheng, ${ }^{a}$ Mao Li, ${ }^{a}$ Qingyun Liu, ${ }^{b}$ Erhong Hao, ${ }^{a}$ and Lijuan Jiao $*^{a}$

${ }^{a}$ Laboratory of Functional Molecular Solids, Ministry of Education; School of Chemistry and Materials Science, Anhui Normal University, Wuhu, 241002, China;

${ }^{\mathrm{b}}$ College of Chemistry and Environmental Engineering, Shandong University of Science and Technology, Qingdao, China.

*To whom correspondence should be addressed.

E-mail: haoehong@ahnu.edu.cn, jiao421@ahnu.edu.cn

\section{Contents:}

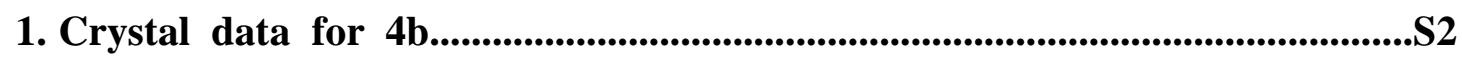

2. Cyclic voltammograms of BODIPYs 4e and 6...................................................S5

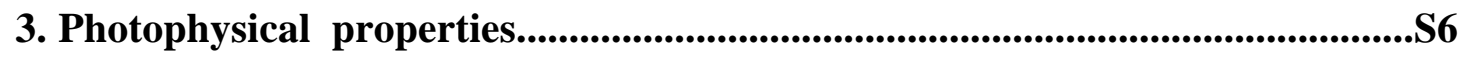

4. Copies of ${ }^{1} \mathrm{H}$ and ${ }^{13} \mathrm{C}\left\{{ }^{1} \mathrm{H}\right\}$ NMR spectra.....................................S30

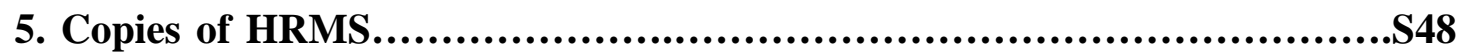

6. DFT calculation.....................................................................S59 


\section{Crystal data for $4 b$}

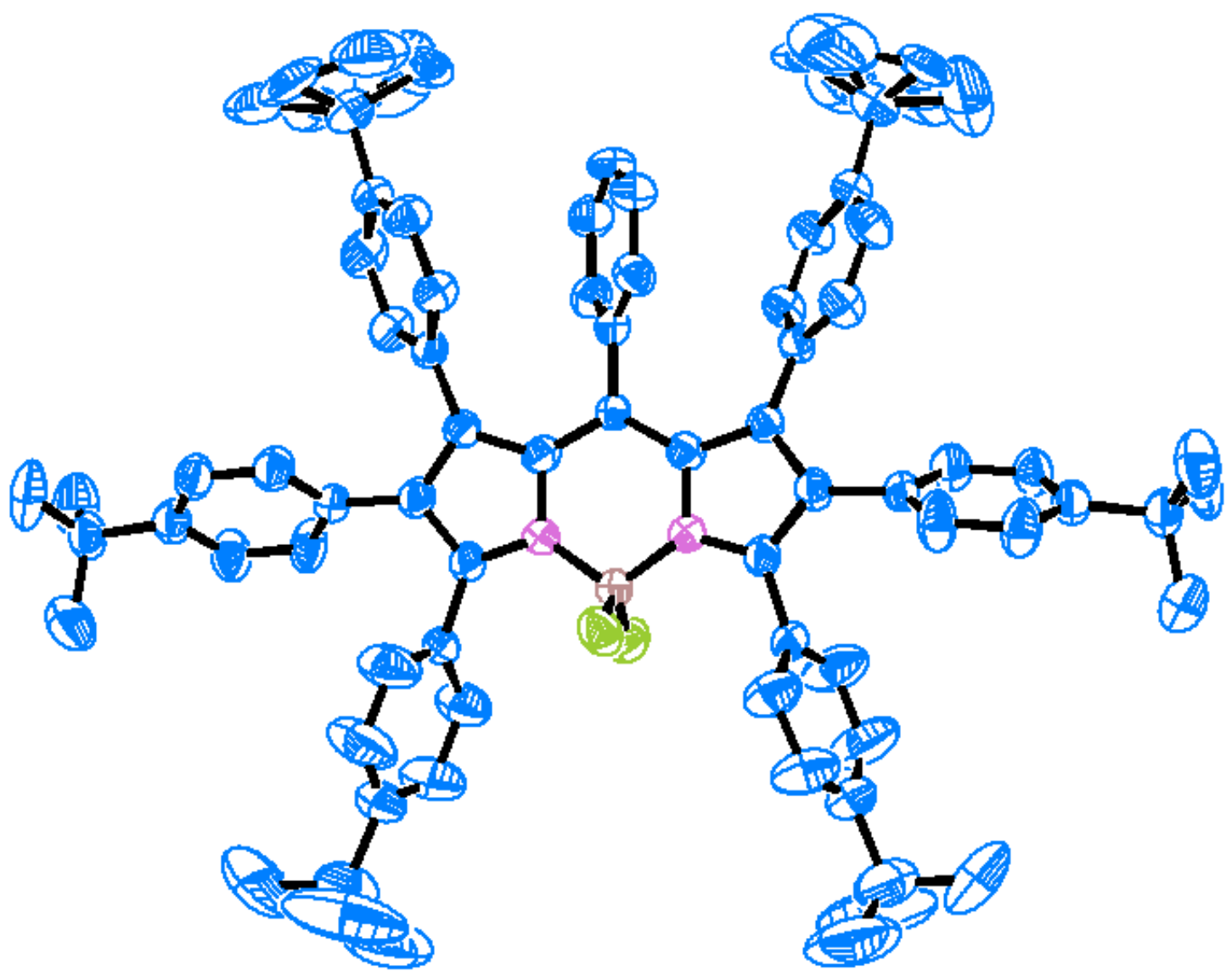

Figure S1. ORTEP plot of $\mathbf{4 b}$ with thermal ellipsolids at 50\% probability level. C slateblue, $\mathrm{N}$ orchid, F yellowgreen, B pink. Hydrogen atoms were omitted for clarity. 
Table S1. Selected geometrical parameters of compound $\mathbf{4 b}$ obtained from crystallography

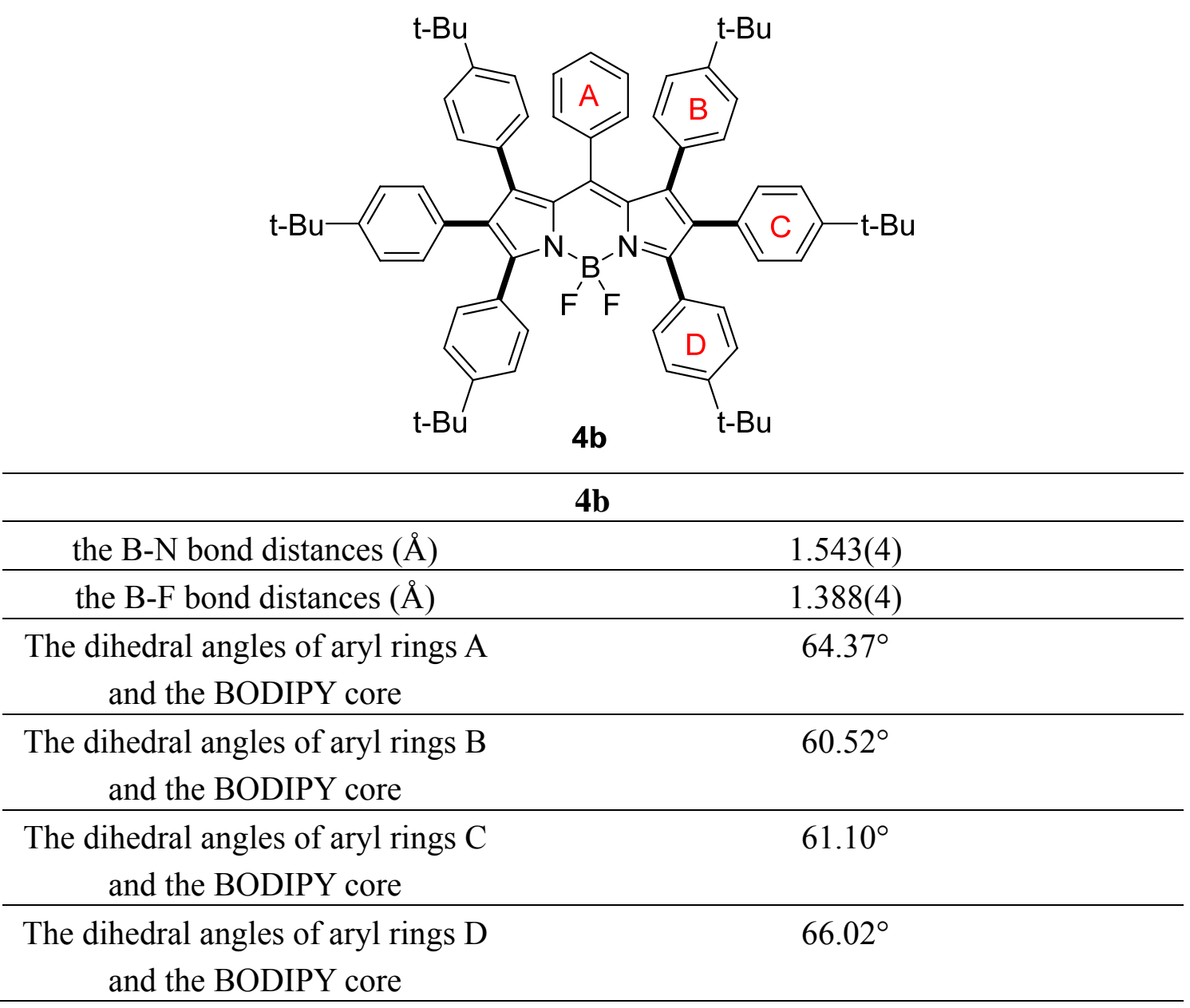


Table S2. Crystallographic data and details of the structure determinations of BODIPY $\mathbf{4 b}$

\begin{tabular}{|c|c|}
\hline & 4b \\
\hline Empirical formula & $\mathrm{C}_{75} \mathrm{H}_{65} \mathrm{~B} \mathrm{~F}_{2} \mathrm{~N}_{2}$ \\
\hline Formula weight & 1043.10 \\
\hline Temperature $[\mathrm{K}]$ & 293(2) \\
\hline Wavelength & 0.71073 \\
\hline Crystal system & orthorhombic \\
\hline space group & $\mathrm{C} 222_{1}$ \\
\hline $\mathrm{a}[]$ & $9.4881(8)$ \\
\hline $\mathrm{b}[]$ & $34.080(4)$ \\
\hline $\mathrm{c}[]$ & $21.122(2)$ \\
\hline$\alpha\left[^{\circ}\right]$ & 90 \\
\hline$\beta\left[^{\circ}\right]$ & 90 \\
\hline$\gamma\left[^{\circ}\right]$ & 90 \\
\hline $\mathrm{V}[]$ & $6829.9(11)$ \\
\hline Z & 4 \\
\hline$\rho_{\text {calc }} \mathrm{g} / \mathrm{cm}^{3}$ & 1.722 \\
\hline$\mu / \mathrm{mm}^{-1}$ & 0.193 \\
\hline $\mathrm{F}(000)$ & 3539 \\
\hline Crystal size (mm) & $0.23 \times 0.22 \times 0.22$ \\
\hline Radiation & $\operatorname{MoK} \alpha(\lambda=0.71073)$ \\
\hline $2 \Theta$ range for data collection $/{ }^{\circ}$ & 5.594 to 55.192 \\
\hline Index ranges & $-12 \leq \mathrm{h} \leq 12,-44 \leq \mathrm{k} \leq 44,-27 \leq 1 \leq 27$ \\
\hline Reflections collected & 208828 \\
\hline Independent reflections & $7866\left[\mathrm{R}_{\text {int }}=0.1545, \mathrm{R}_{\text {sigma }}=0.0469\right]$ \\
\hline Data/restraints/parameters & $7866 / 0 / 396$ \\
\hline Goodness-of-fit on $\mathrm{F}^{2}$ & 1.066 \\
\hline Final $R$ indexes $[\mathrm{I}>=2 \sigma(\mathrm{I})]$ & $\mathrm{R}_{1}=0.0711, \mathrm{wR}_{2}=0.1652$ \\
\hline Final R indexes [all data] & $\mathrm{R}_{1}=0.1202, \mathrm{wR}_{2}=0.1907$ \\
\hline Largest diff. peak/hole / e $\AA^{-3}$ & $0.21 /-0.20$ \\
\hline Flack parameter & $0.4(3)$ \\
\hline
\end{tabular}




\section{Cyclic voltammograms of BODIPYs $2 e$ and 6}

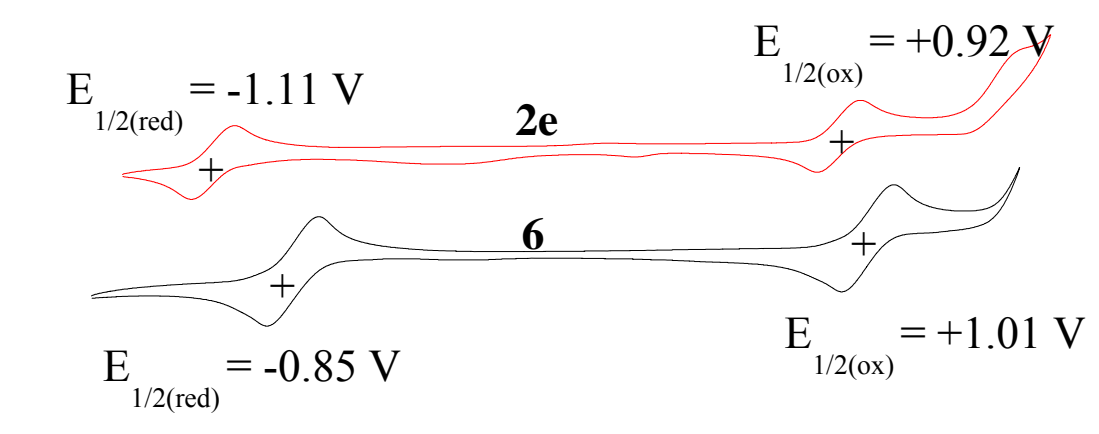

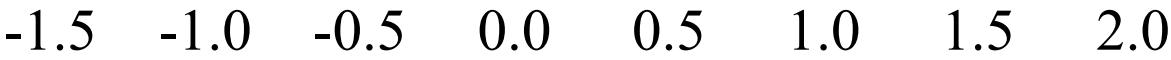 Potential (V) vs SCE}

Figure S2. Cyclic voltammograms of BODIPYs $2 \mathbf{e}$ and $6(1 \mathrm{mM})$ measured in dichloromethane containing $0.1 \mathrm{M} \mathrm{TBAPF}_{6}$ as the supporting electrolyte at room temperature.

Table S3. Electrochemical data acquired and HOMO-LUMO gaps determined from spectra of BODIPYs 2e and $\mathbf{6}$.

\begin{tabular}{|c|c|c|c|c|c|c|c|}
\hline dyes & $E_{1 / 2(\mathrm{red})}$ & $E_{1 / 2(\mathrm{ox})}$ & $E_{\text {red }}^{\text {onset }}$ & $E_{\mathrm{ox}}^{\mathrm{onset}}$ & $E_{\text {LUMO }}(\mathrm{eV})$ & $E_{\text {номо }}(\mathrm{eV})$ & $E_{g}^{1}(\mathrm{eV})$ \\
\hline $2 e$ & -1.11 & 0.92 & -1.17 & 0.96 & -3.23 & -5.36 & 2.13 \\
\hline 6 & -0.85 & 1.01 & -0.95 & 1.05 & -3.45 & -5.45 & 2.00 \\
\hline
\end{tabular}




\section{Photophysical properties}

Table S4. Photophysical properties of BODIPYs 2a-f, 3a-d, 4a-c, 5a-c and 6 in different solvents at room temperature

\begin{tabular}{|c|c|c|c|c|c|c|}
\hline dyes & solvents & $\lambda_{\max }(\mathrm{nm})$ & $\log \varepsilon_{\max }^{a}$ & $\lambda_{\mathrm{em}}(\mathrm{nm})$ & $\Phi^{\mathrm{b}}$ & Stokes-shift $\left(\mathrm{cm}^{-1}\right)$ \\
\hline \multirow{5}{*}{$2 a$} & Cyclohexane & 590 & 4.94 & 624 & 0.94 & 900 \\
\hline & Toluene & 592 & 4.81 & 629 & 0.75 & 1000 \\
\hline & $\mathrm{CH}_{2} \mathrm{Cl}_{2}$ & 585 & 4.80 & 626 & 0.74 & 1100 \\
\hline & THF & 587 & 4.80 & 627 & 0.90 & 1100 \\
\hline & $\mathrm{MeCN}$ & 578 & 4.74 & 623 & 0.87 & 1200 \\
\hline \multirow{5}{*}{$2 \mathbf{b}$} & Cyclohexane & 602 & 4.70 & 639 & 0.77 & 1000 \\
\hline & Toluene & 606 & 4.70 & 645 & 0.78 & 1000 \\
\hline & $\mathrm{CH}_{2} \mathrm{Cl}_{2}$ & 599 & 4.65 & 644 & 0.74 & 1200 \\
\hline & THF & 602 & 4.67 & 628 & 0.96 & 700 \\
\hline & $\mathrm{MeCN}$ & 592 & 4.59 & 643 & 0.62 & 1300 \\
\hline \multirow{5}{*}{ 2c } & Cyclohexane & 596 & 4.94 & 633 & 0.86 & 1000 \\
\hline & Toluene & 596 & 4.90 & 636 & 0.78 & 1100 \\
\hline & $\mathrm{CH}_{2} \mathrm{Cl}_{2}$ & 588 & 4.87 & 632 & 0.83 & 1200 \\
\hline & THF & 592 & 4.88 & 634 & 0.76 & 1100 \\
\hline & $\mathrm{MeCN}$ & 581 & 4.85 & 629 & 0.65 & 1300 \\
\hline \multirow{5}{*}{ 2d } & Cyclohexane & 626 & 4.93 & 670 & 0.33 & 1000 \\
\hline & Toluene & 629 & 4.88 & 677 & 0.16 & 1100 \\
\hline & $\mathrm{CH}_{2} \mathrm{Cl}_{2}$ & 617 & 4.87 & 651 & 0.05 & 900 \\
\hline & THF & 621 & 4.87 & 662 & 0.08 & 1000 \\
\hline & $\mathrm{MeCN}$ & 608 & 4.82 & 628 & 0.02 & 500 \\
\hline \multirow{5}{*}{$2 \mathbf{e}$} & Cyclohexane & 621 & 4.77 & 666 & 0.64 & 1100 \\
\hline & Toluene & 625 & 4.73 & 677 & 0.51 & 1200 \\
\hline & $\mathrm{CH}_{2} \mathrm{Cl}_{2}$ & 616 & 4.69 & 672 & 0.42 & 1400 \\
\hline & THF & 621 & 4.71 & 674 & 0.42 & 1300 \\
\hline & $\mathrm{MeCN}$ & 608 & 4.64 & 673 & 0.24 & 1600 \\
\hline \multirow{5}{*}{$2 f$} & Cyclohexane & 579 & 4.99 & 625 & 0.41 & 1300 \\
\hline & Toluene & 581 & 4.99 & 628 & 0.44 & 1300 \\
\hline & $\mathrm{CH}_{2} \mathrm{Cl}_{2}$ & 573 & 4.93 & 627 & 0.30 & 1500 \\
\hline & THF & 577 & 4.97 & 626 & 0.33 & 1400 \\
\hline & $\mathrm{MeCN}$ & 559 & 4.92 & 620 & 0.24 & 1800 \\
\hline \multirow{5}{*}{ 3a } & Cyclohexane & 674 & 5.27 & 688 & 0.64 & 300 \\
\hline & Toluene & 680 & 5.22 & 697 & 0.51 & 400 \\
\hline & $\mathrm{CH}_{2} \mathrm{Cl}_{2}$ & 673 & 5.19 & 693 & 0.55 & 500 \\
\hline & THF & 673 & 5.15 & 691 & 0.55 & 400 \\
\hline & $\mathrm{MeCN}$ & 666 & 5.13 & 688 & 0.55 & 500 \\
\hline
\end{tabular}




\begin{tabular}{|c|c|c|c|c|c|c|}
\hline \multirow{5}{*}{$3 \mathbf{b}$} & Cyclohexane & 693 & 5.34 & 707 & 0.30 & 300 \\
\hline & Toluene & 698 & 5.24 & 715 & 0.29 & 300 \\
\hline & $\mathrm{CH}_{2} \mathrm{Cl}_{2}$ & 693 & 5.20 & 715 & 0.25 & 400 \\
\hline & THF & 692 & 5.20 & 711 & 0.25 & 400 \\
\hline & $\mathrm{MeCN}$ & 686 & 5.17 & 711 & 0.24 & 500 \\
\hline \multirow{5}{*}{$3 c$} & Cyclohexane & 678 & 5.16 & 710 & 0.08 & 700 \\
\hline & Toluene & 682 & 5.16 & 717 & $<0.01$ & 700 \\
\hline & $\mathrm{CH}_{2} \mathrm{Cl}_{2}$ & 675 & 5.10 & 713 & $<0.01$ & 800 \\
\hline & THF & 676 & 5.10 & 713 & $<0.01$ & 800 \\
\hline & $\mathrm{MeCN}$ & 666 & 5.08 & 711 & $<0.01$ & 1000 \\
\hline \multirow{5}{*}{ 3d } & Cyclohexane & 733 & 5.30 & 749 & 0.10 & 300 \\
\hline & Toluene & 740 & 5.29 & 767 & $<0.01$ & 500 \\
\hline & $\mathrm{CH}_{2} \mathrm{Cl}_{2}$ & 727 & 5.19 & 771 & $<0.01$ & 800 \\
\hline & THF & 730 & 5.25 & 763 & $<0.01$ & 600 \\
\hline & $\mathrm{MeCN}$ & 718 & 5.17 & 755 & $<0.01$ & 700 \\
\hline \multirow{5}{*}{$4 a$} & Cyclohexane & 602 & 4.82 & 643 & 0.33 & 1100 \\
\hline & Toluene & 605 & 4.80 & 649 & 0.43 & 1100 \\
\hline & $\mathrm{CH}_{2} \mathrm{Cl}_{2}$ & 598 & 4.77 & 649 & 0.30 & 1300 \\
\hline & THF & 601 & 4.80 & 649 & 0.28 & 1200 \\
\hline & $\mathrm{MeCN}$ & 590 & 4.73 & 647 & 0.29 & 1500 \\
\hline \multirow{5}{*}{$4 a-B r$} & Cyclohexane & 577 & 4.95 & 614 & 0.13 & 1000 \\
\hline & Toluene & 581 & 4.92 & 618 & 0.10 & 1000 \\
\hline & $\mathrm{CH}_{2} \mathrm{Cl}_{2}$ & 572 & 4.90 & 619 & 0.09 & 1300 \\
\hline & THF & 577 & 4.91 & 617 & 0.11 & 1100 \\
\hline & $\mathrm{MeCN}$ & 559 & 4.89 & 613 & 0.03 & 1600 \\
\hline \multirow{5}{*}{$4 b$} & Cyclohexane & 589 & 4.84 & 634 & 0.32 & 1000 \\
\hline & Toluene & 591 & 4.83 & 639 & 0.57 & 1300 \\
\hline & $\mathrm{CH}_{2} \mathrm{Cl}_{2}$ & 579 & 4.77 & 636 & 0.45 & 1500 \\
\hline & $\mathrm{THF}$ & 585 & 4.65 & 637 & 0.30 & 1400 \\
\hline & $\mathrm{MeCN}$ & 563 & 4.69 & 629 & 0.25 & 1900 \\
\hline \multirow{5}{*}{$4 c$} & Cyclohexane & 591 & 4.85 & 636 & 0.44 & 1200 \\
\hline & Toluene & 593 & 4.84 & 640 & 0.54 & 1200 \\
\hline & $\mathrm{CH}_{2} \mathrm{Cl}_{2}$ & 583 & 4.77 & 640 & 0.58 & 1500 \\
\hline & THF & 587 & 4.82 & 638 & 0.45 & 1400 \\
\hline & $\mathrm{MeCN}$ & 569 & 4.75 & 632 & 0.38 & 1800 \\
\hline \multirow{5}{*}{$5 a$} & Cyclohexane & 693 & 5.29 & 709 & 0.66 & 300 \\
\hline & Toluene & 694 & 5.22 & 713 & 0.68 & 400 \\
\hline & $\mathrm{CH}_{2} \mathrm{Cl}_{2}$ & 691 & 5.19 & 716 & 0.62 & 500 \\
\hline & THF & 689 & 5.17 & 713 & 0.47 & 500 \\
\hline & $\mathrm{MeCN}$ & 683 & 5.11 & 712 & 0.49 & 600 \\
\hline \multirow{4}{*}{$5 a-B r$} & Cyclohexane & 689 & 5.18 & 711 & 0.03 & 400 \\
\hline & Toluene & 691 & 5.11 & 715 & 0.03 & 500 \\
\hline & $\mathrm{CH}_{2} \mathrm{Cl}_{2}$ & 689 & 5.08 & 717 & 0.03 & 600 \\
\hline & THF & 686 & 5.08 & 715 & 0.02 & 600 \\
\hline
\end{tabular}




\begin{tabular}{|c|c|c|c|c|c|c|}
\hline & $\mathrm{MeCN}$ & 682 & 5.04 & 714 & 0.02 & 700 \\
\hline \multirow{5}{*}{$5 \mathbf{b}$} & Cyclohexane & 687 & 4.89 & 711 & 0.44 & 500 \\
\hline & Toluene & 687 & 4.83 & 714 & 0.46 & 500 \\
\hline & $\mathrm{CH}_{2} \mathrm{Cl}_{2}$ & 683 & 4.83 & 712 & 0.45 & 600 \\
\hline & $\mathrm{THF}$ & 683 & 4.80 & 712 & 0.45 & 600 \\
\hline & $\mathrm{MeCN}$ & 677 & 4.72 & 706 & 0.27 & 600 \\
\hline \multirow{5}{*}{$5 c$} & Cyclohexane & 680 & 4.98 & 727 & 0.62 & 1000 \\
\hline & Toluene & 682 & 4.95 & 730 & 0.43 & 1000 \\
\hline & $\mathrm{CH}_{2} \mathrm{Cl}_{2}$ & 677 & 4.96 & 737 & 0.54 & 1000 \\
\hline & THF & 677 & 4.94 & 737 & 0.50 & 1000 \\
\hline & $\mathrm{MeCN}$ & 670 & 4.94 & 721 & 0.52 & 1100 \\
\hline \multirow{5}{*}{6} & Cyclohexane & 669 & 4.98 & 700 & 0.63 & 700 \\
\hline & Toluene & 675 & 4.93 & 712 & 0.54 & 800 \\
\hline & $\mathrm{CH}_{2} \mathrm{Cl}_{2}$ & 664 & 4.88 & 711 & 0.53 & 1000 \\
\hline & THF & 670 & 4.89 & 712 & 0.50 & 900 \\
\hline & $\mathrm{MeCN}$ & 660 & 4.82 & 712 & 0.33 & 400 \\
\hline \multicolumn{7}{|c|}{$\begin{array}{l}{ }^{a} \text { Molar extinction coefficients are in the maximum of the highest peak. the } \\
\text { fluorescence quantum yields }(\Phi) \text { of } \mathbf{2 a - f}, \mathbf{4 a - c} \text { were calculated using Cresyl violet } \\
\text { perchlorate in anhydrous methanol }(\Phi=0.54) \text { as the standard. the fluorescence } \\
\text { quantum yields }(\Phi) \text { of } \mathbf{3 a - d}, \mathbf{5 a - c} \mathbf{6} \text { were calculated using } \\
\text { 1,7-diphenyl-3,5-di }(p \text {-methoxyphenyl)-azadipyrromethene in trichloromethane }(\Phi= \\
\text { 0.36) as the standard. }\end{array}$} \\
\hline
\end{tabular}



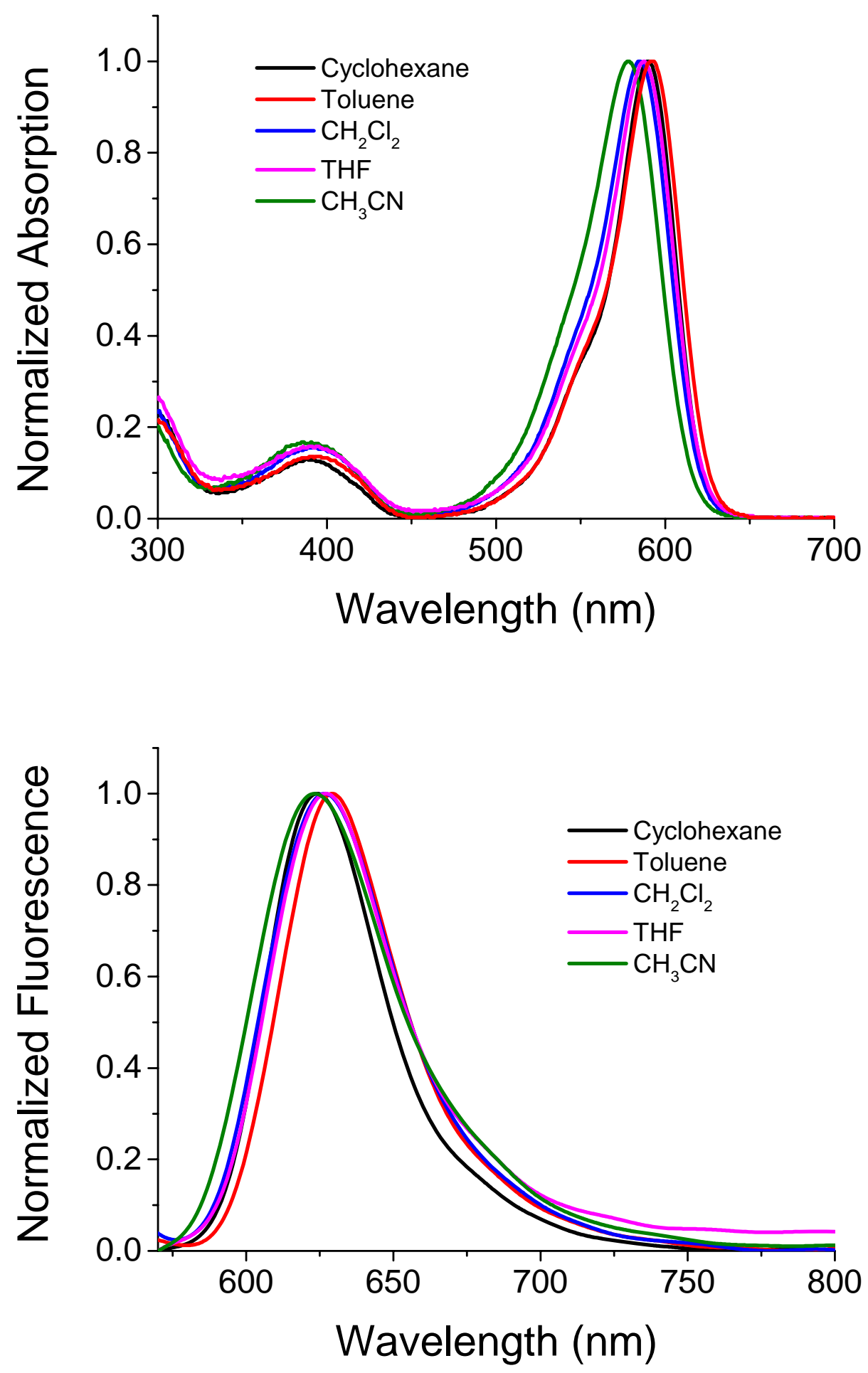

Figure S3. Normalized absorption (top) and emission (bottom) spectra of 2a recorded in different solvents. Excited at $560 \mathrm{~nm}$. 

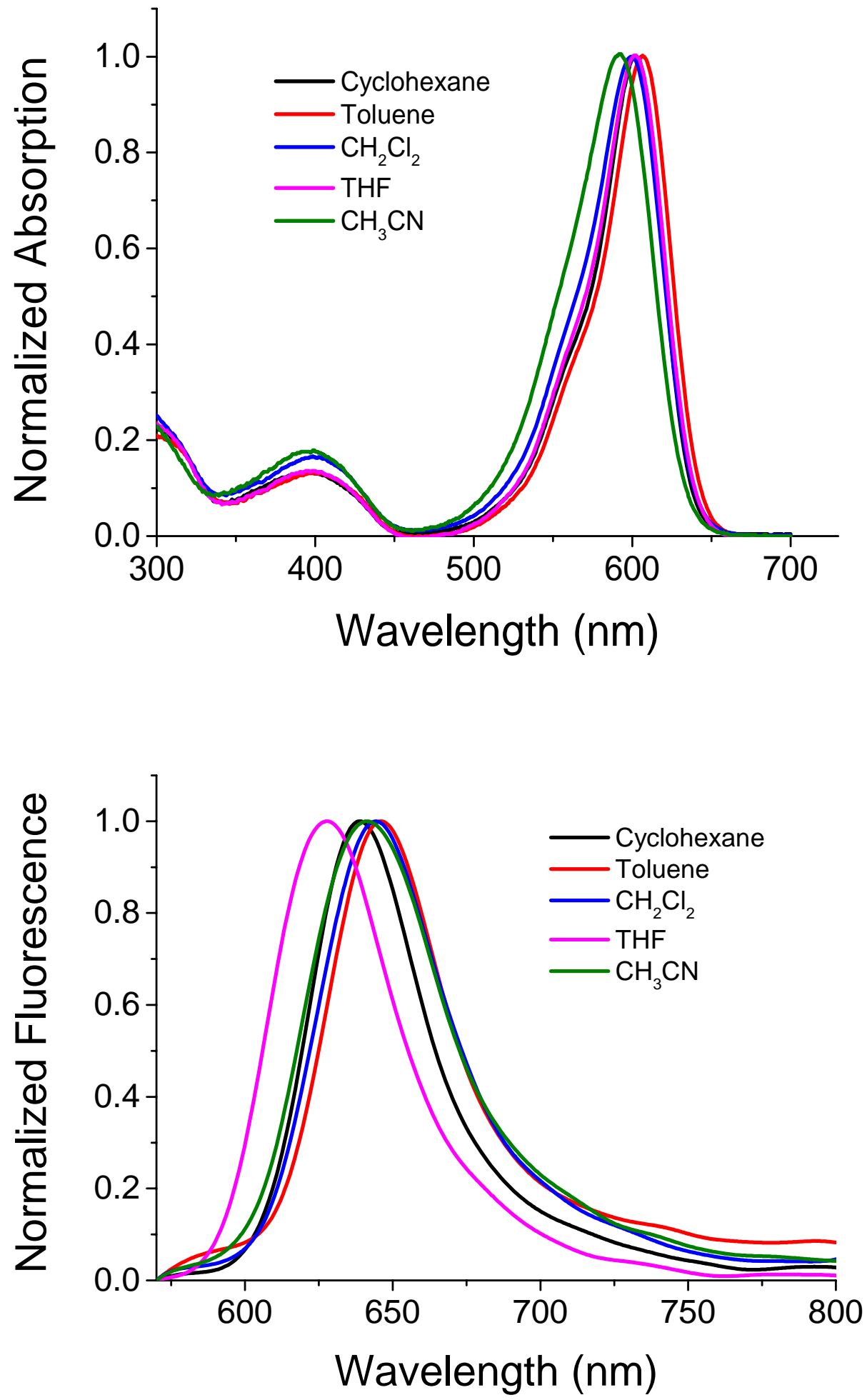

Figure S4. Normalized absorption (top) and emission (bottom) spectra of $\mathbf{2} \mathbf{b}$ recorded in different solvents. Excited at $560 \mathrm{~nm}$. 

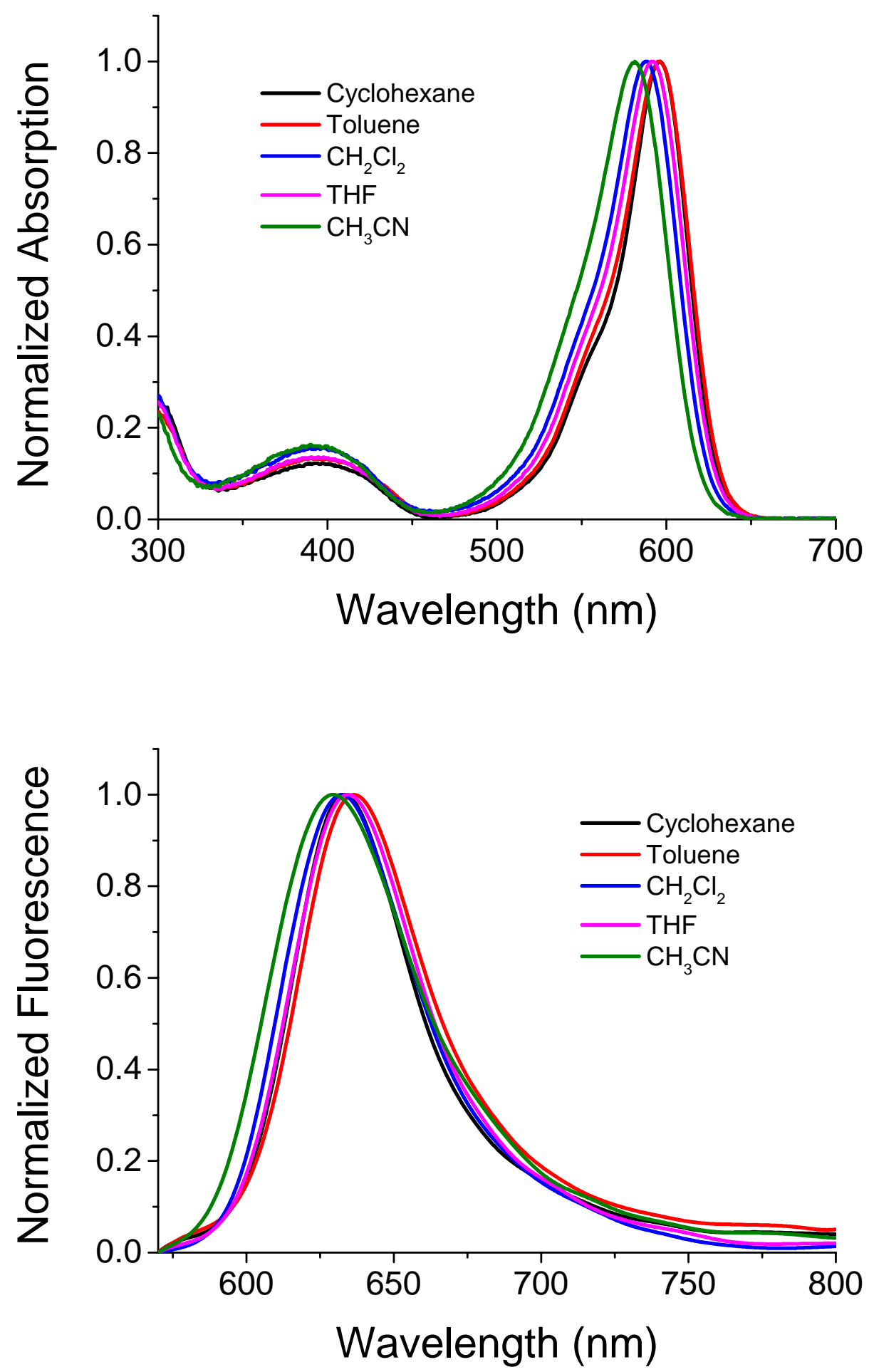

Figure S5. Normalized absorption (top) and emission (bottom) spectra of 2c recorded in different solvents. Excited at $560 \mathrm{~nm}$. 

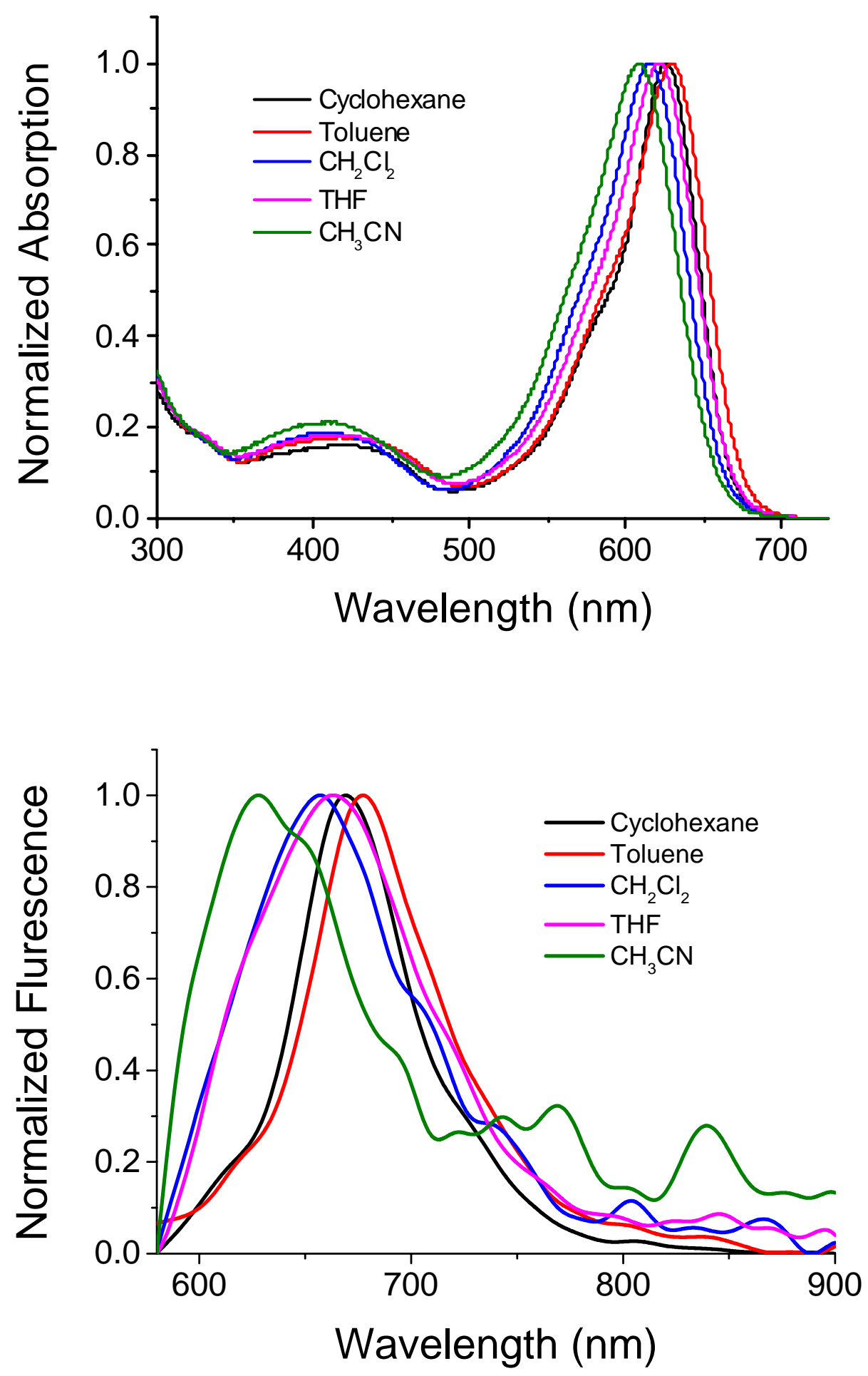

Figure S6. Normalized absorption (top) and emission (bottom) spectra of 2d recorded in different solvents. Excited at $570 \mathrm{~nm}$. 

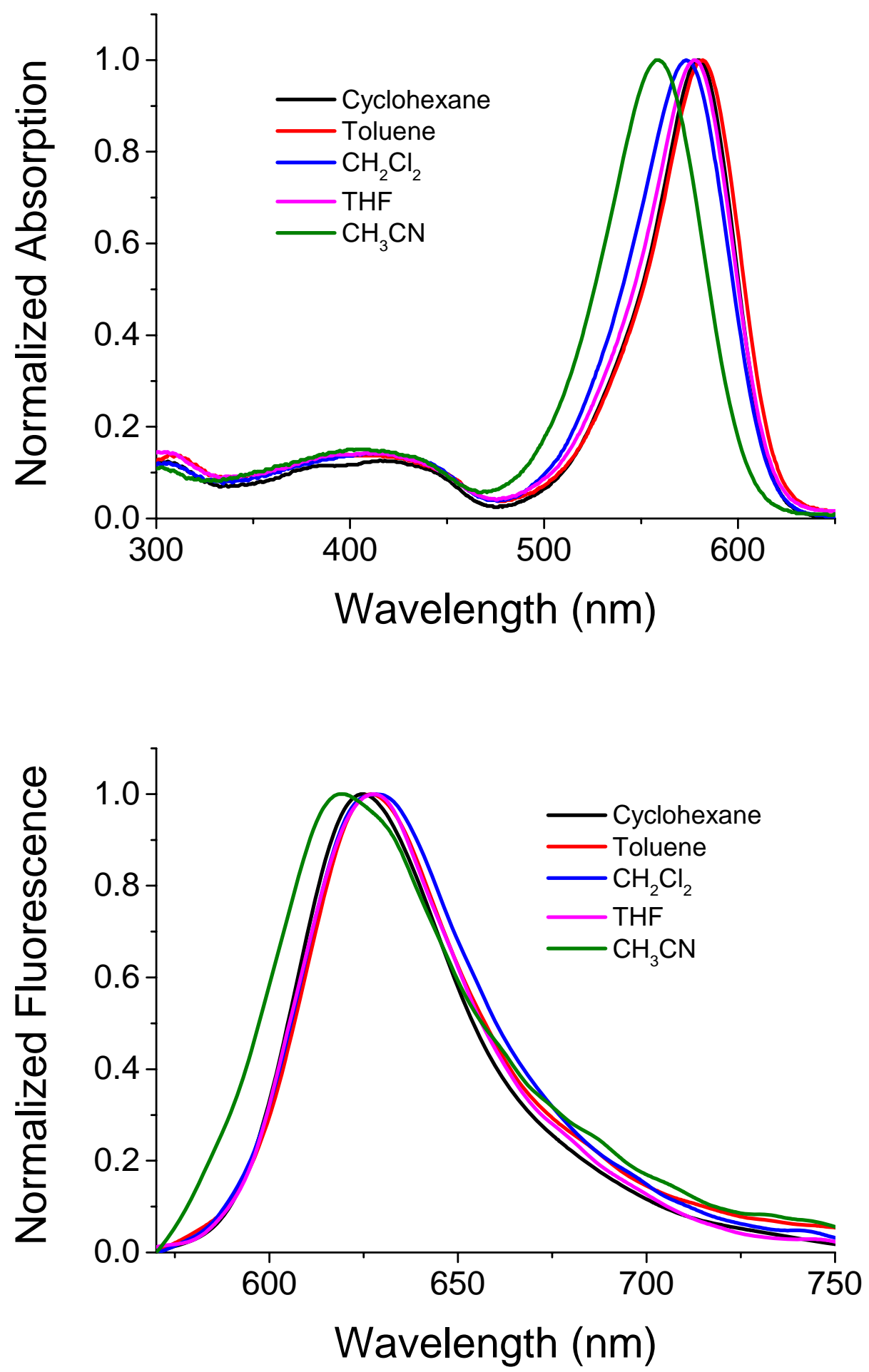

Figure S7. Normalized absorption (top) and emission (bottom) spectra of 2e recorded in different solvents. Excited at $560 \mathrm{~nm}$. 

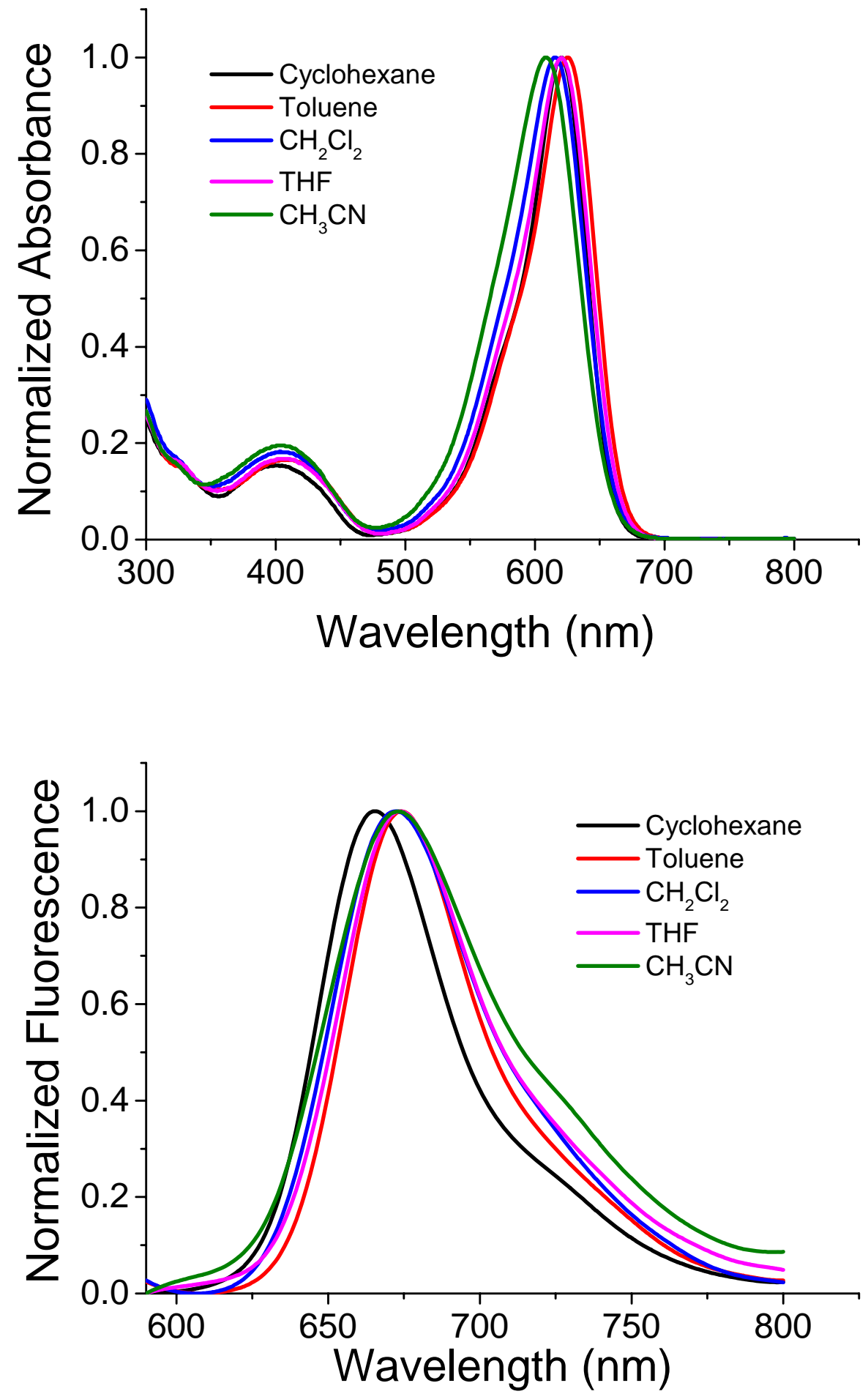

Figure S8. Normalized Absorption (top) and emission (bottom) spectra of $\mathbf{2 f}$ recorded in different solvents. Excited at $580 \mathrm{~nm}$. 

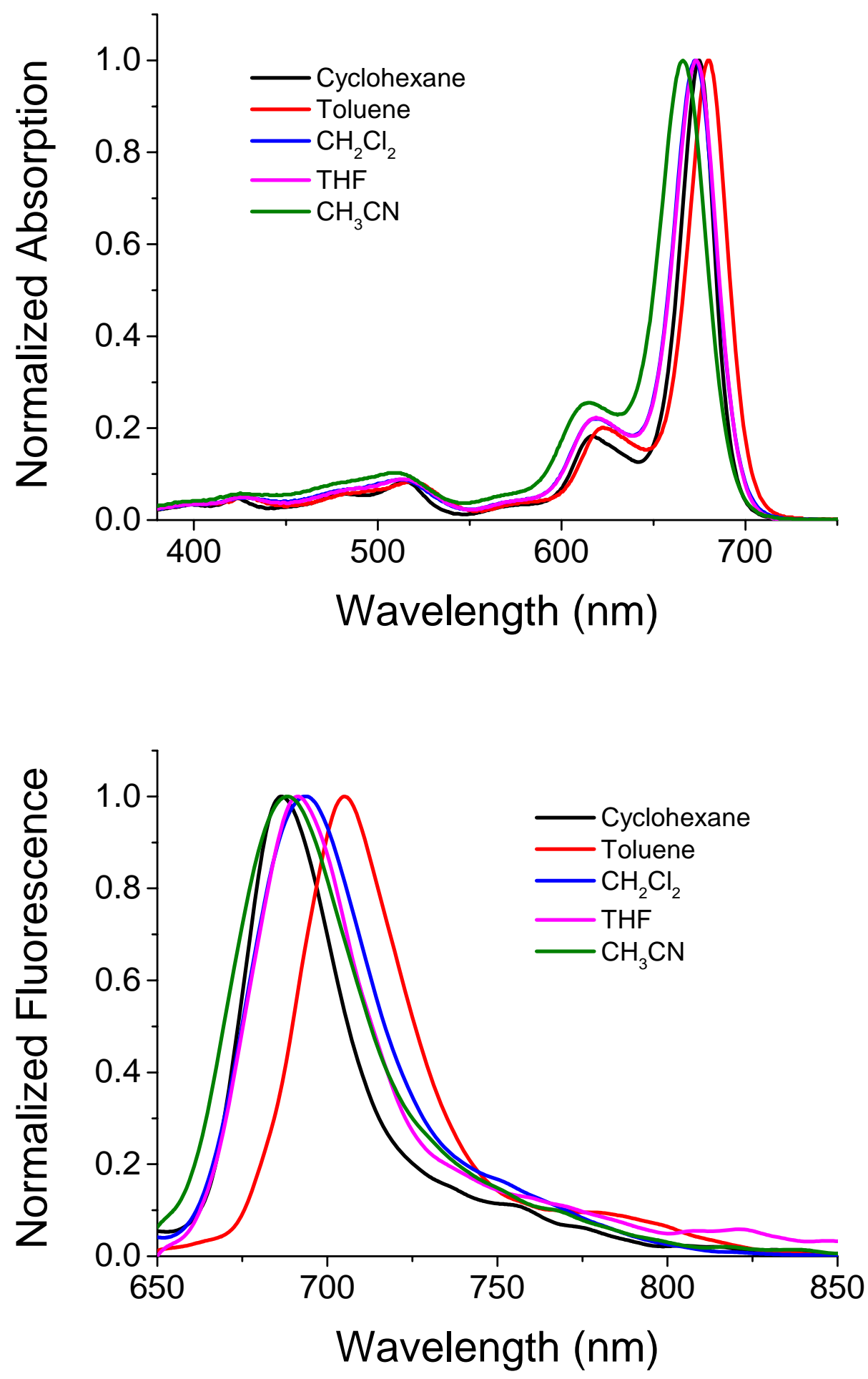

Figure S9. Normalized absorption (top) and emission (bottom) spectra of 3a recorded in different solvents. Excited at $640 \mathrm{~nm}$. 

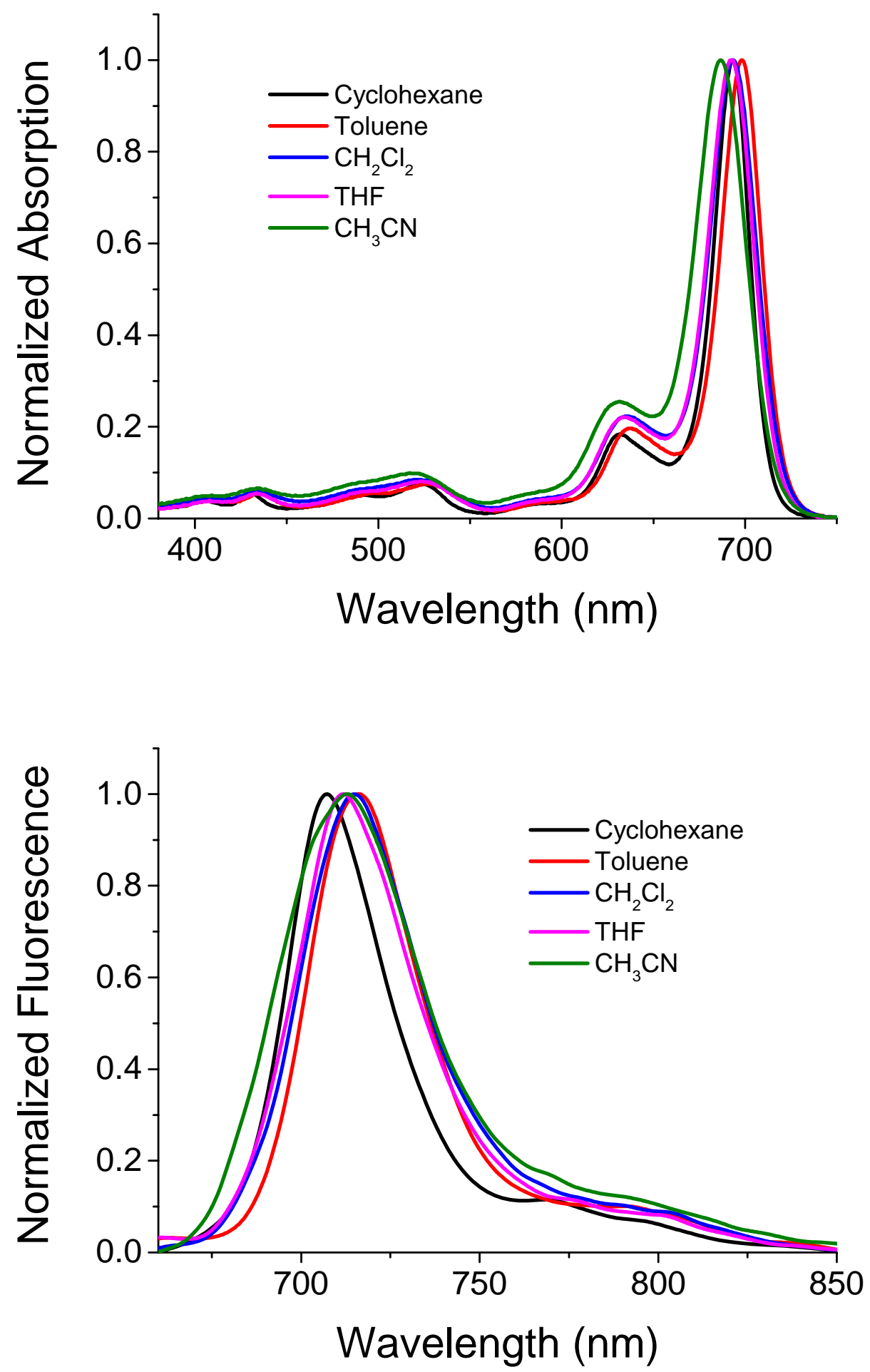

Figure S10. Normalized absorption (top) and emission (bottom) spectra of $\mathbf{3 b}$ recorded in different solvents. Excited at $650 \mathrm{~nm}$. 

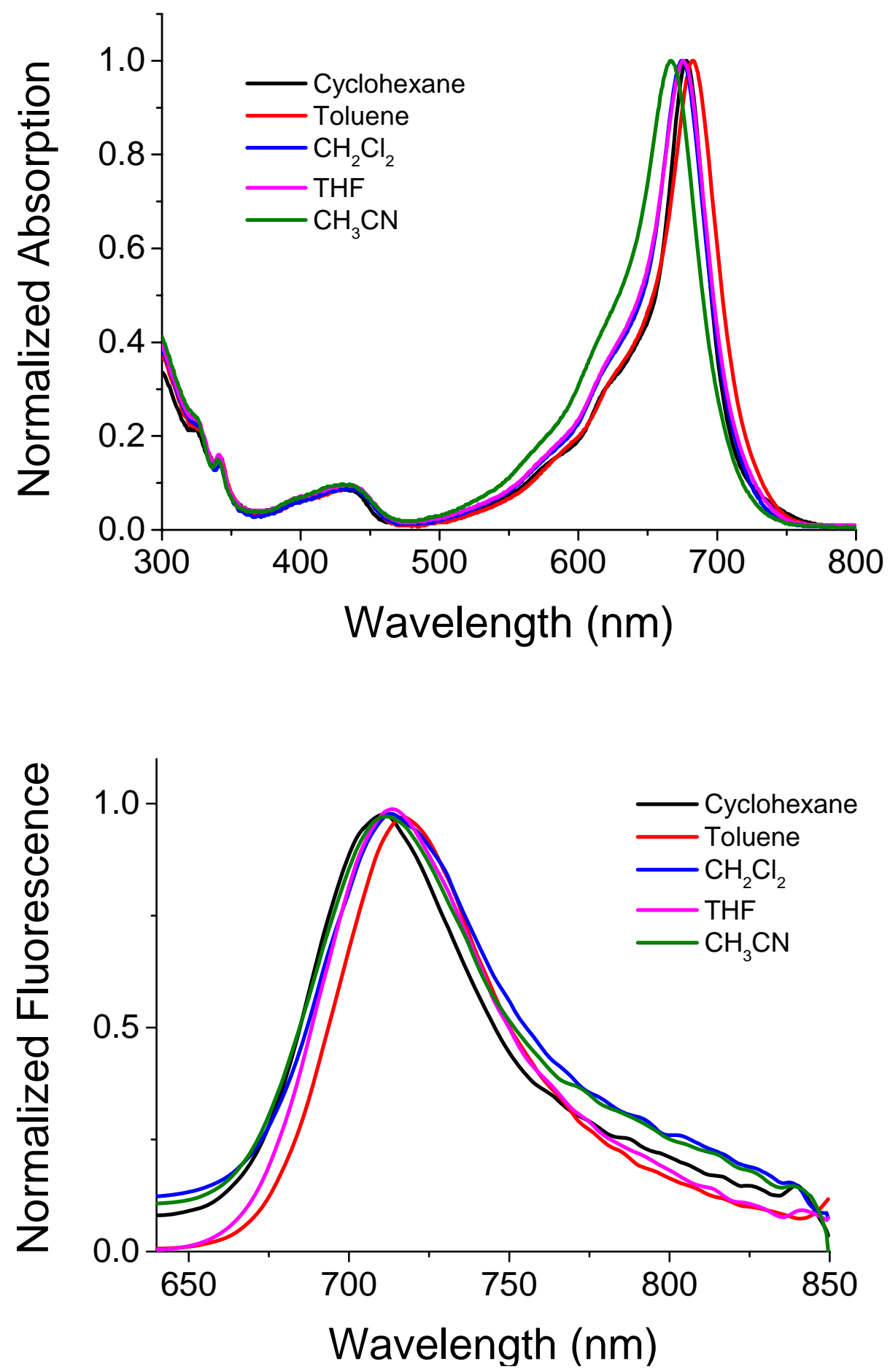

Figure S11. Normalized absorption (top) and emission (bottom) spectra of 3c recorded in different solvents. Excited at $630 \mathrm{~nm}$. 

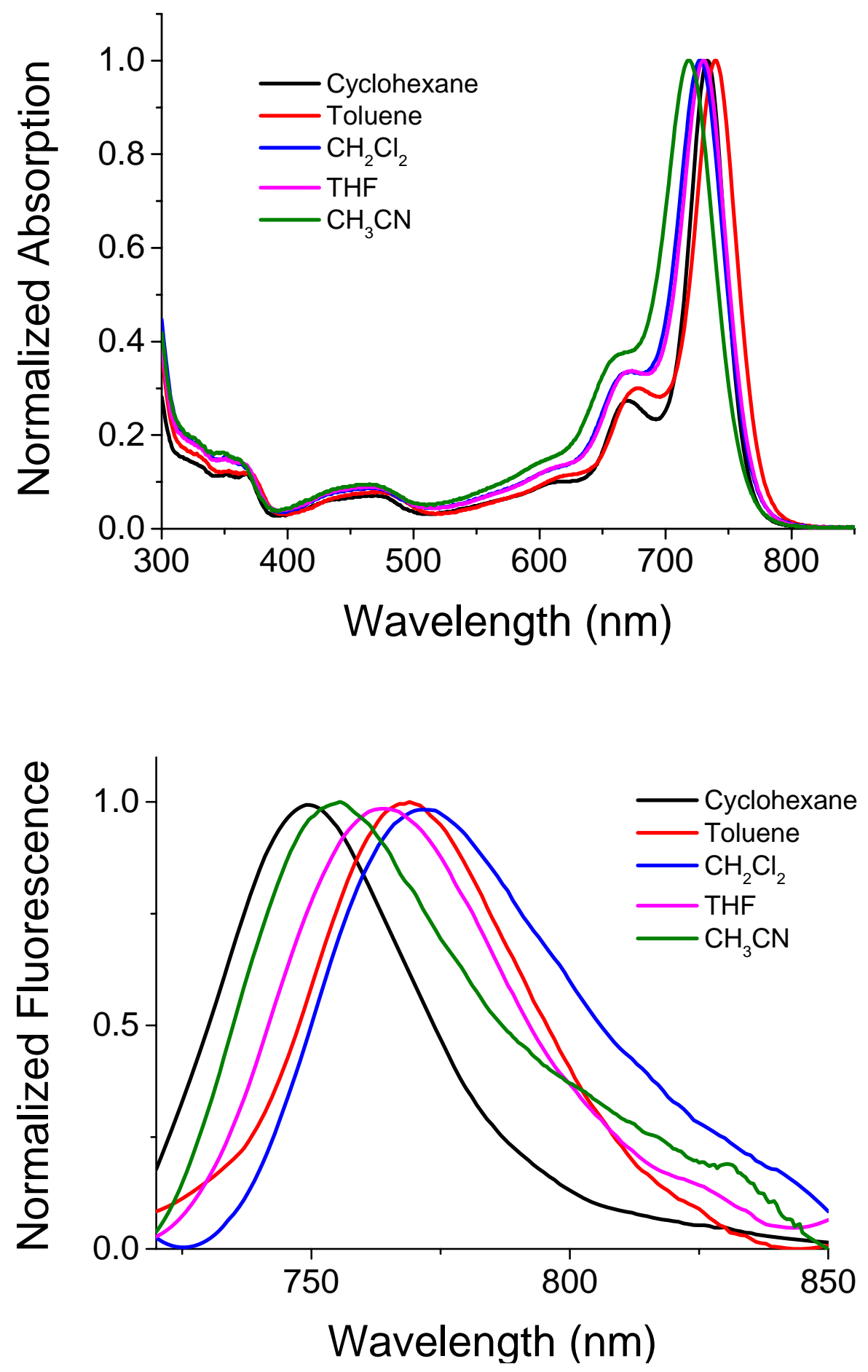

Figure S12. Normalized absorption (top) and emission (bottom) spectra of 3d recorded in different solvents. Excited at $700 \mathrm{~nm}$. 

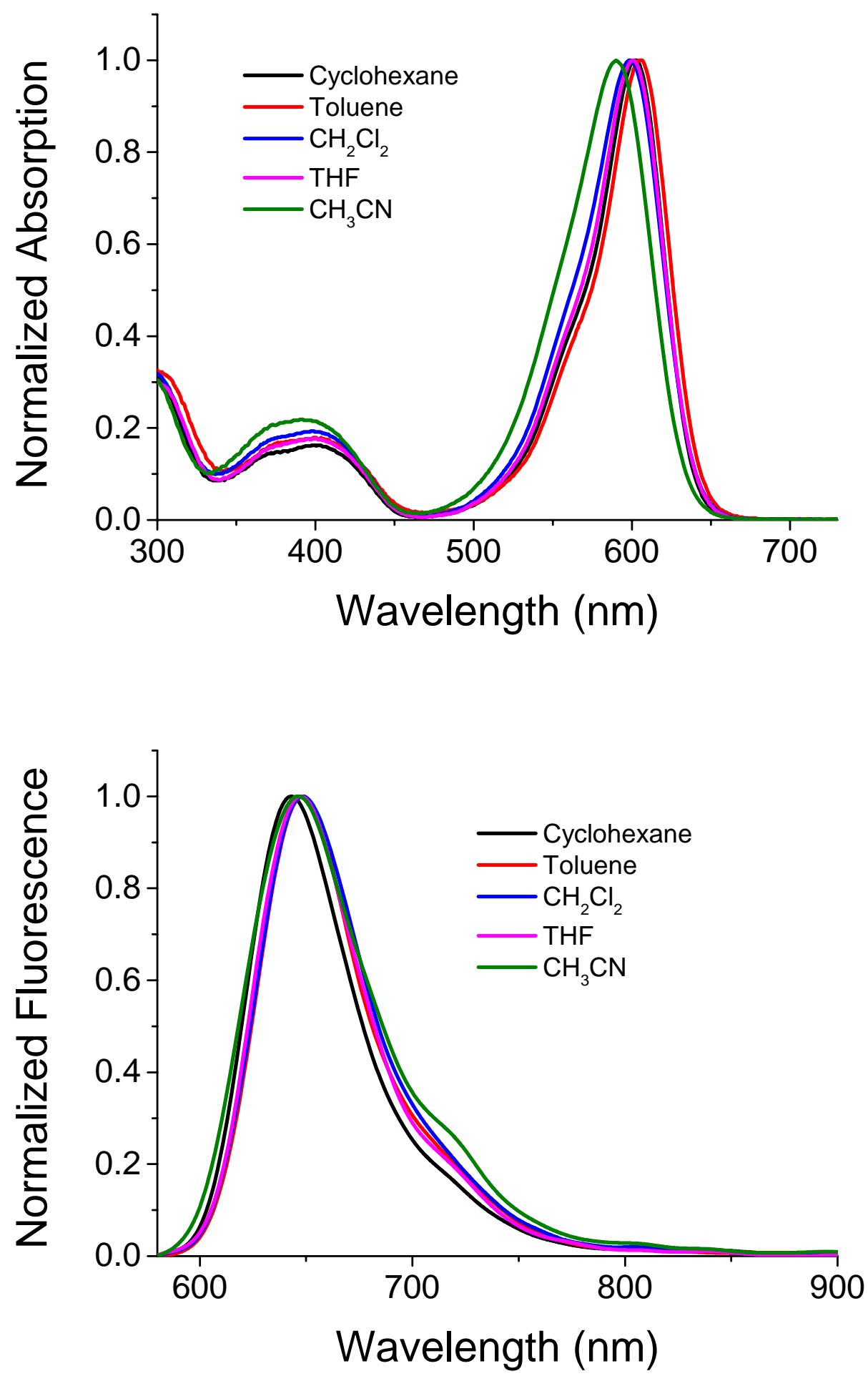

Figure S13. Normalized absorption (top) and emission (bottom) spectra of 4a recorded in different solvents. Excited at $570 \mathrm{~nm}$. 

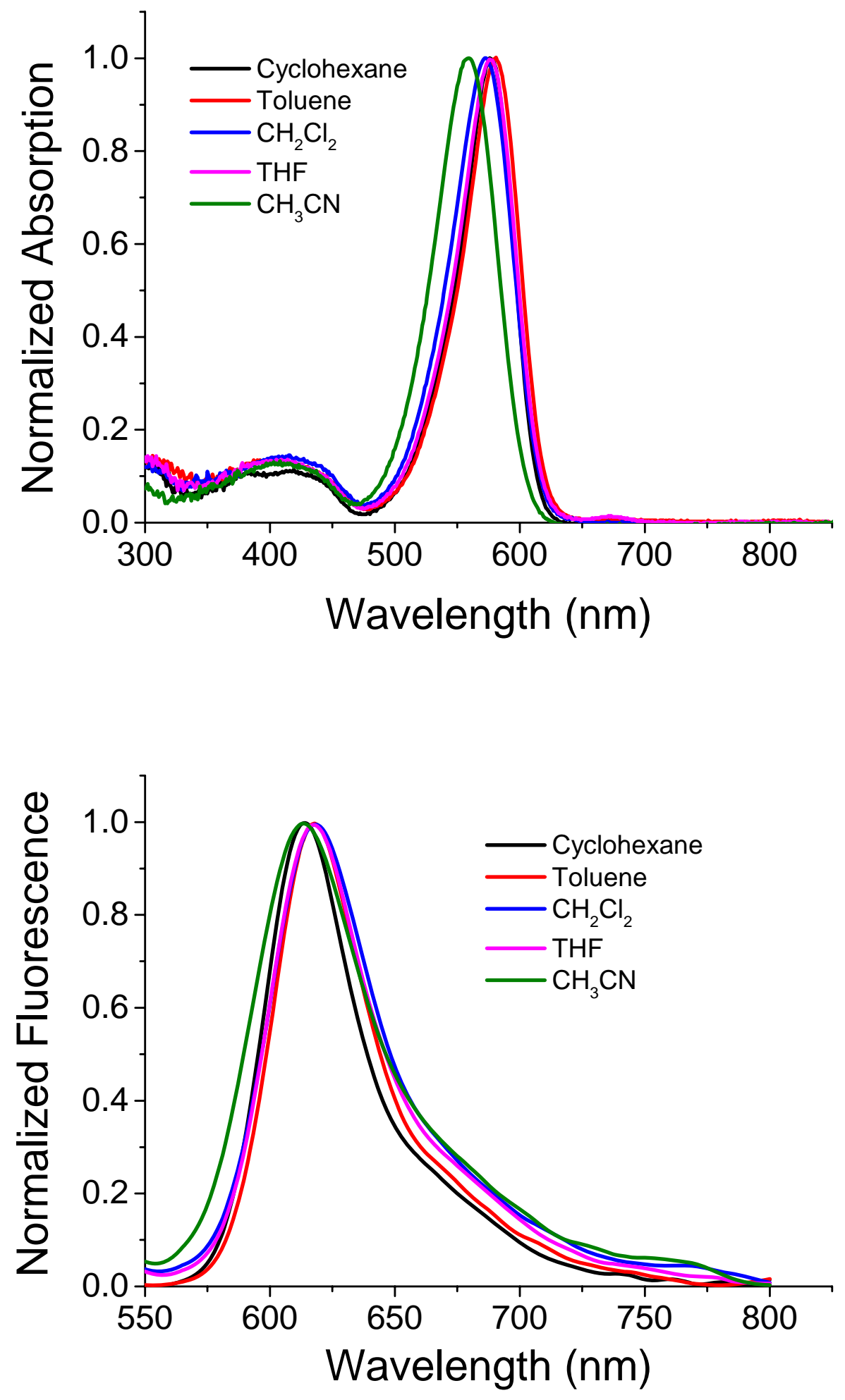

Figure S14. Normalized absorption (top) and emission (bottom) spectra of $\mathbf{4 a - B r}$ recorded in different solvents. Excited at $540 \mathrm{~nm}$. 

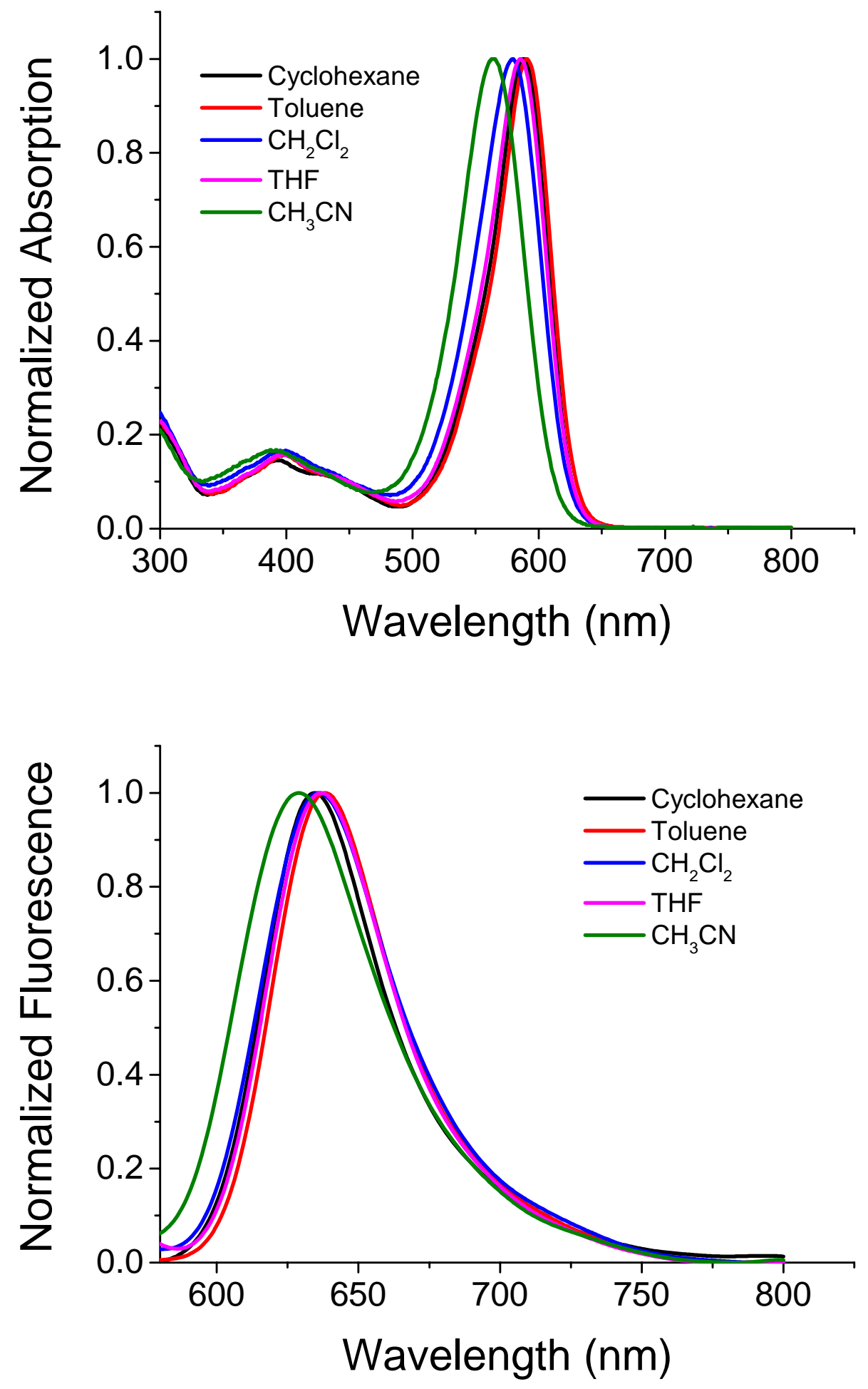

Figure S15. Normalized absorption (top) and emission (bottom) spectra of $\mathbf{4 b}$ recorded in different solvents. Excited at $570 \mathrm{~nm}$. 

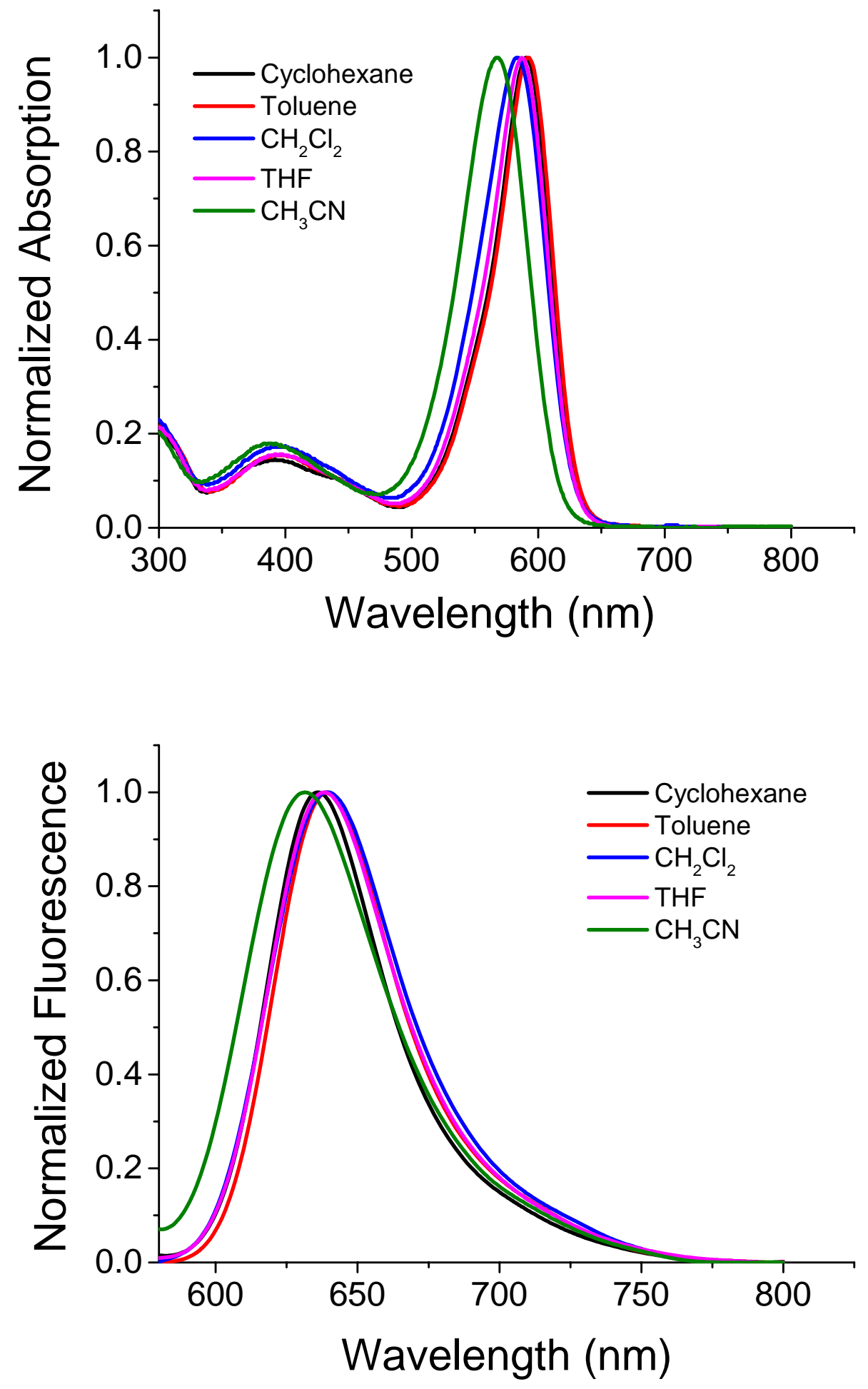

Figure S16. Normalized absorption (top) and emission (bottom) spectra of 4c recorded in different solvents. Excited at $570 \mathrm{~nm}$. 

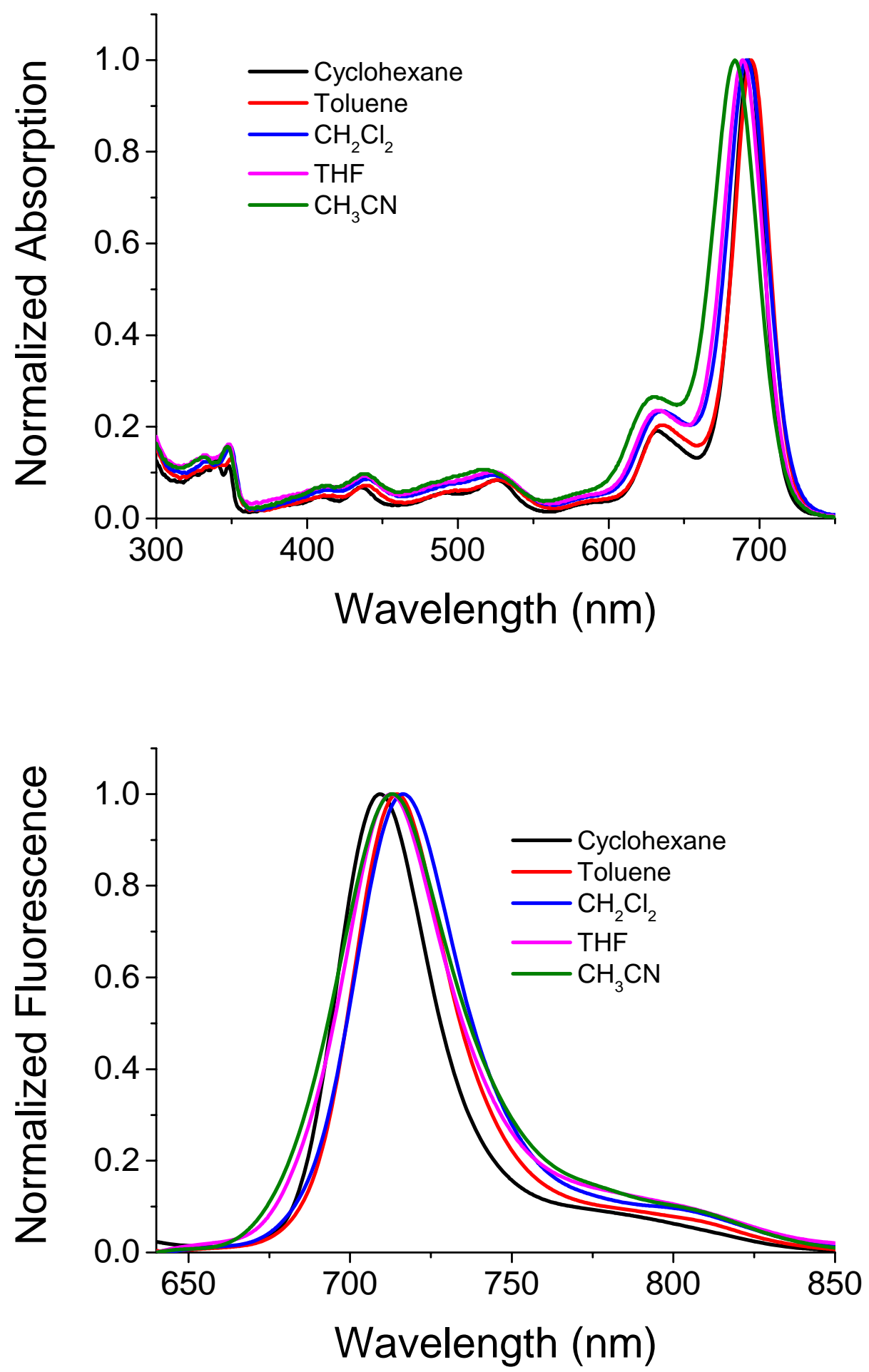

Figure S17. Normalized absorption (top) and emission (bottom) spectra of 5a recorded in different solvents. Excited at $630 \mathrm{~nm}$. 

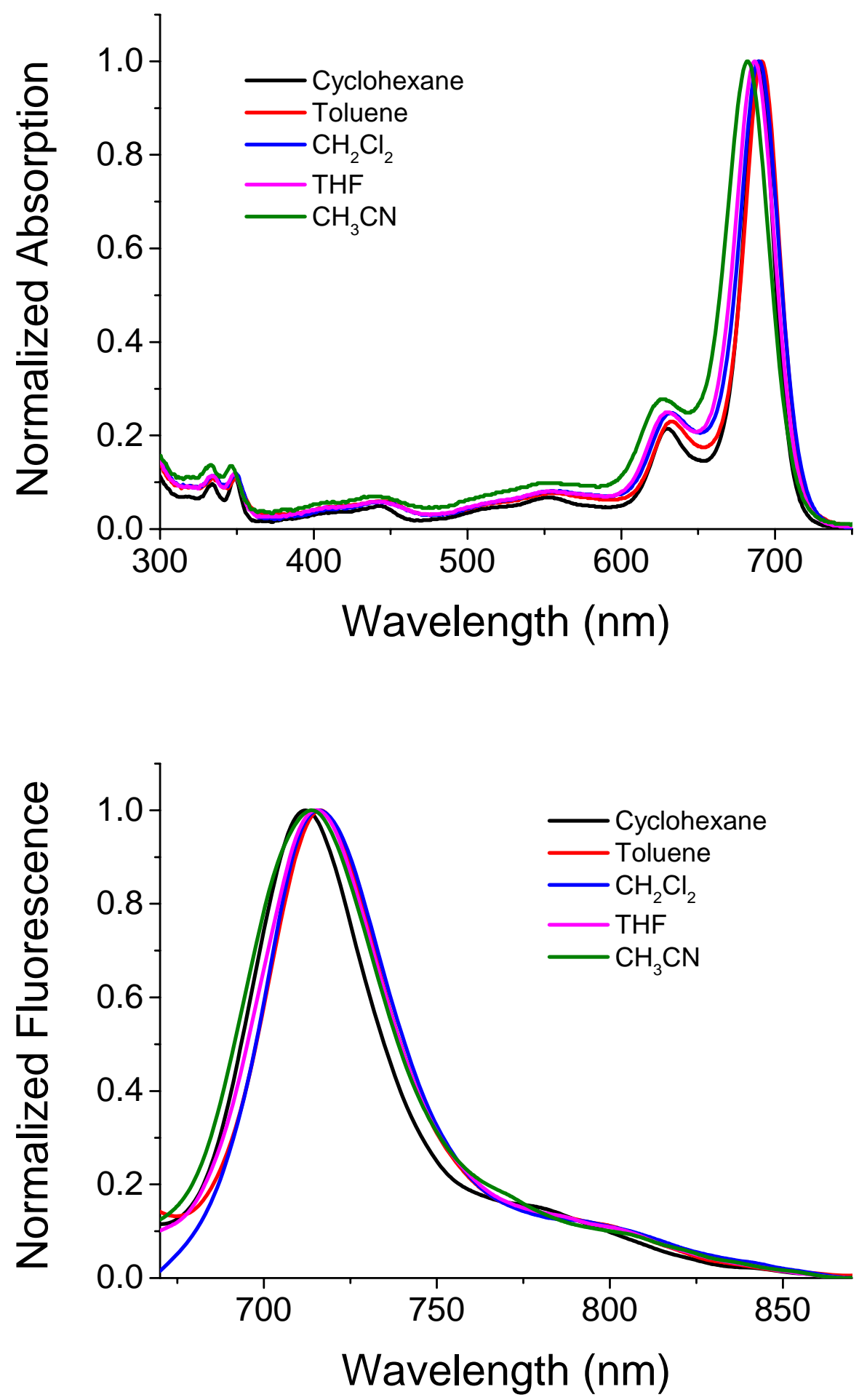

Figure S18. Normalized absorption (top) and emission (bottom) spectra of 5a-Br recorded in different solvents. Excited at $660 \mathrm{~nm}$. 

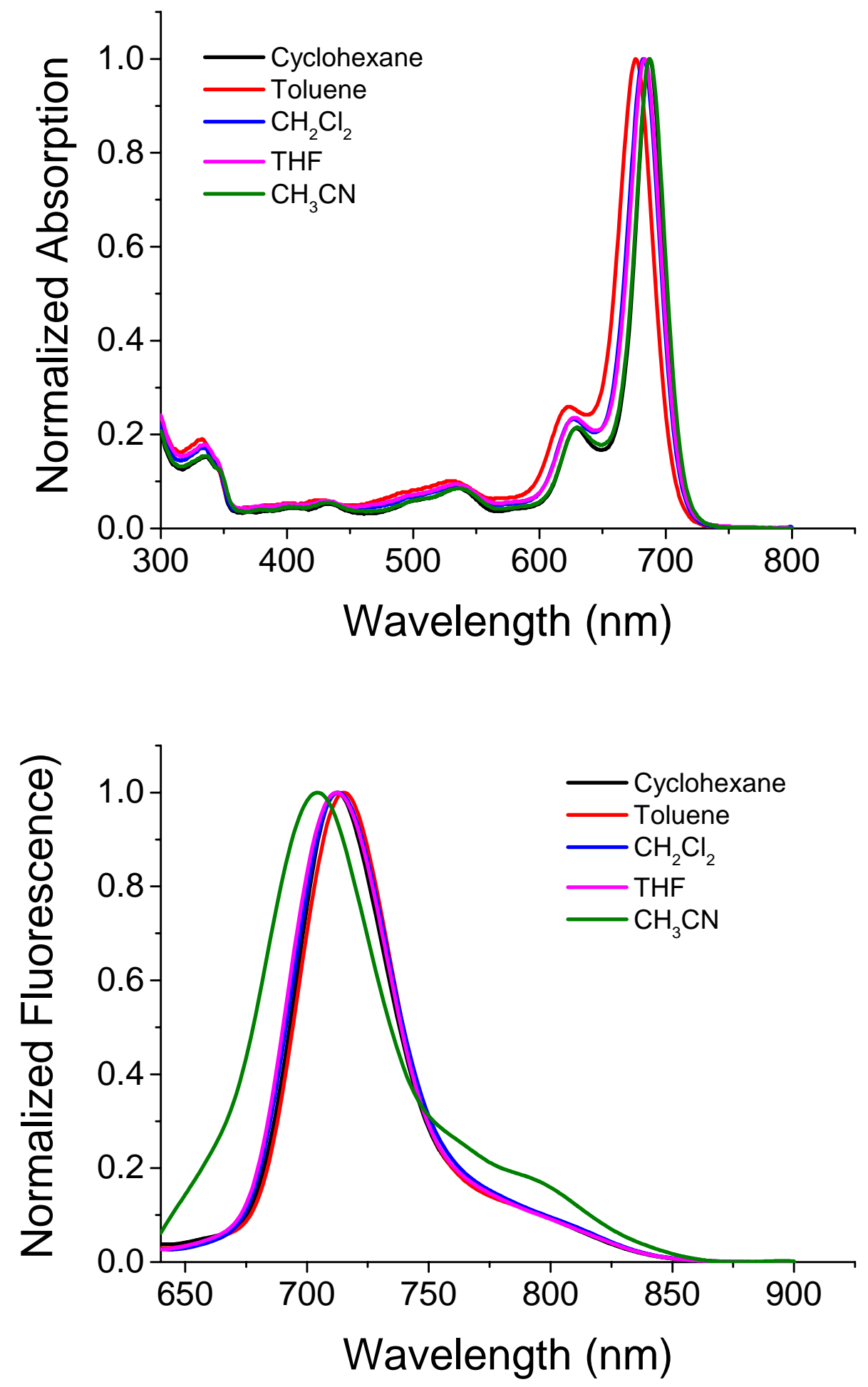

Figure S19. Normalized absorption (top) and emission (bottom) spectra of $\mathbf{5 b}$ recorded in different solvents. Excited at $630 \mathrm{~nm}$. 

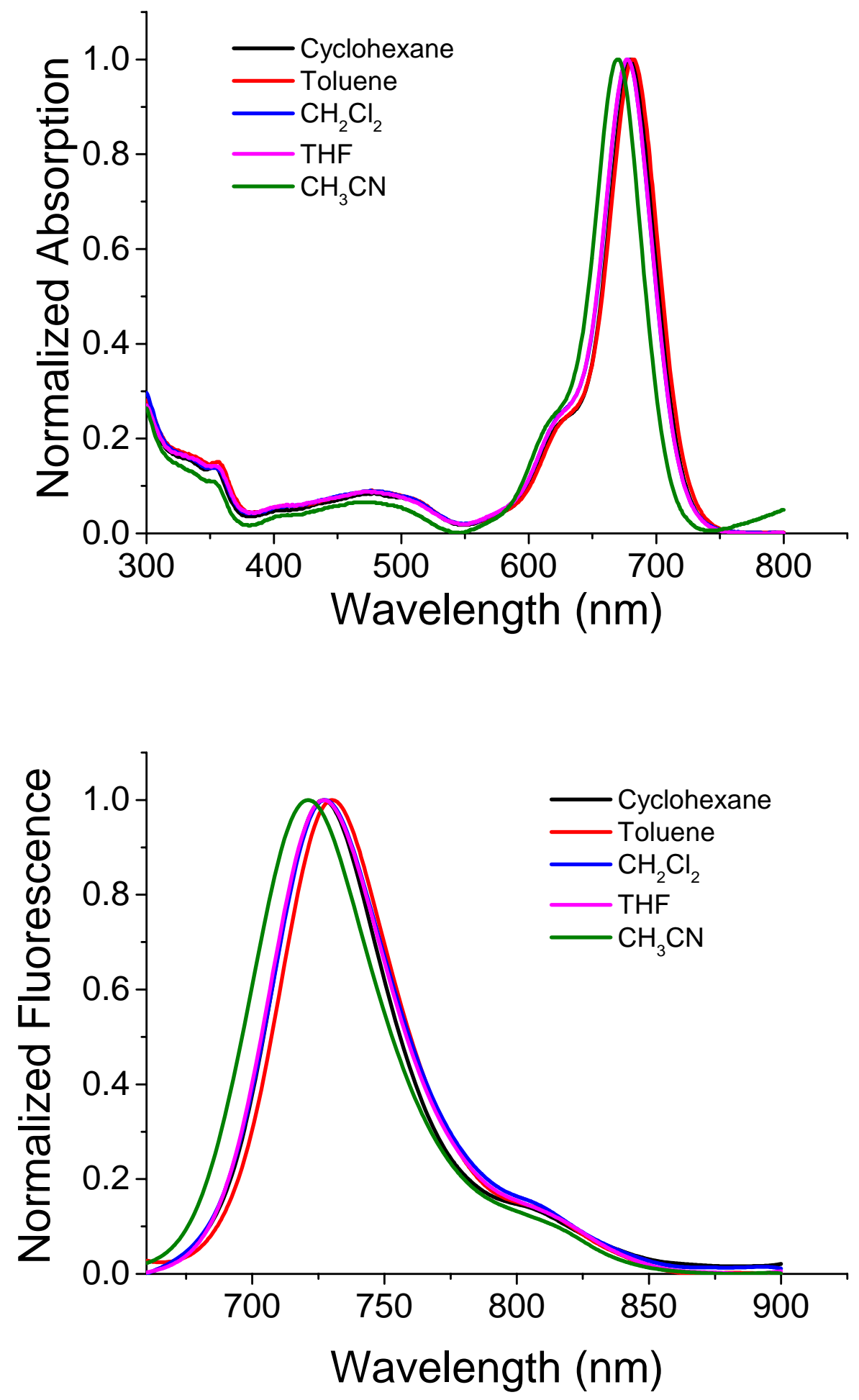

Figure S20. Normalized absorption and emission (bottom) spectra of 5c recorded in different solvents. Excited at $650 \mathrm{~nm}$. 

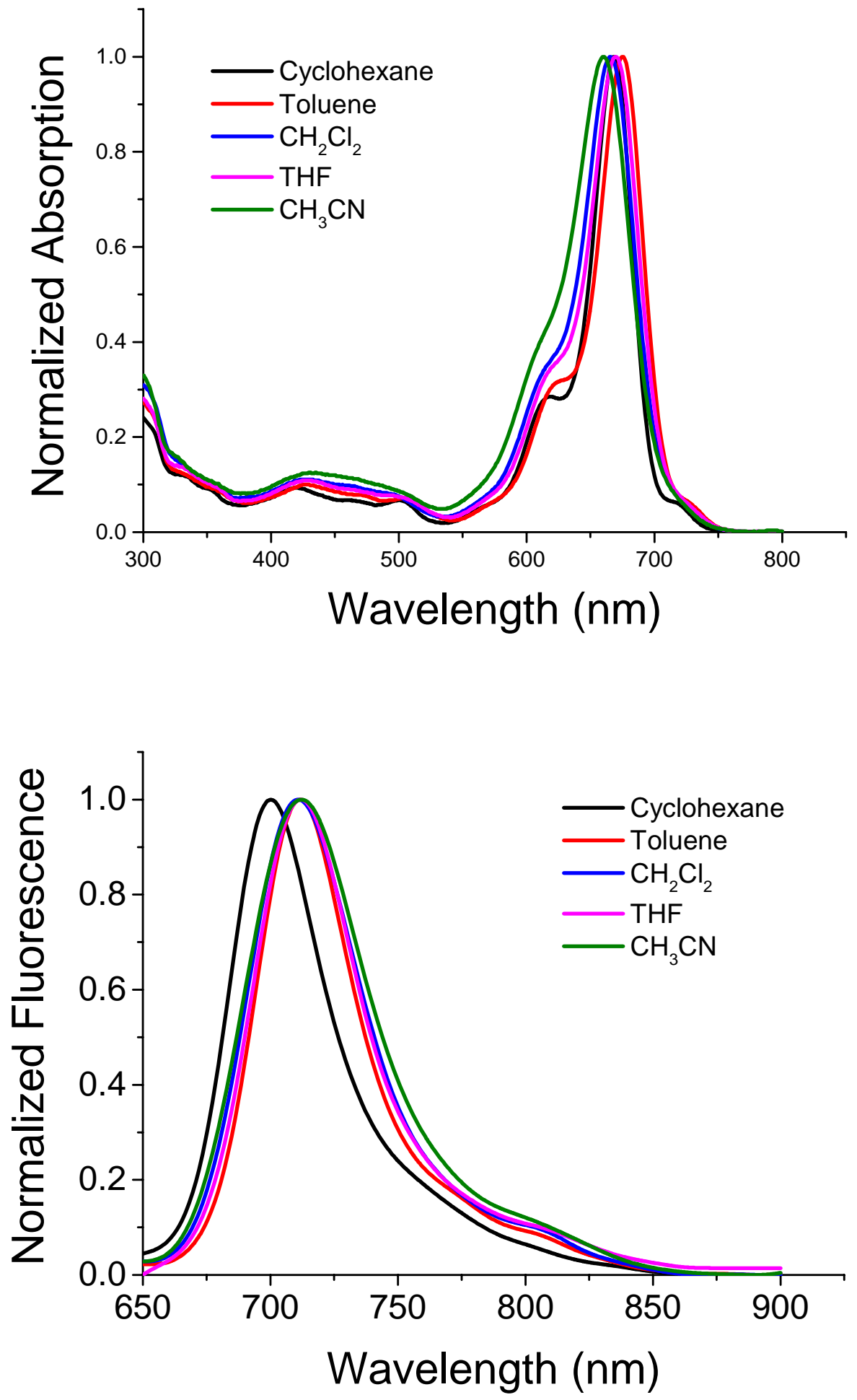

Figure S21. Normalized absorption (top) and emission (bottom) spectra of 6 recorded in different solvents. Excited at $640 \mathrm{~nm}$. 

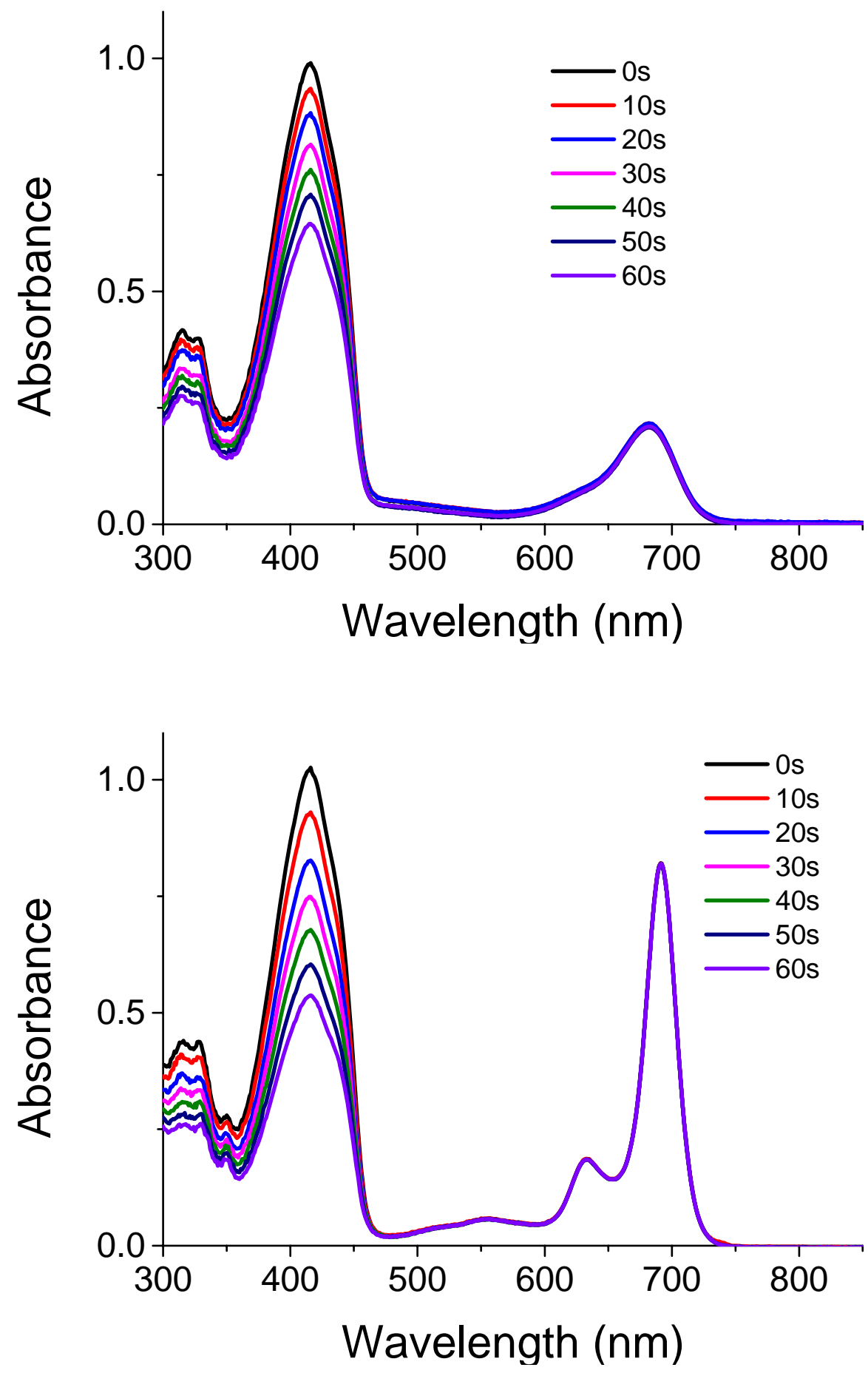

Figure S22. Absorption spectra changes of DPBF upon $660 \mathrm{~nm}$ laser irradiation in the presence of $\mathbf{H}$ for $60 \mathrm{~s}$ (recorded at $10 \mathrm{~s}$ interval) in toluene (top). Absorption spectra changes of DPBF upon irradiation in the presence of 5a-Br for $60 \mathrm{~s}$ (recorded at $10 \mathrm{~s}$ interval) in toluene (bottom). 


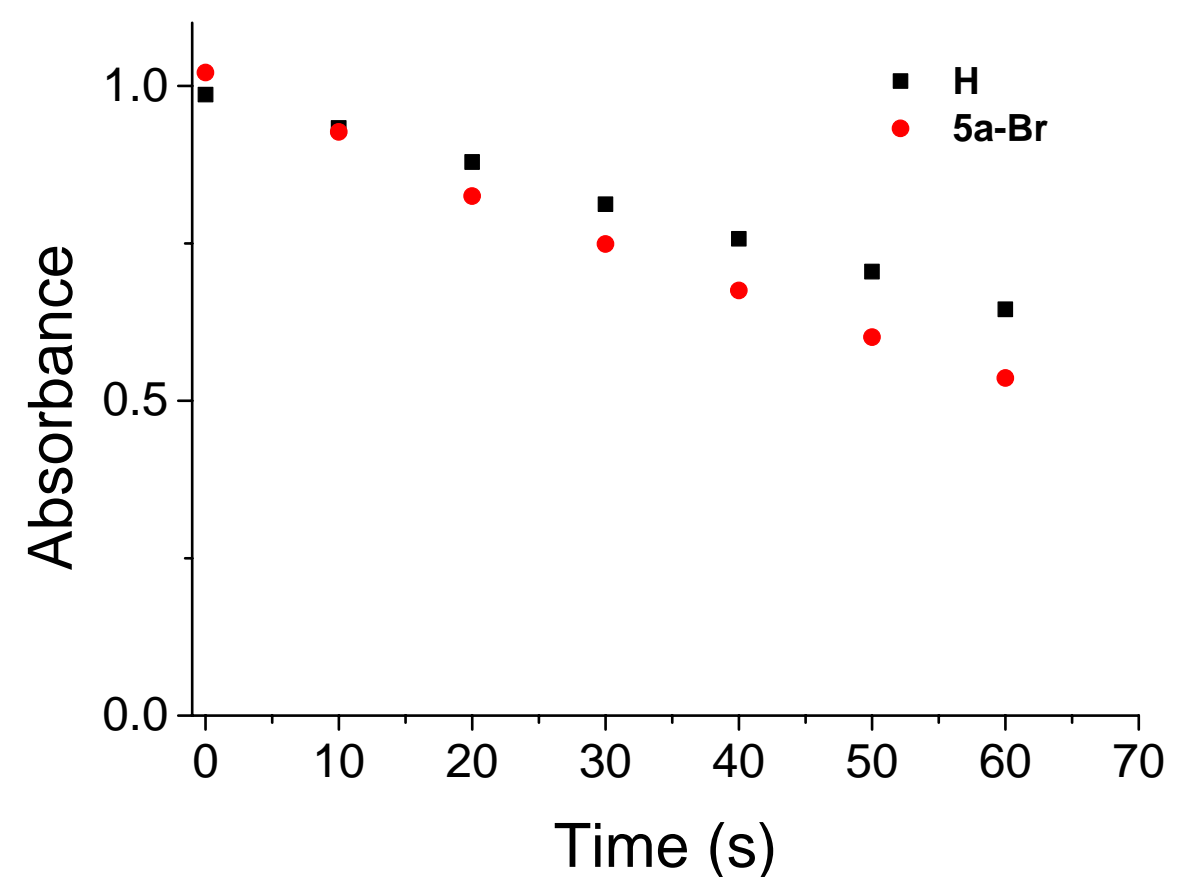

Figure S23. Comparative DPBF degradation profiles (absorbance changes at $415 \mathrm{~nm}$ ) for $60 \mathrm{~s}$ (recorded at $10 \mathrm{~s}$ interval) in toluene by $\mathbf{5 a - B r}$. 2,6-Dibromo-1,7-diphenyl-3,5-di(4-methoxylphenyl)-azaBODIPY $\left(\mathbf{H}, \Phi_{\Delta}=0.77\right.$ in toluene) 
4. Copies of ${ }^{1} \mathrm{H}$ and ${ }^{13} \mathrm{C}\left\{{ }^{1} \mathrm{H}\right\}$ NMR spectra

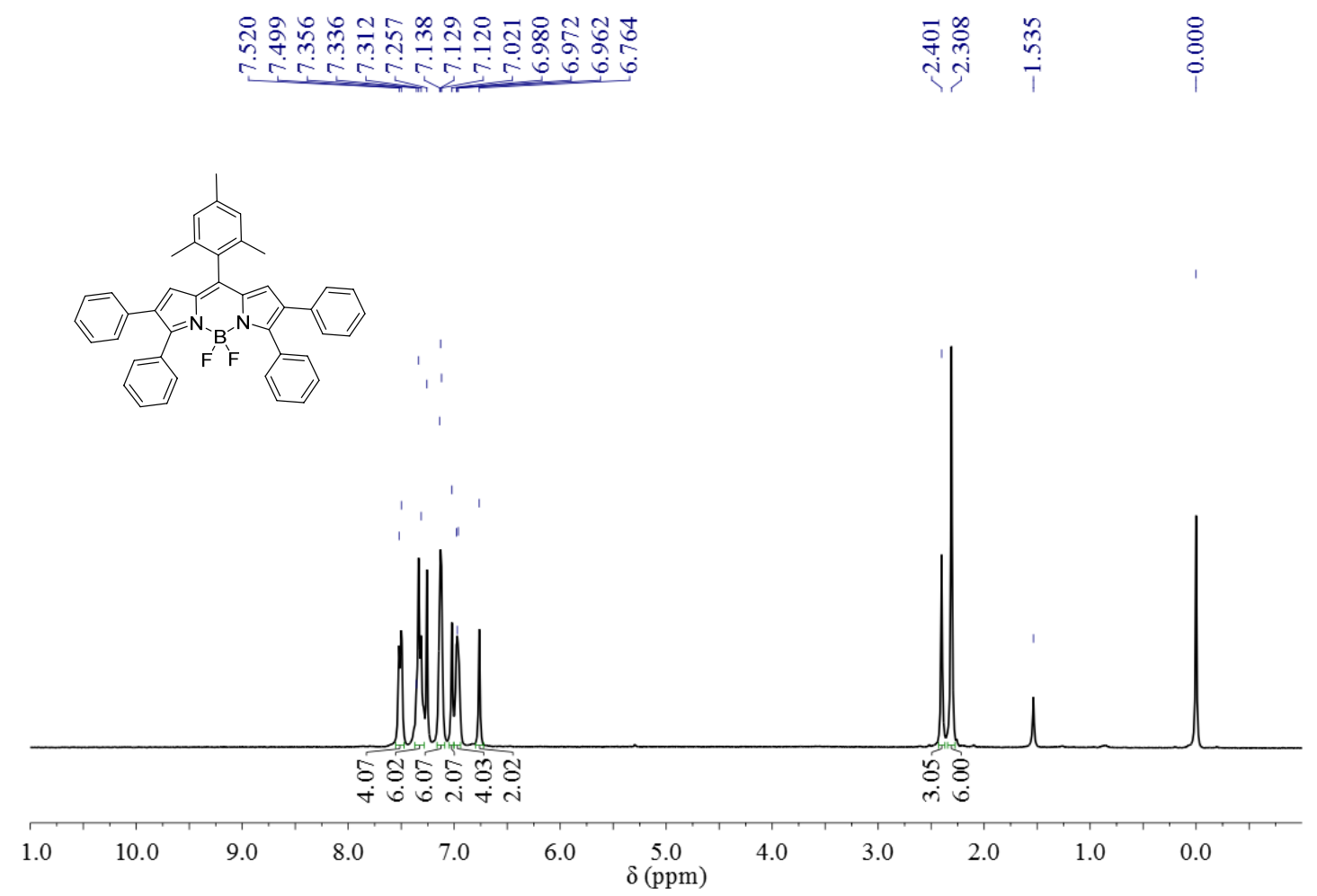

${ }^{1} \mathrm{H}$ NMR of compound 2a in $\mathrm{CDCl}_{3}$

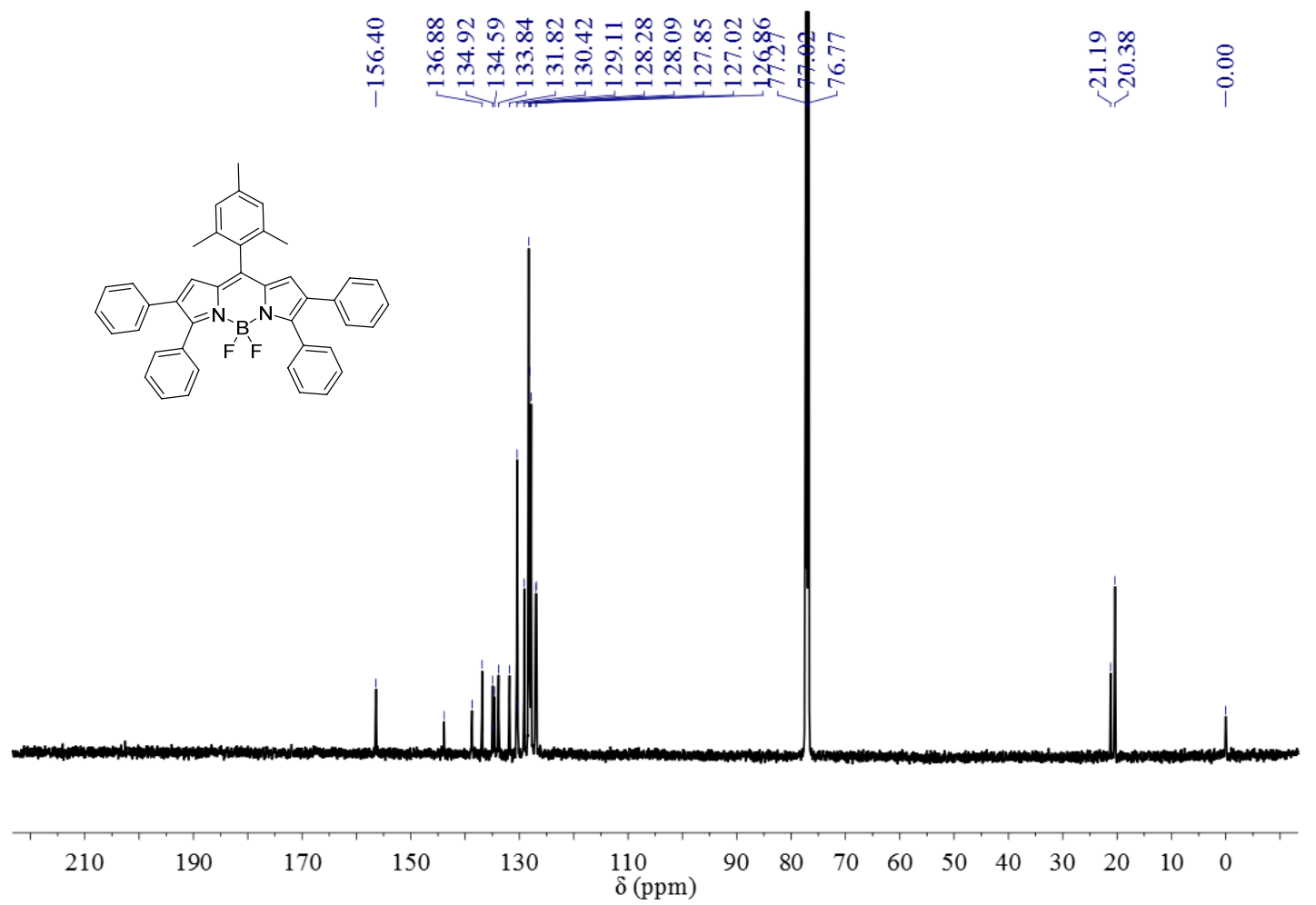


${ }^{13} \mathrm{C}\left\{{ }^{1} \mathrm{H}\right\}$ NMR of compound 2a in $\mathrm{CDCl}_{3}$

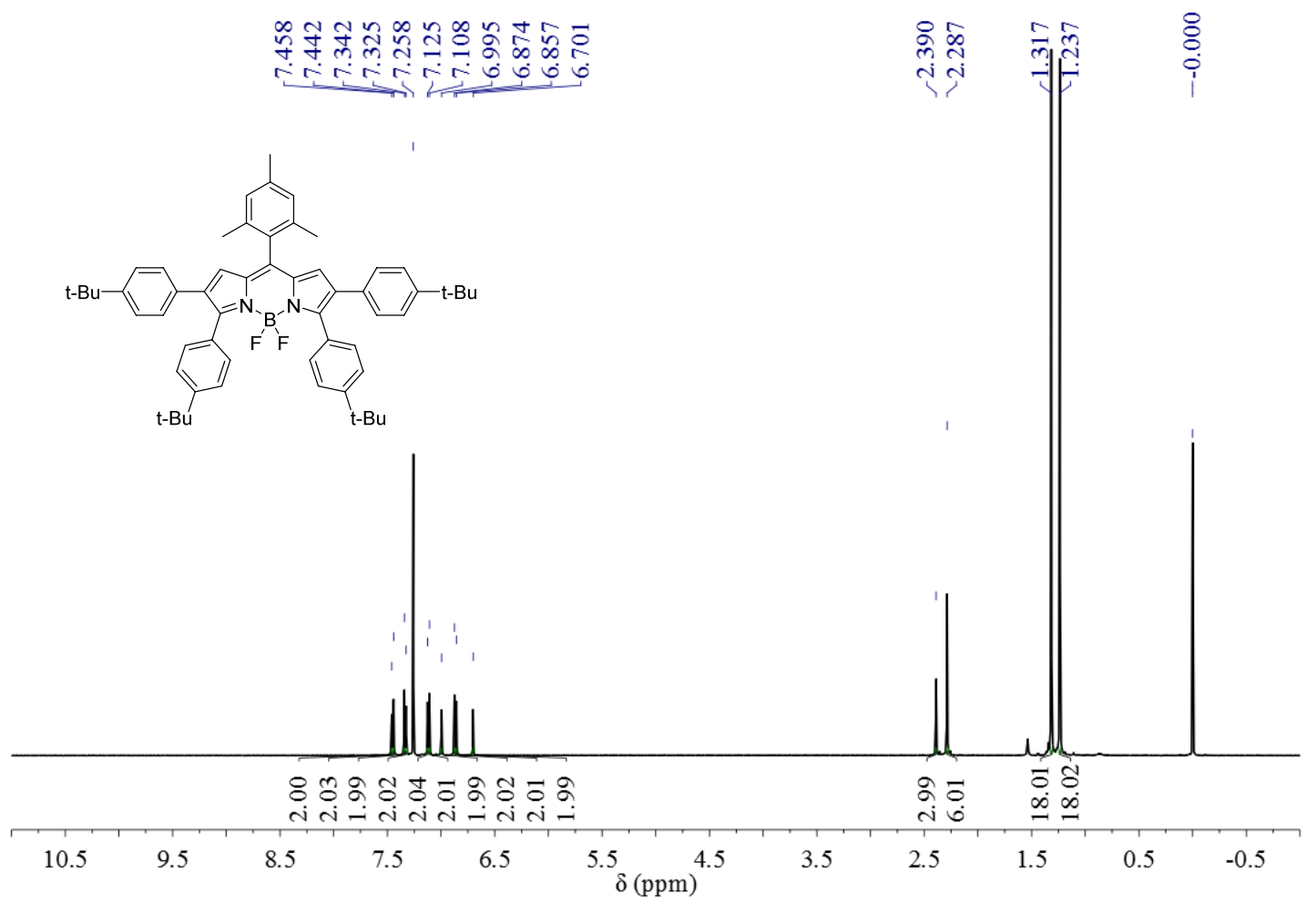

${ }^{1} \mathrm{H}$ NMR of compound $\mathbf{2 b}$ in $\mathrm{CDCl}_{3}$

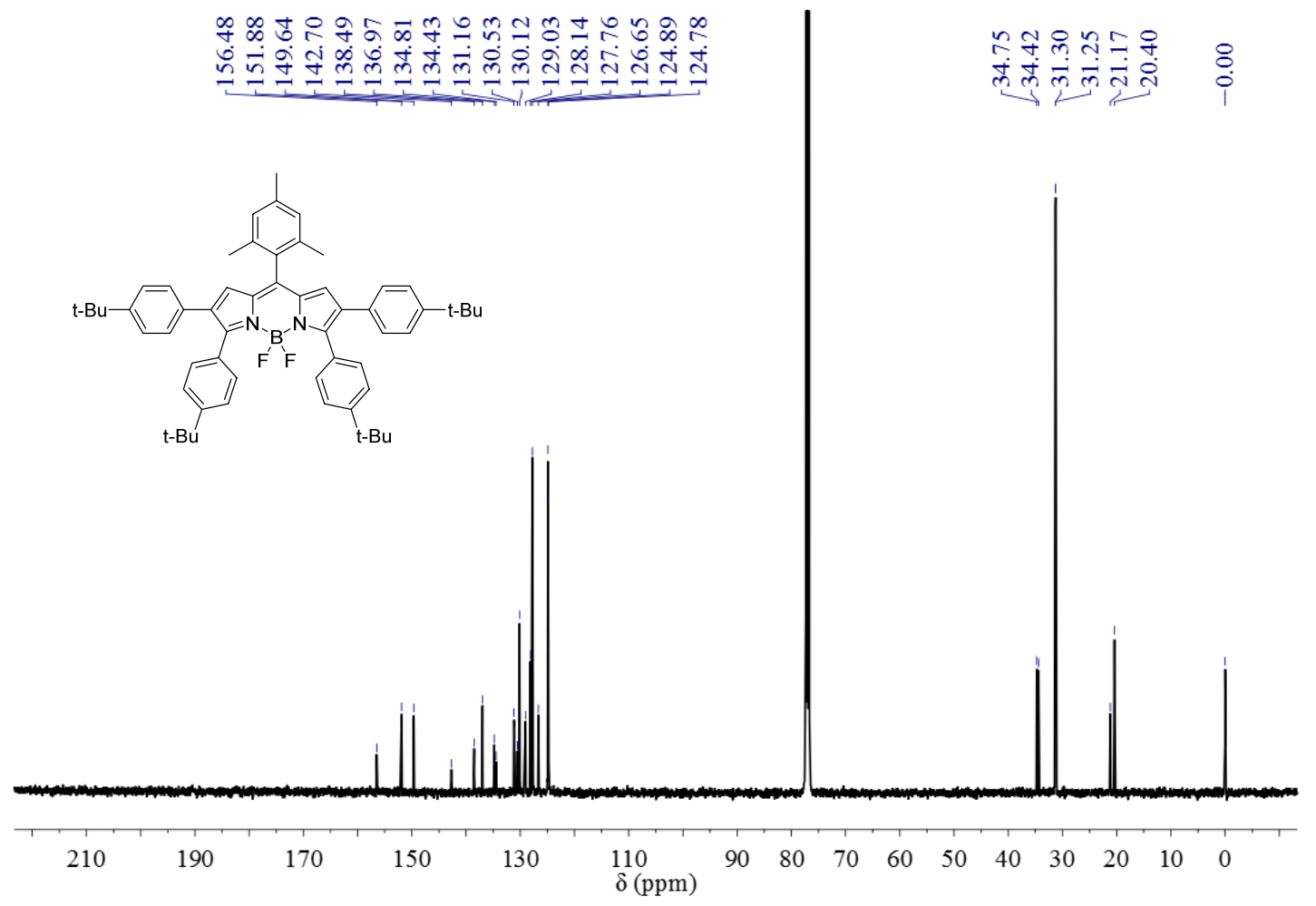

${ }^{13} \mathrm{C}\left\{{ }^{1} \mathrm{H}\right\}$ NMR of compound $\mathbf{2 b}$ in $\mathrm{CDCl}_{3}$ 


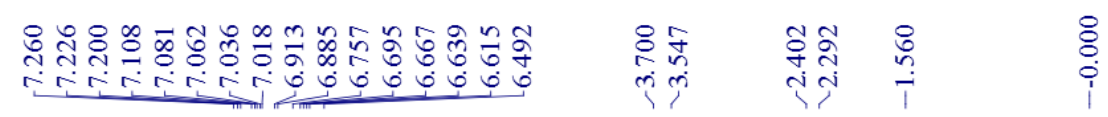
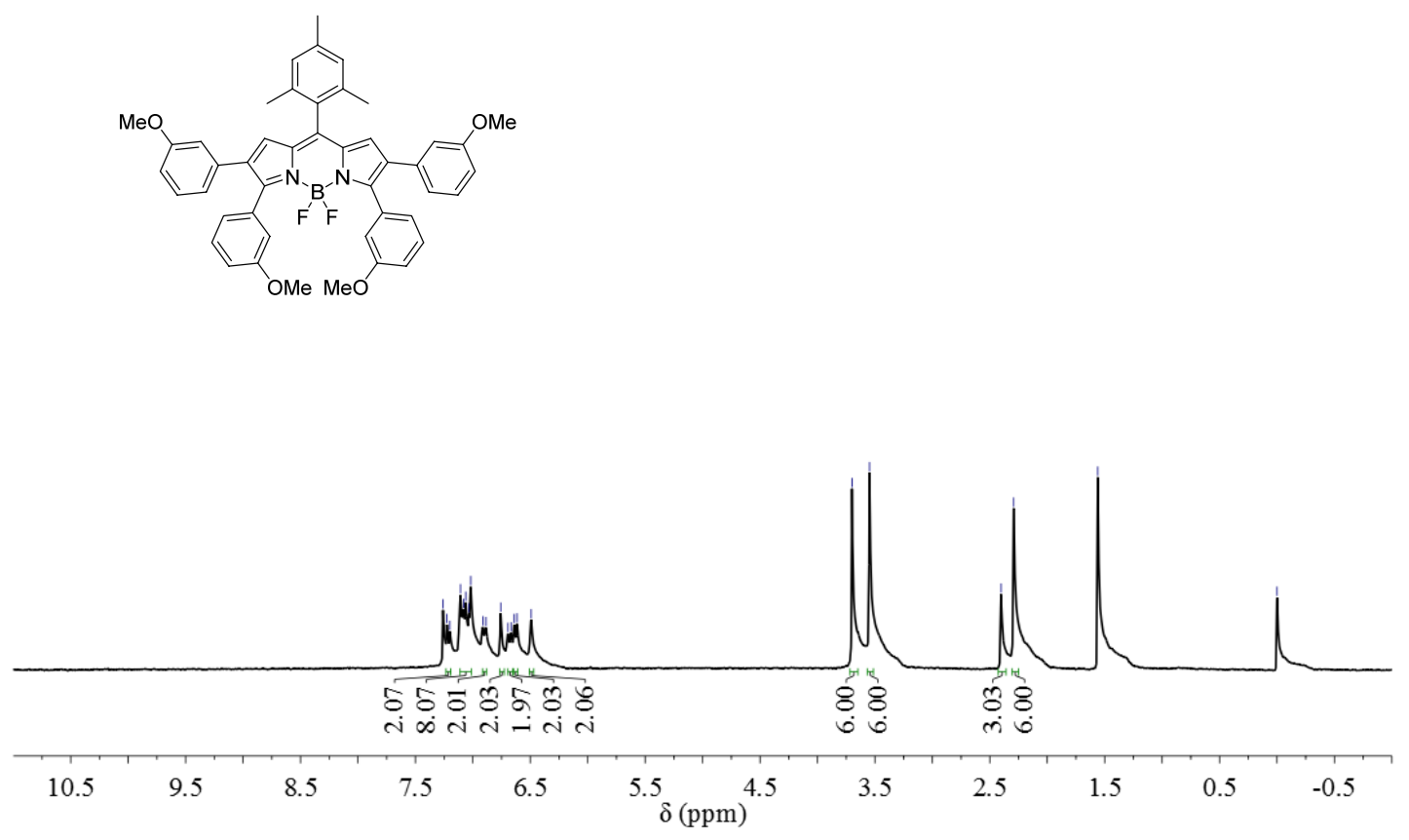

${ }^{1} \mathrm{H}$ NMR of compound 2c in $\mathrm{CDCl}_{3}$
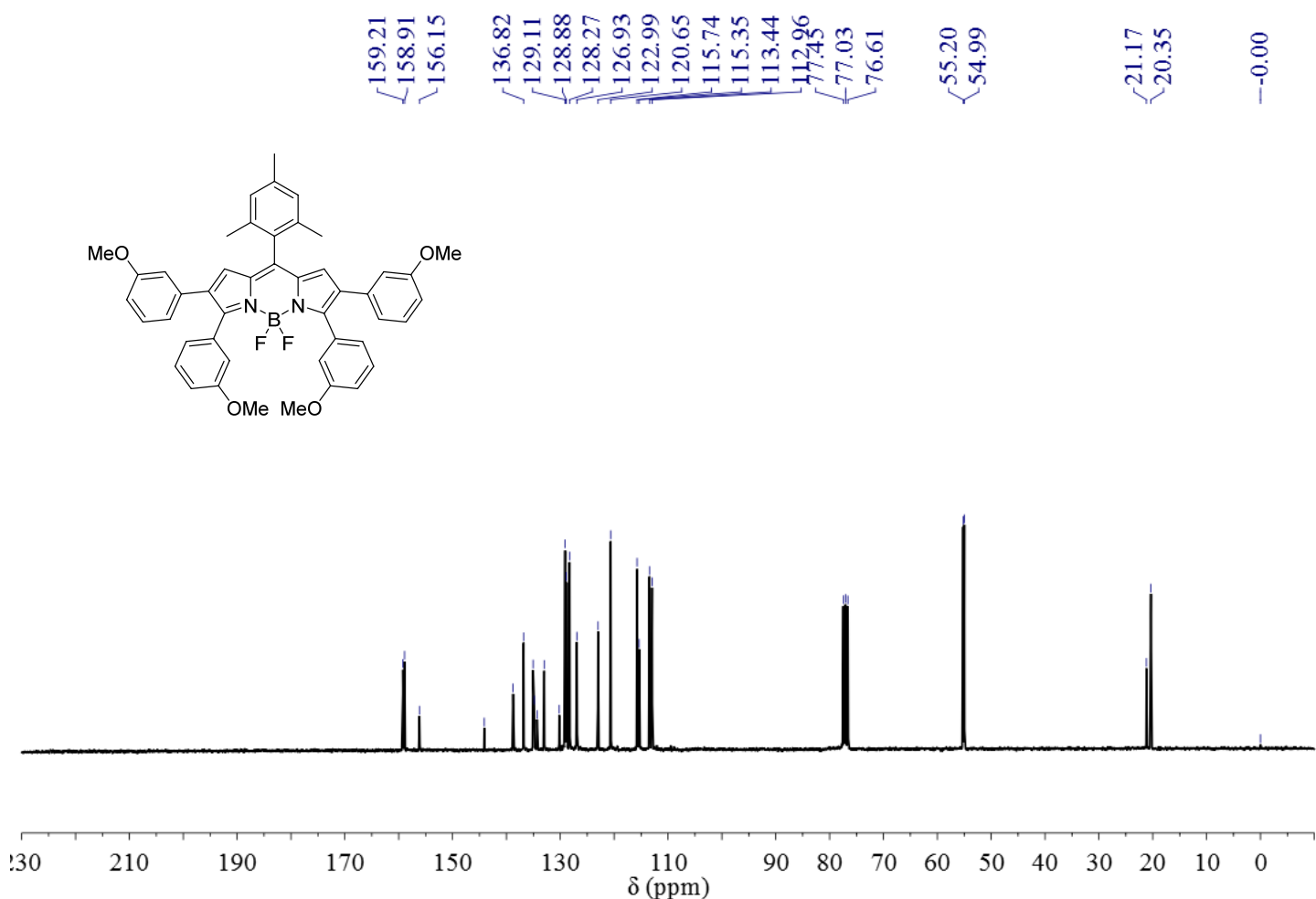

${ }^{13} \mathrm{C}\left\{{ }^{1} \mathrm{H}\right\}$ NMR of compound 2c in $\mathrm{CDCl}_{3}$ 


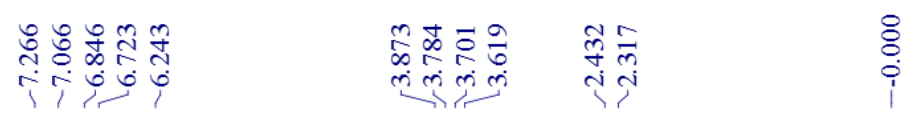
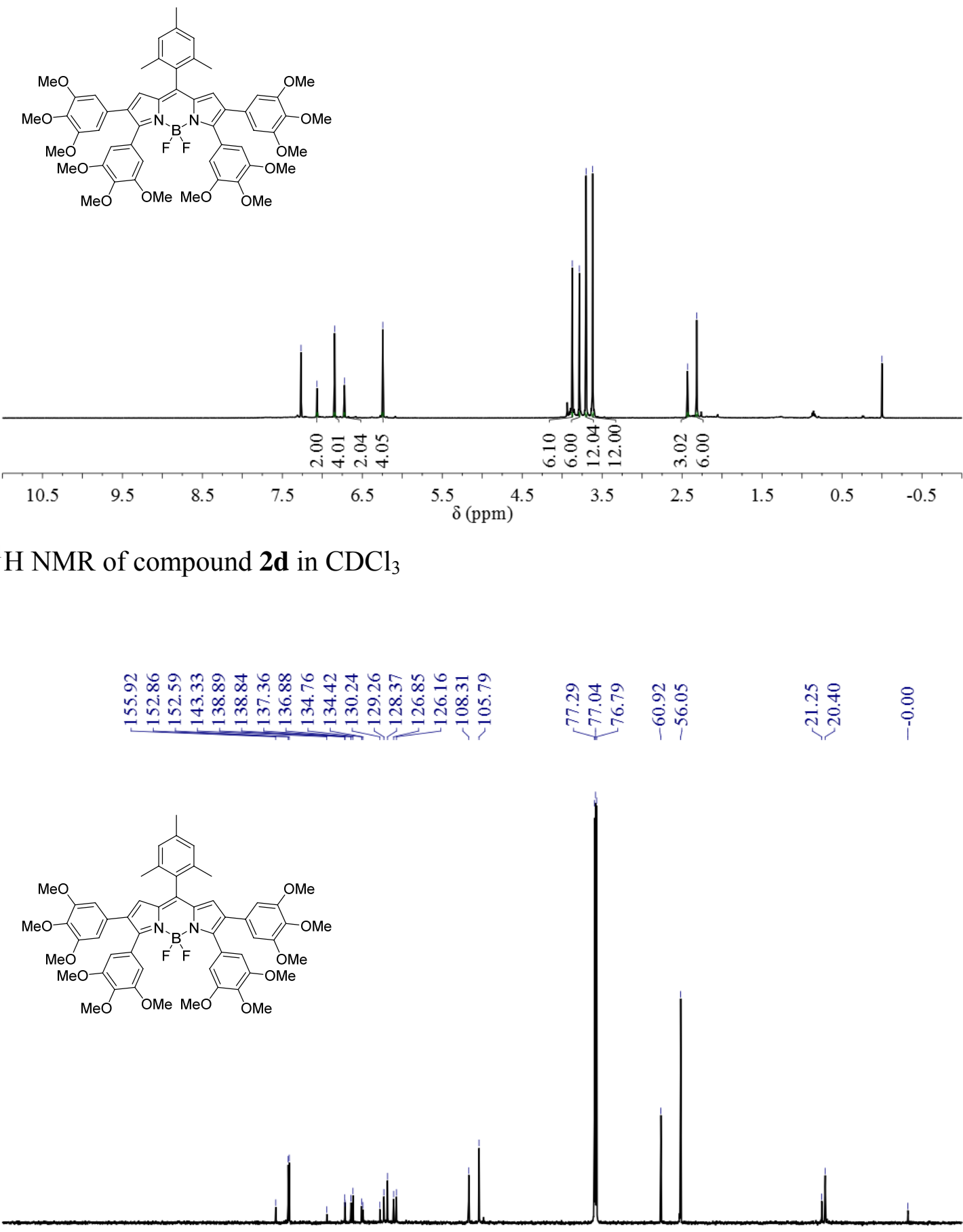

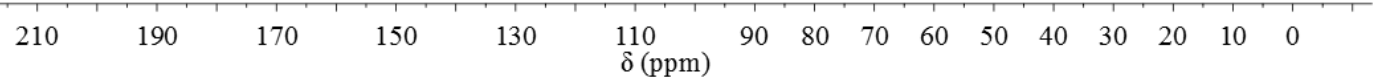

${ }^{13} \mathrm{C}\left\{{ }^{1} \mathrm{H}\right\}$ NMR of compound $\mathbf{2 d}$ in $\mathrm{CDCl}_{3}$ 


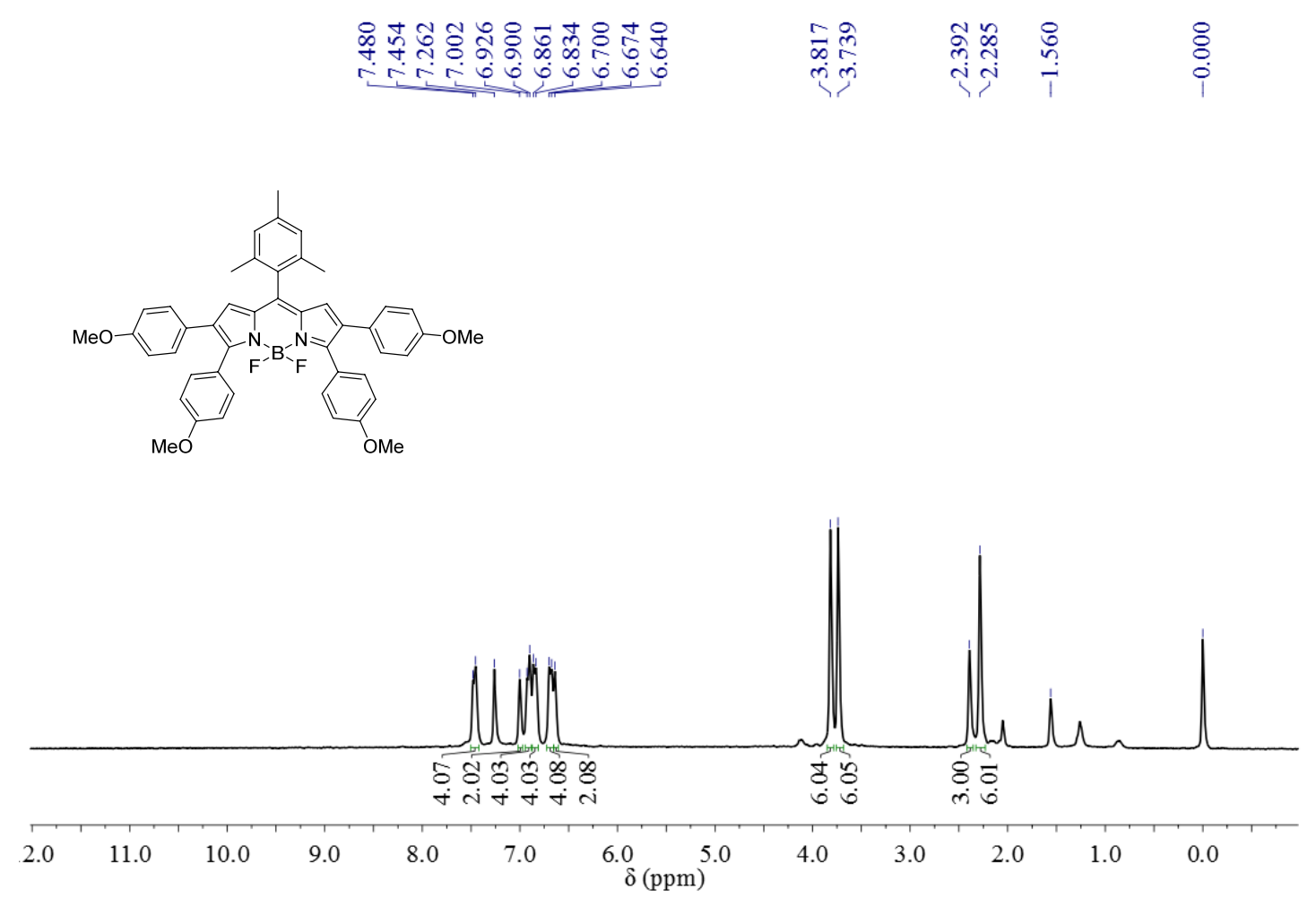

${ }^{1} \mathrm{H}$ NMR of compound $2 \mathbf{e}$ in $\mathrm{CDCl}_{3}$
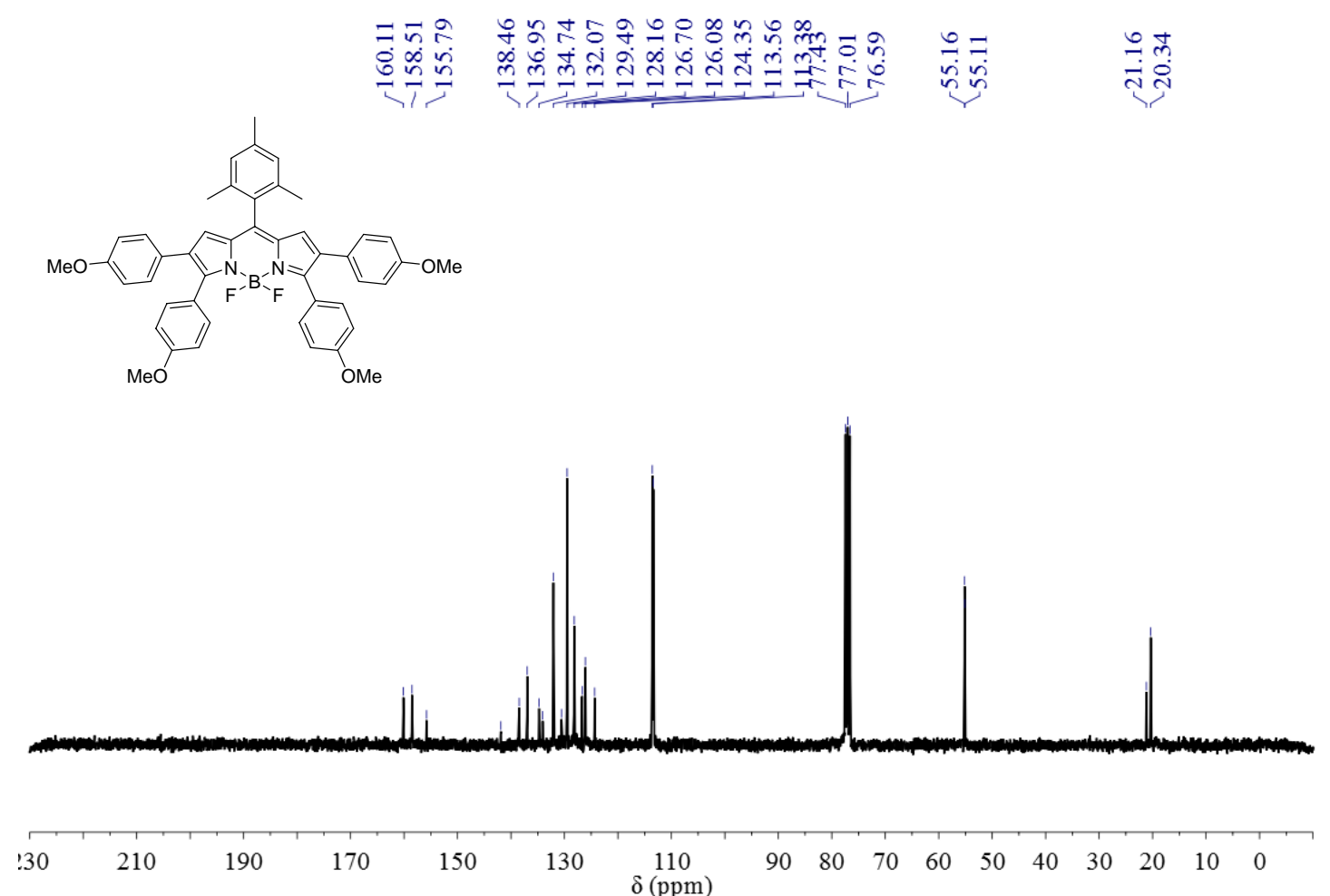

${ }^{13} \mathrm{C}\left\{{ }^{1} \mathrm{H}\right\}$ NMR of compound $2 \mathbf{e}$ in $\mathrm{CDCl}_{3}$ 

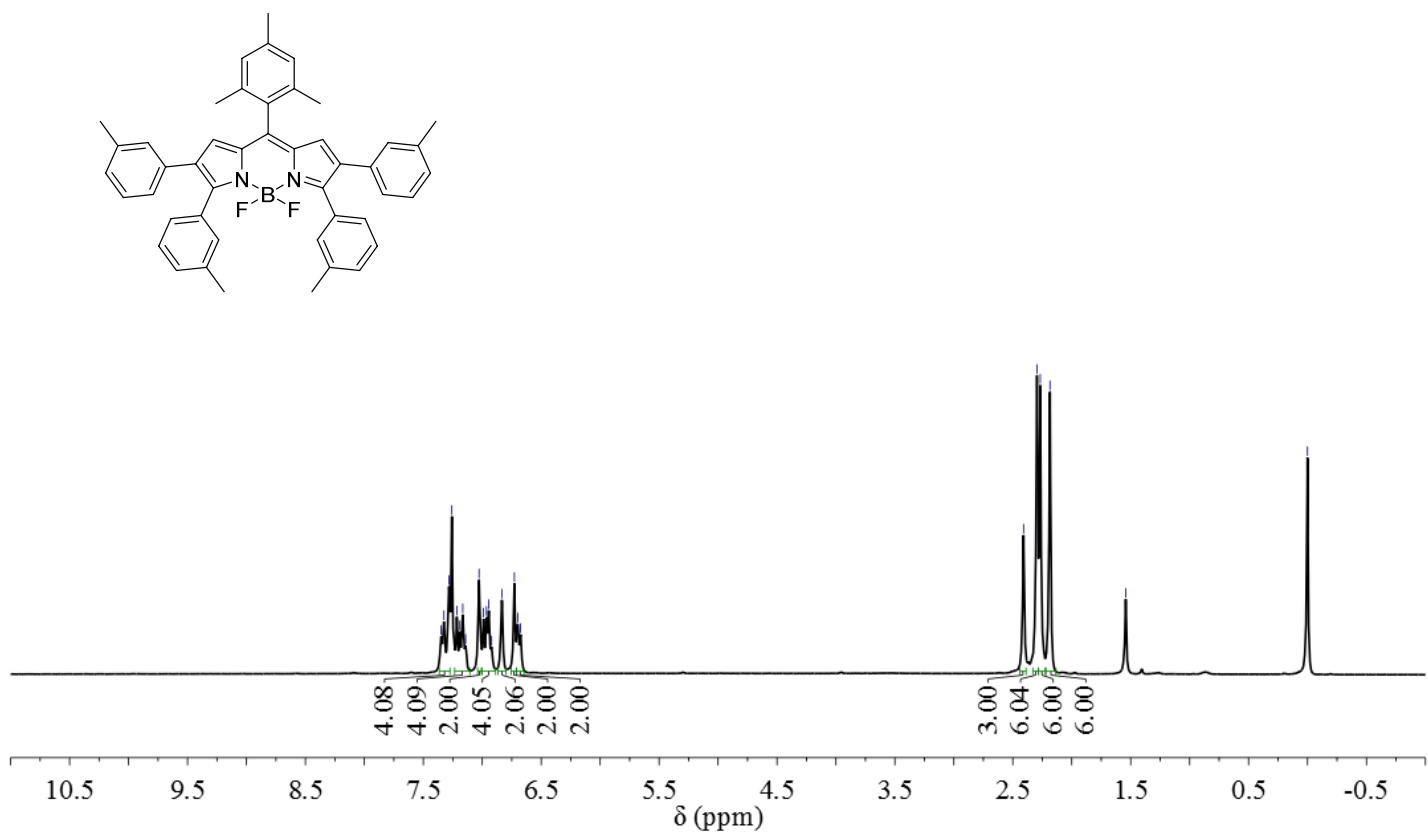

${ }^{1} \mathrm{H}$ NMR of compound $2 \mathbf{f}$ in $\mathrm{CDCl}_{3}$

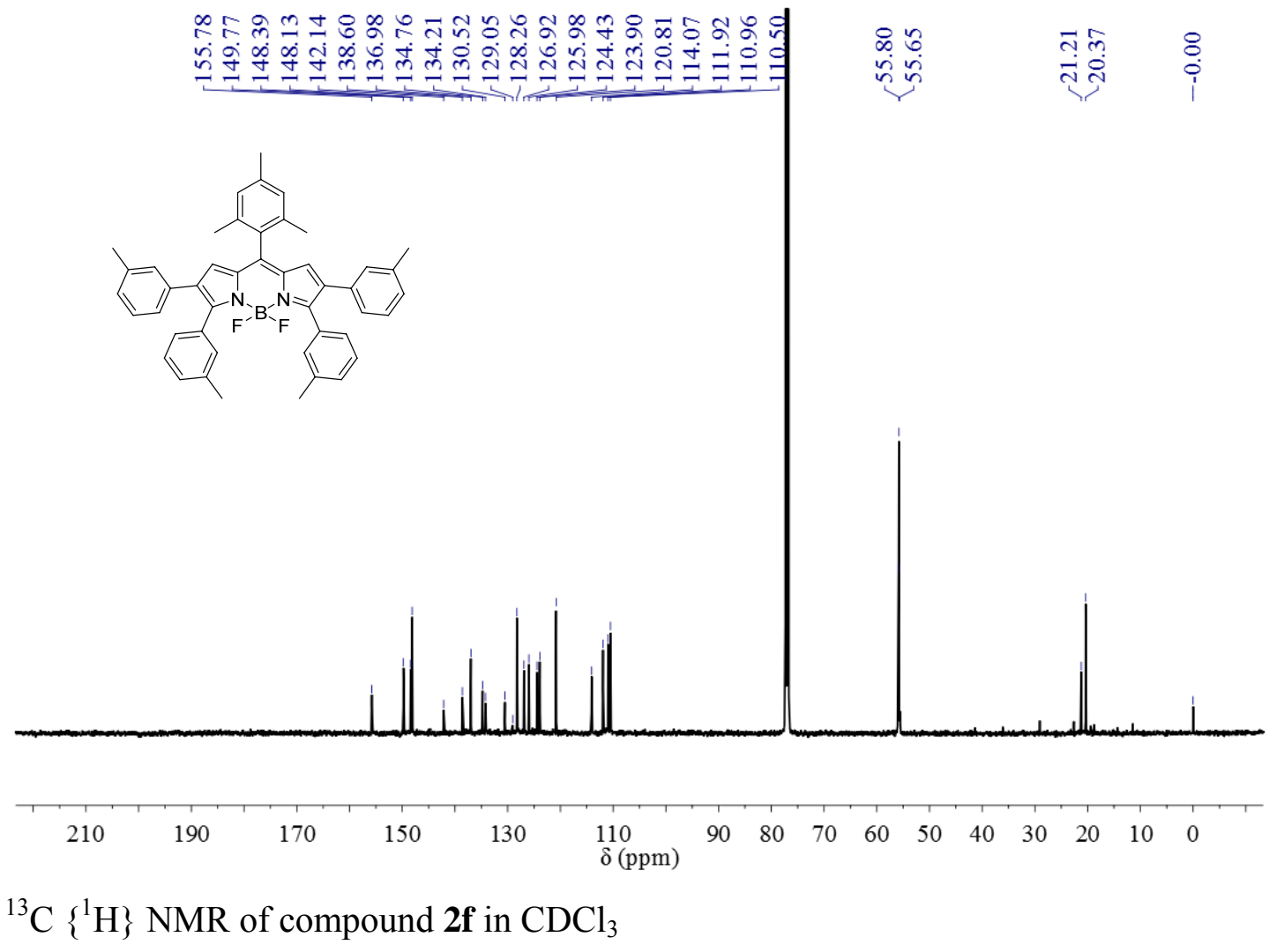



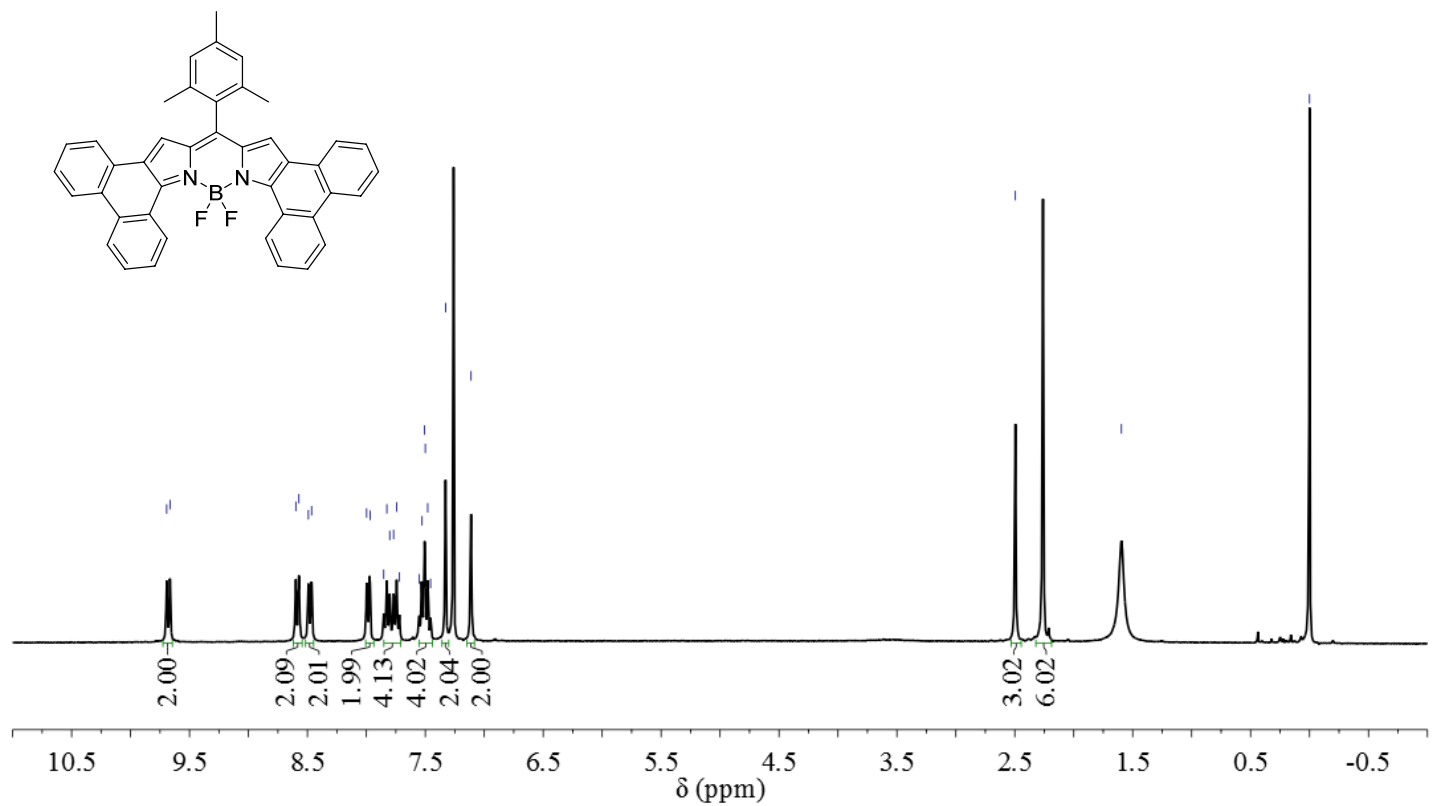

${ }^{1} \mathrm{H}$ NMR of compound $3 \mathbf{a}$ in $\mathrm{CDCl}_{3}$

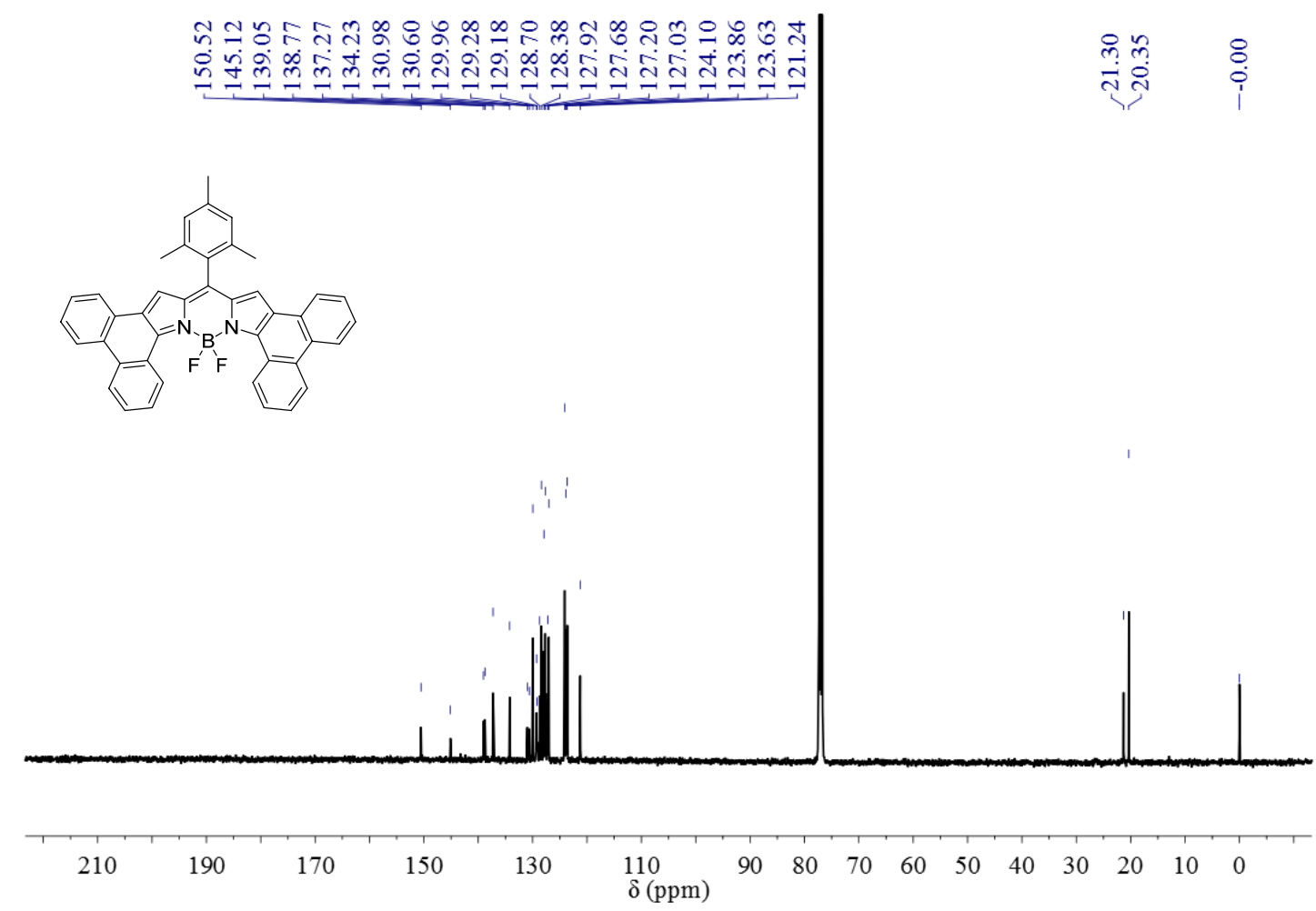

${ }^{13} \mathrm{C}\left\{{ }^{1} \mathrm{H}\right\}$ NMR of compound 3a in $\mathrm{CDCl}_{3}$ 

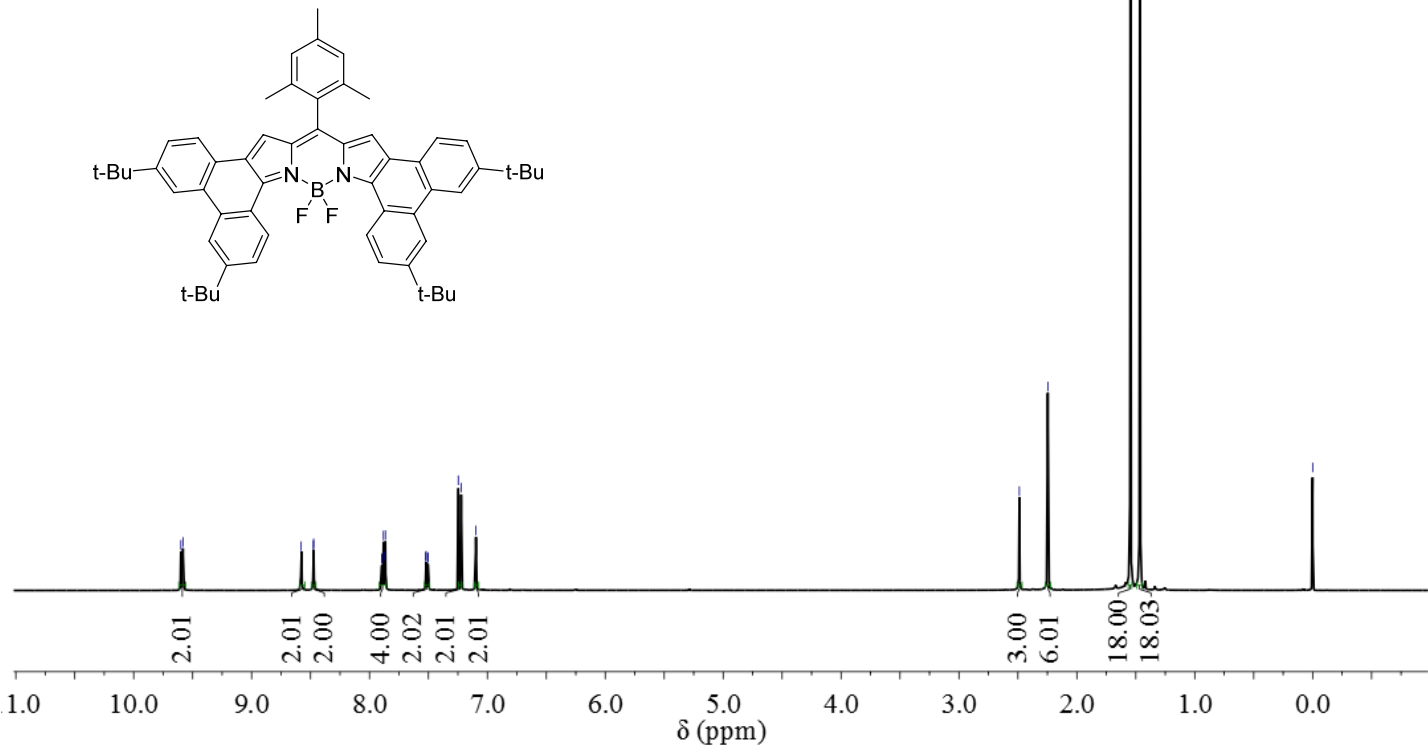

${ }^{1} \mathrm{H}$ NMR of compound $\mathbf{3 b}$ in $\mathrm{CDCl}_{3}$

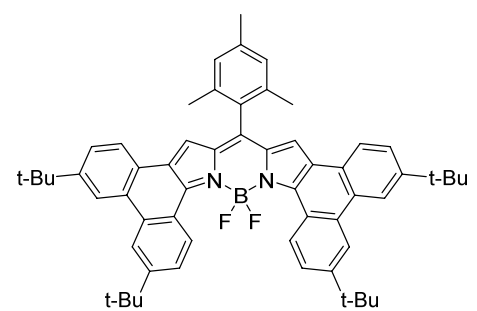

$\begin{array}{llllll}210 & 190 & 170 & 150 & 130 & 110 \\ \delta(\mathrm{ppm})\end{array}$

$\begin{array}{llllllllll}90 & 80 & 70 & 60 & 50 & 40 & 30 & 20 & 10 & 0\end{array}$

${ }^{13} \mathrm{C}\left\{{ }^{1} \mathrm{H}\right\}$ NMR of compound $\mathbf{3 b}$ in $\mathrm{CDCl}_{3}$ 


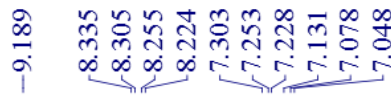

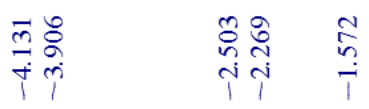
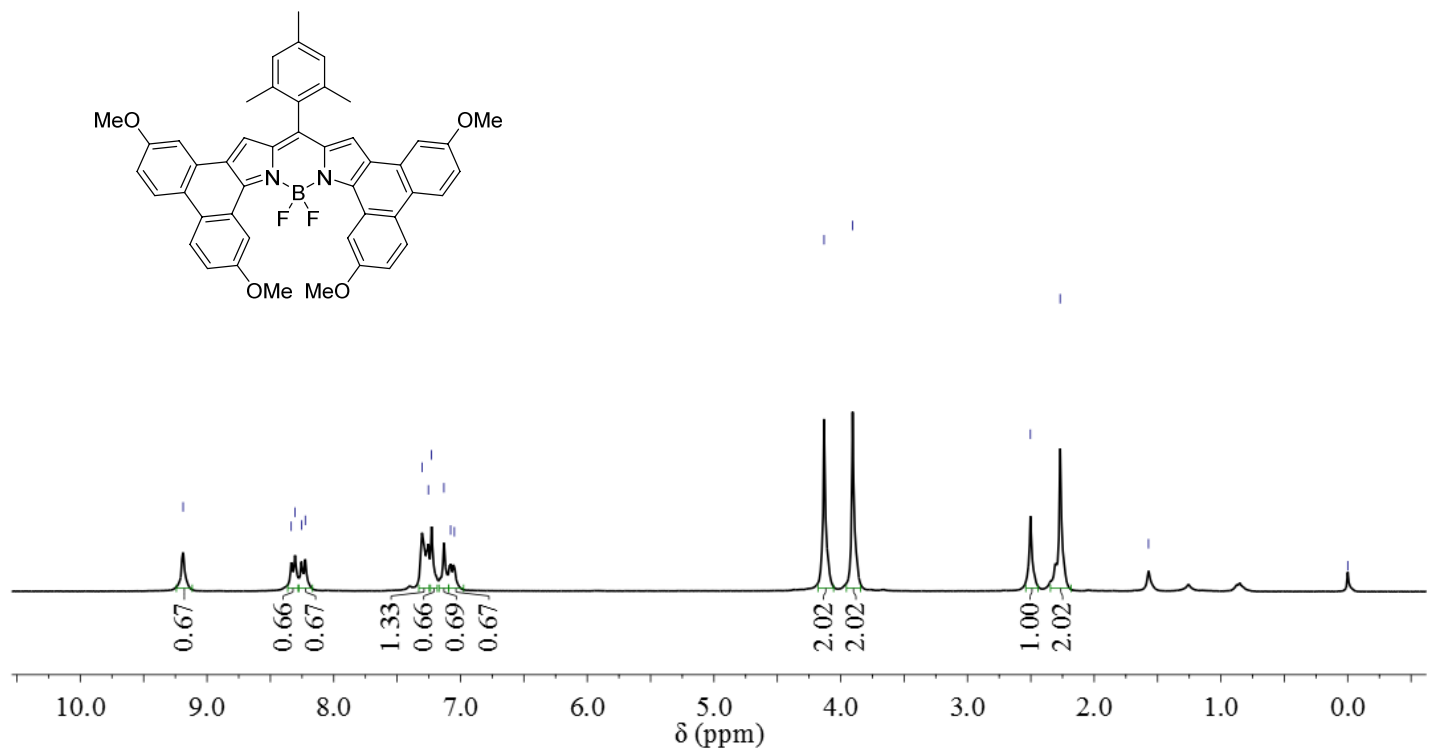

${ }^{1} \mathrm{H}$ NMR of compound $3 \mathrm{c}$ in $\mathrm{CDCl}_{3}$

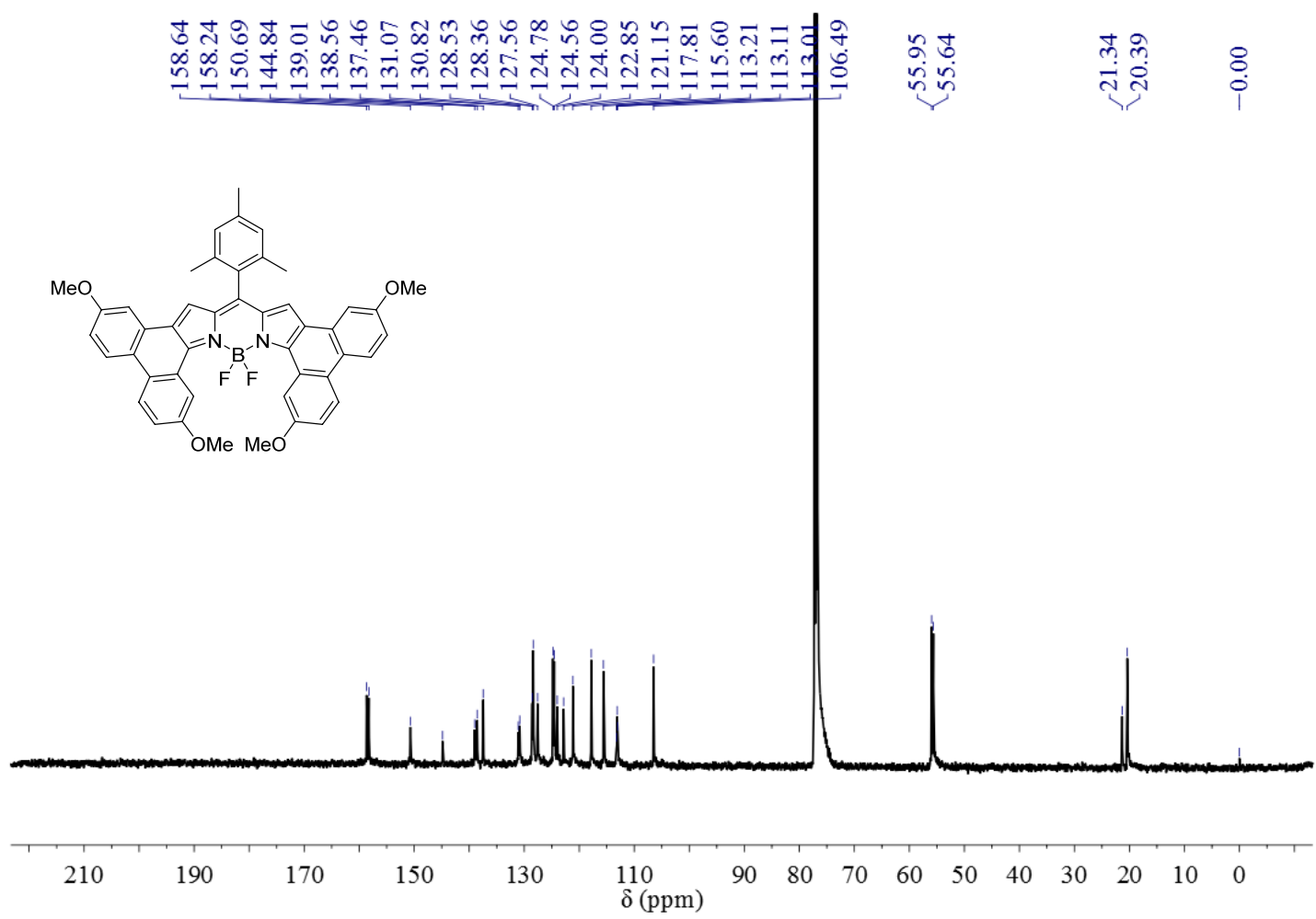

${ }^{13} \mathrm{C}\left\{{ }^{1} \mathrm{H}\right\}$ NMR of compound $3 \mathrm{c}$ in $\mathrm{CDCl}_{3}$ 


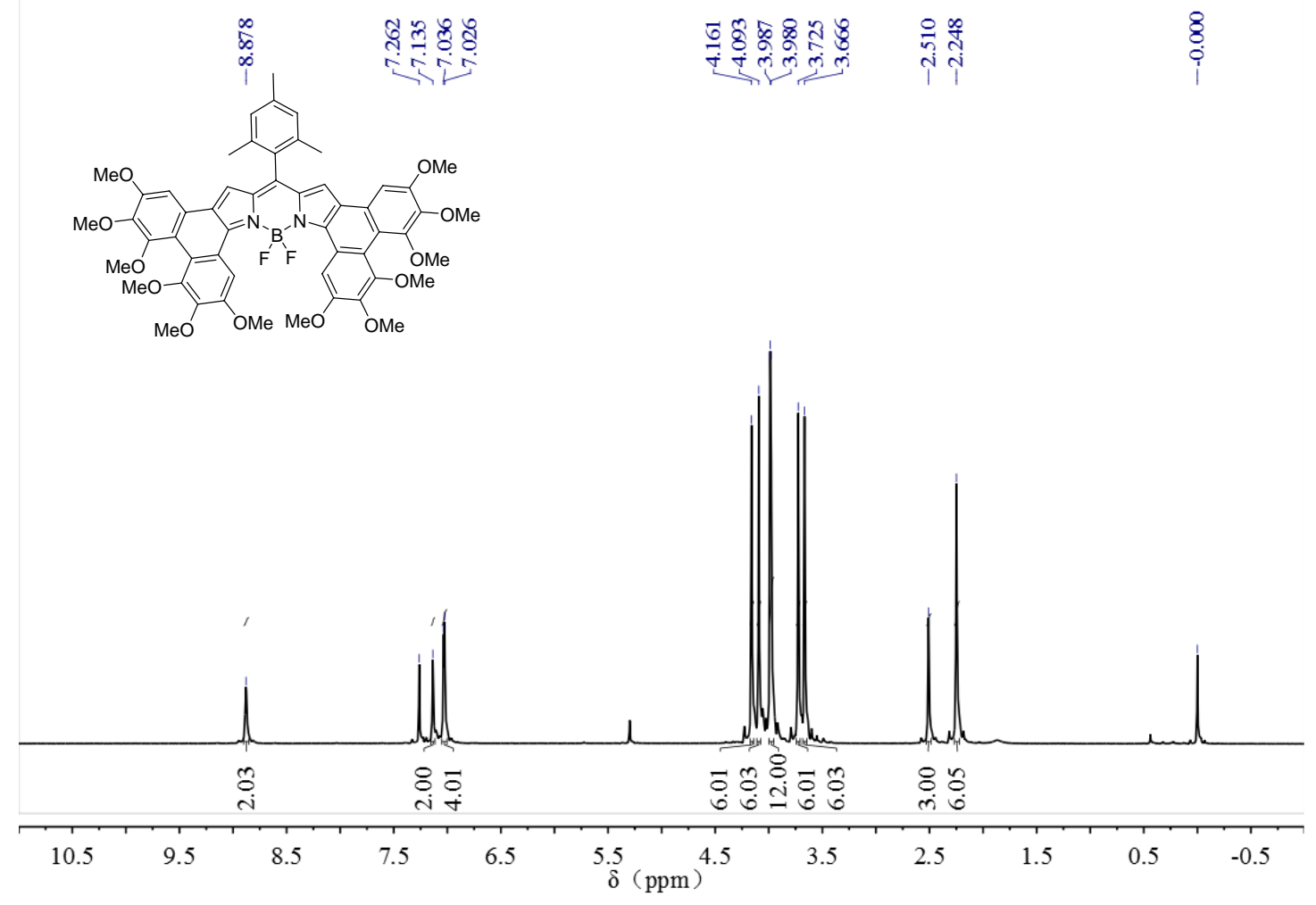

${ }^{1} \mathrm{H} \mathrm{NMR}$ of compound $\mathbf{3 d}$ in $\mathrm{CDCl}_{3}$
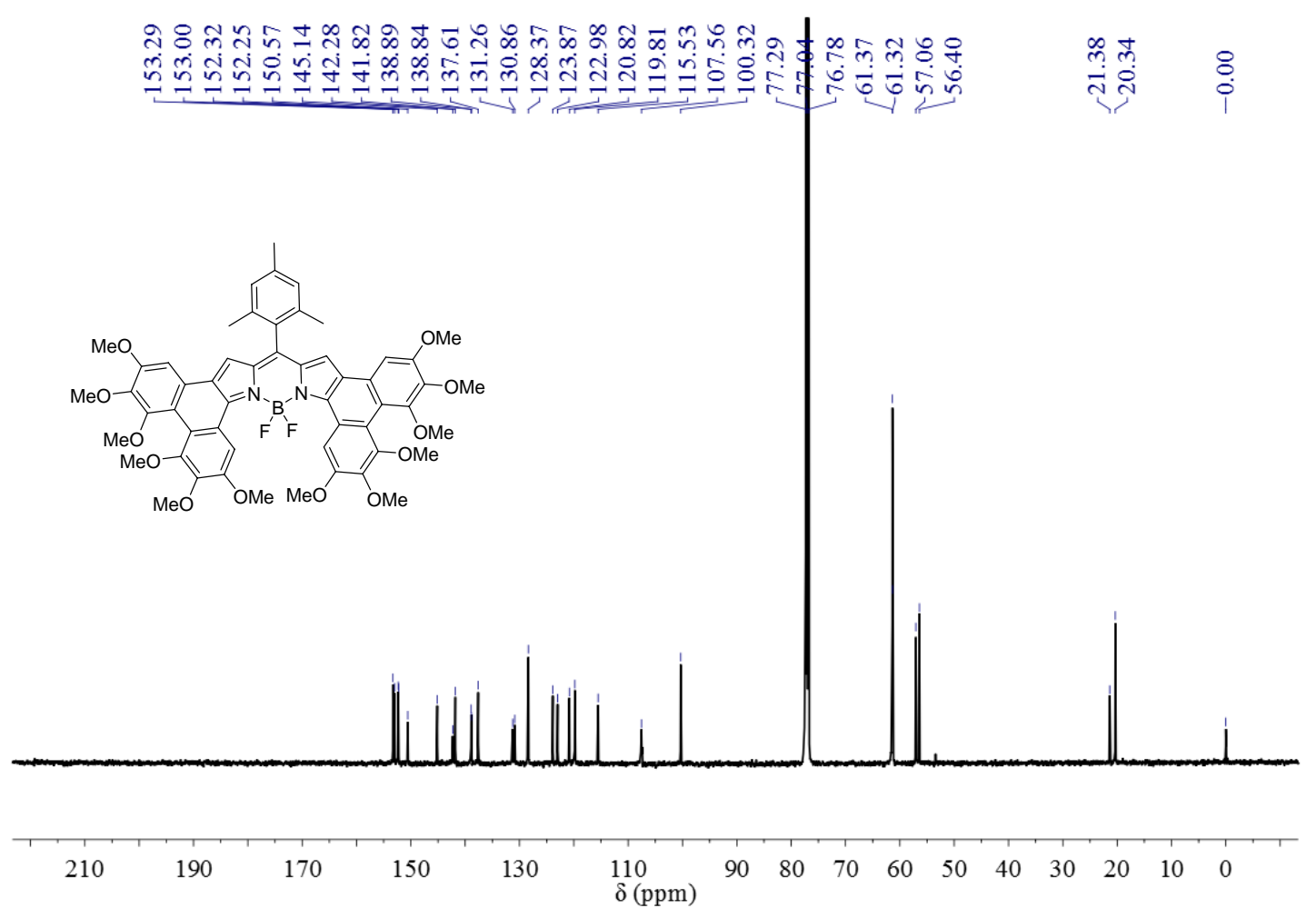

${ }^{13} \mathrm{C}\left\{{ }^{1} \mathrm{H}\right\}$ NMR of compound $3 d$ in $\mathrm{CDCl}_{3}$ 


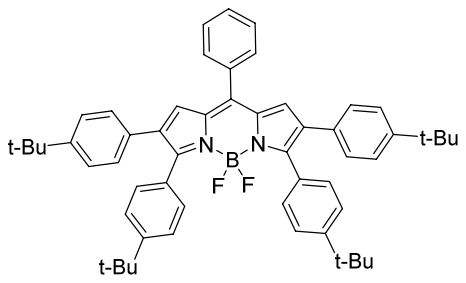

\section{Now}

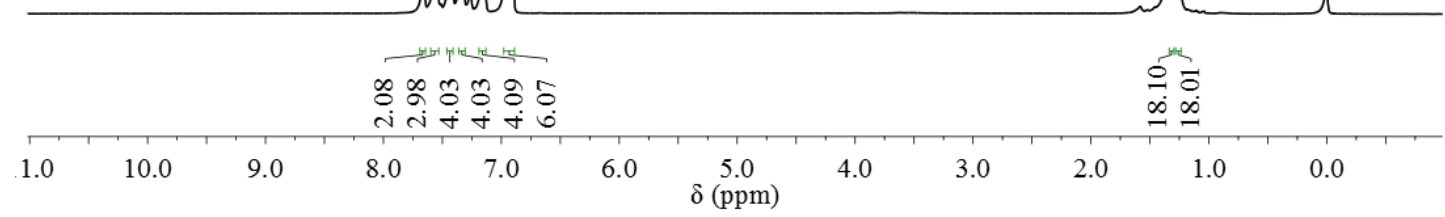

${ }^{1} \mathrm{H} \mathrm{NMR}$ of compound $\mathbf{4 a}$ in $\mathrm{CDCl}_{3}$
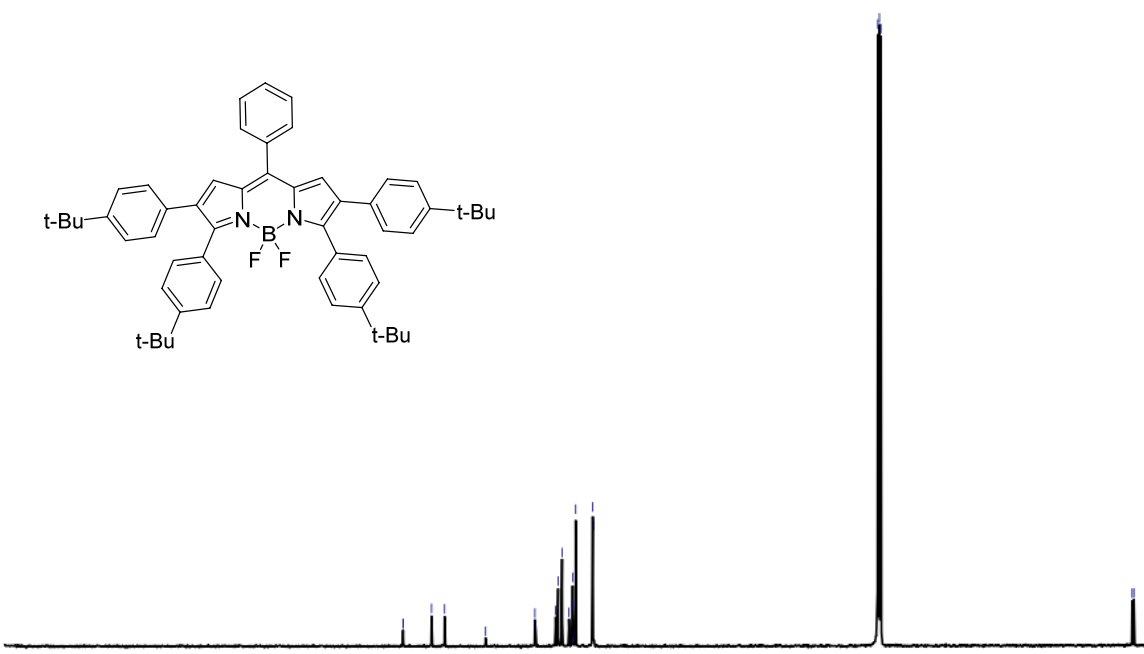

210

$190 \quad 170$

150

130

110

$\begin{array}{llllllllll}90 & 80 & 70 & 60 & 50 & 40 & 30 & 20 & 10 & 0\end{array}$

${ }^{13} \mathrm{C}\left\{{ }^{1} \mathrm{H}\right\}$ NMR of compound $\mathbf{4 a}$ in $\mathrm{CDCl}_{3}$ 


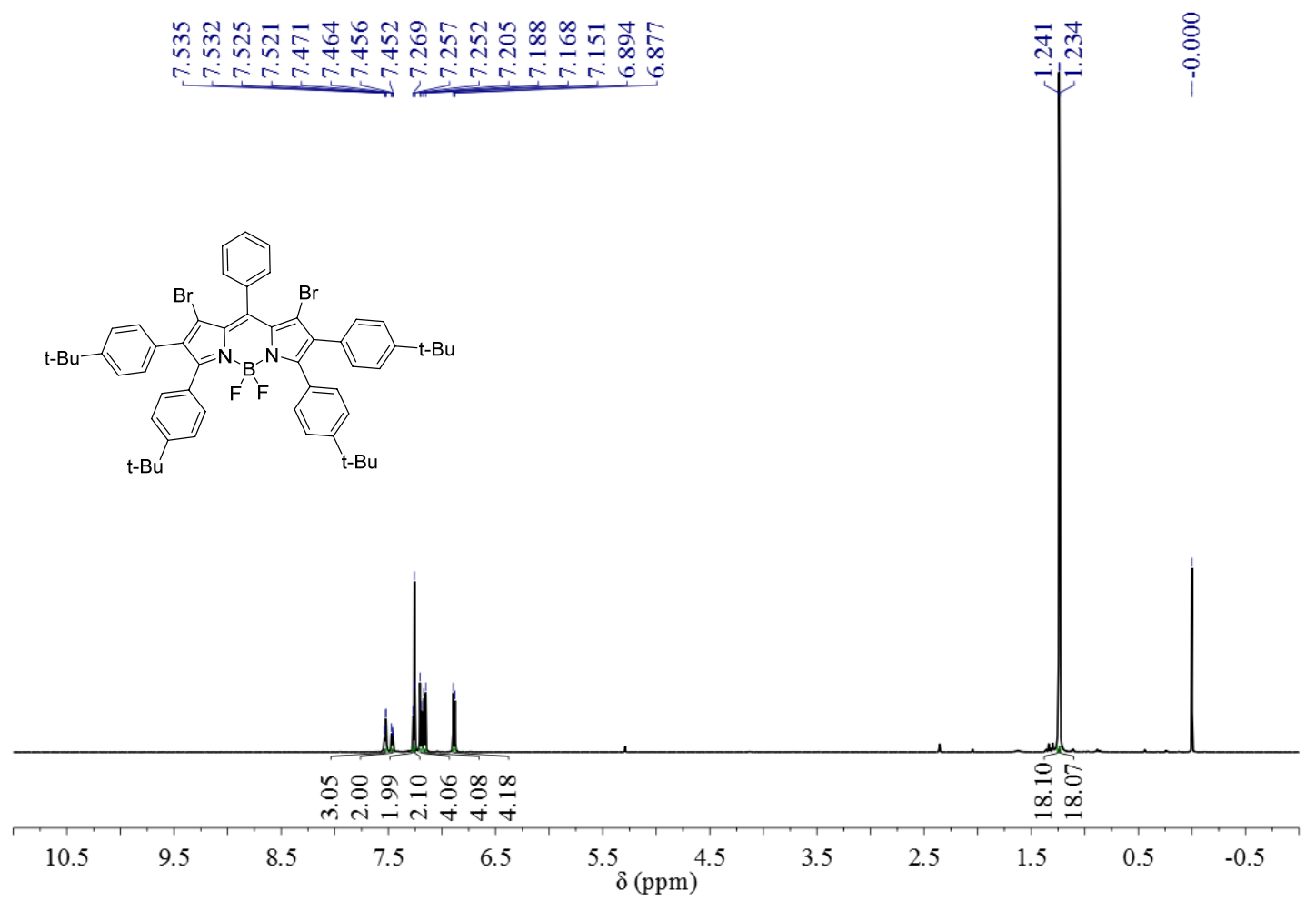

${ }^{1} \mathrm{H}$ NMR of compound $\mathbf{4 a - B r}$ in $\mathrm{CDCl}_{3}$

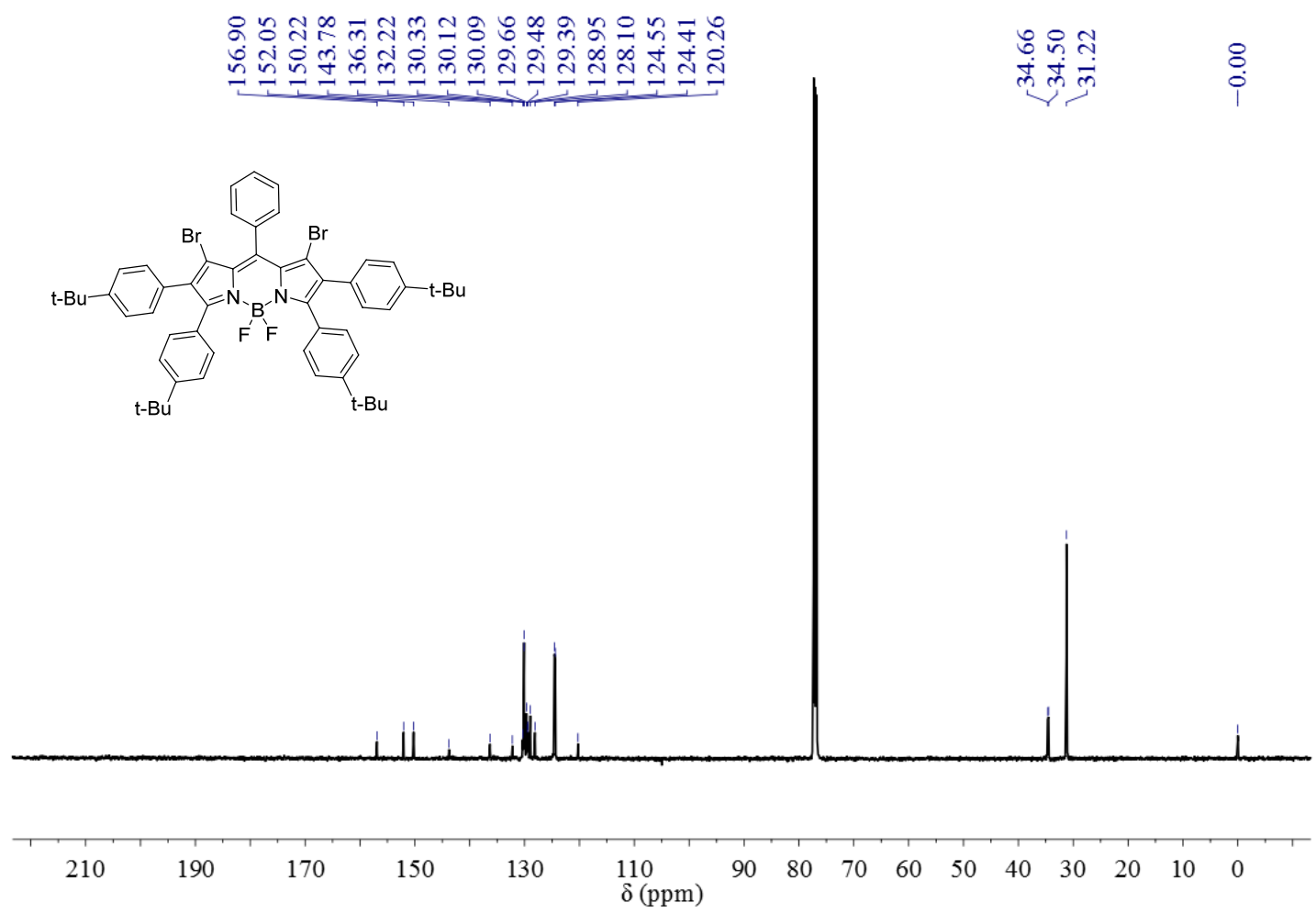

${ }^{13} \mathrm{C}\left\{{ }^{1} \mathrm{H}\right\}$ NMR of compound $\mathbf{4 a}-\mathbf{B r}$ in $\mathrm{CDCl}_{3}$ 

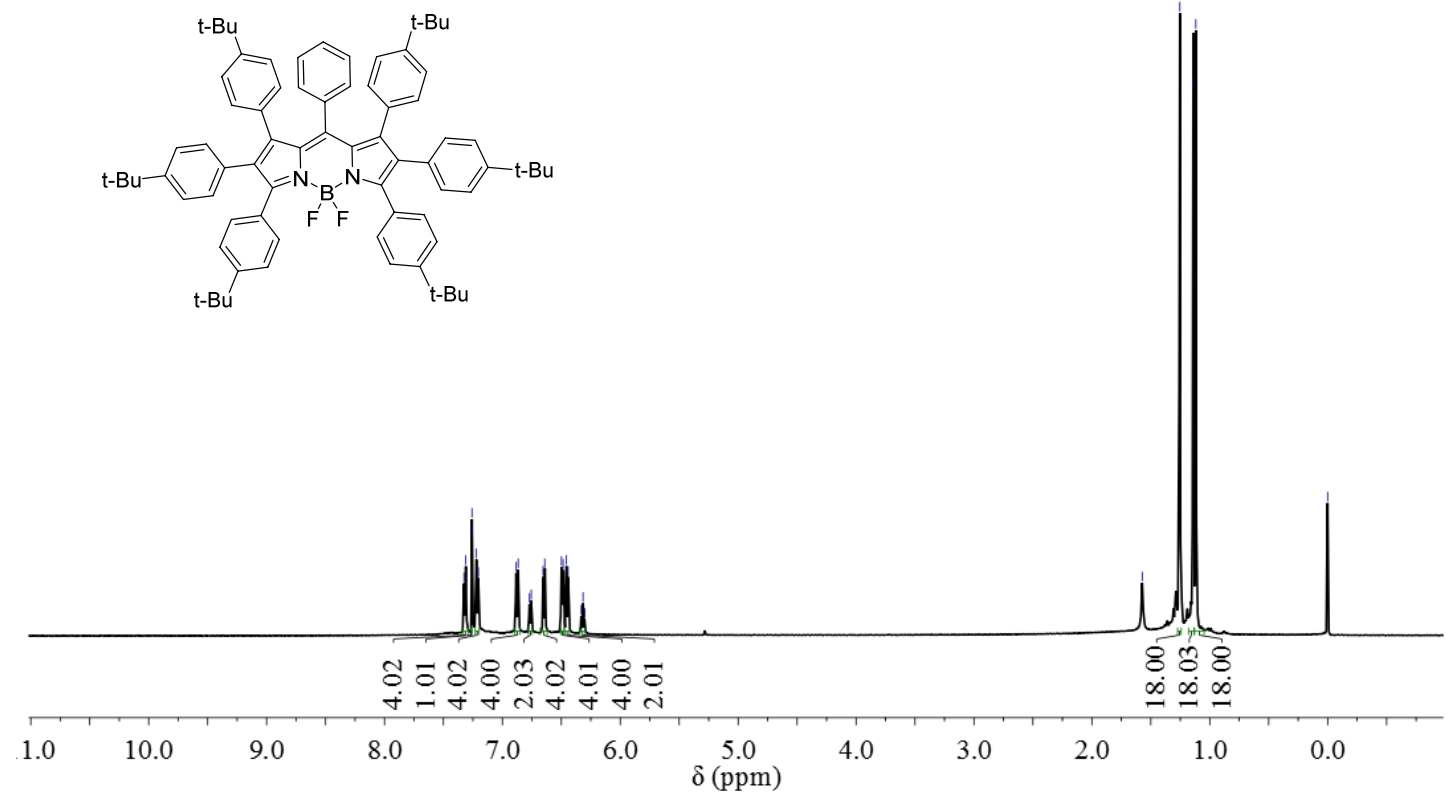

${ }^{1} \mathrm{H}$ NMR of compound $\mathbf{4 b}$ in $\mathrm{CDCl}_{3}$

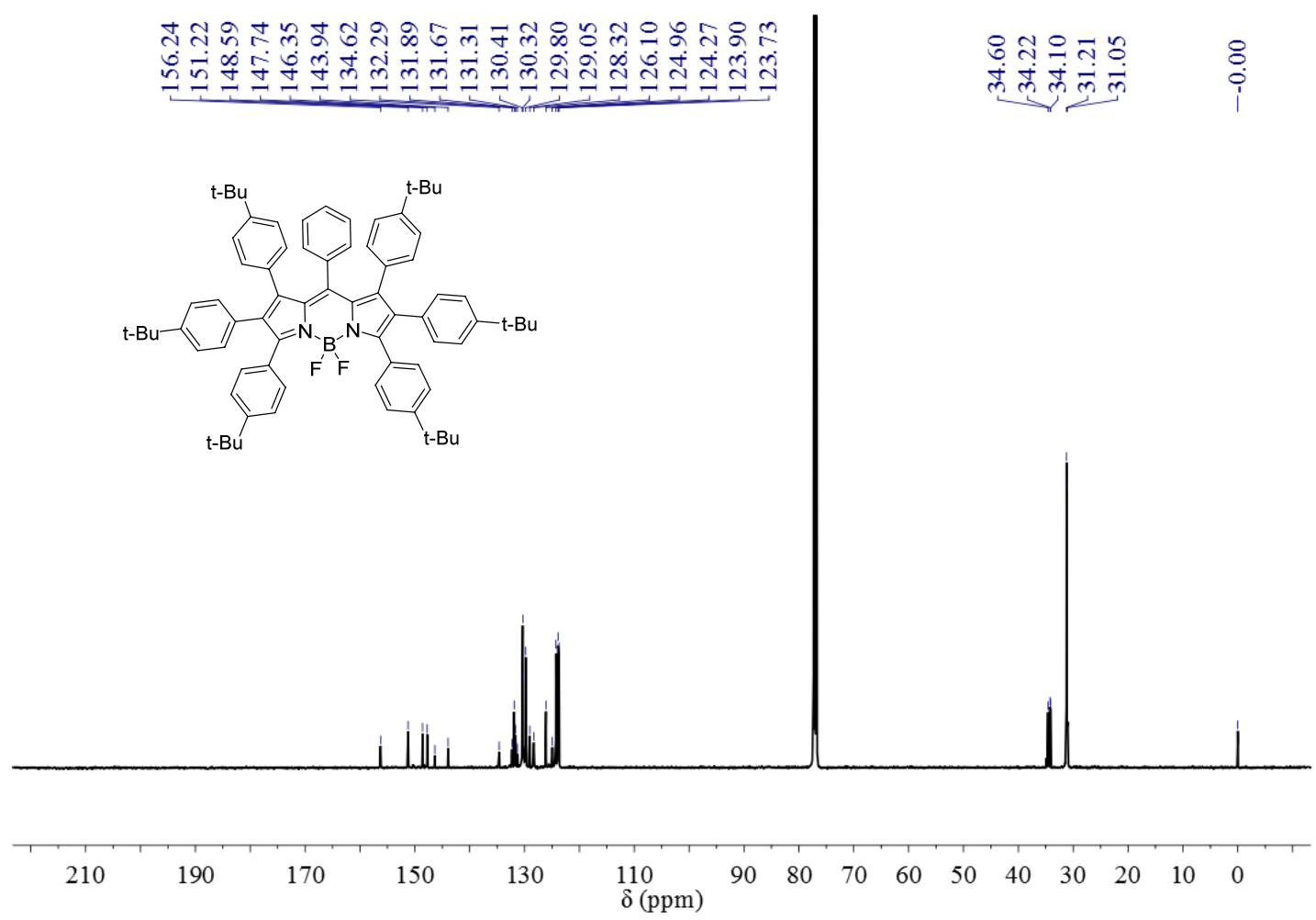

${ }^{13} \mathrm{C}\left\{{ }^{1} \mathrm{H}\right\}$ NMR of compound $\mathbf{4 b}$ in $\mathrm{CDCl}_{3}$ 


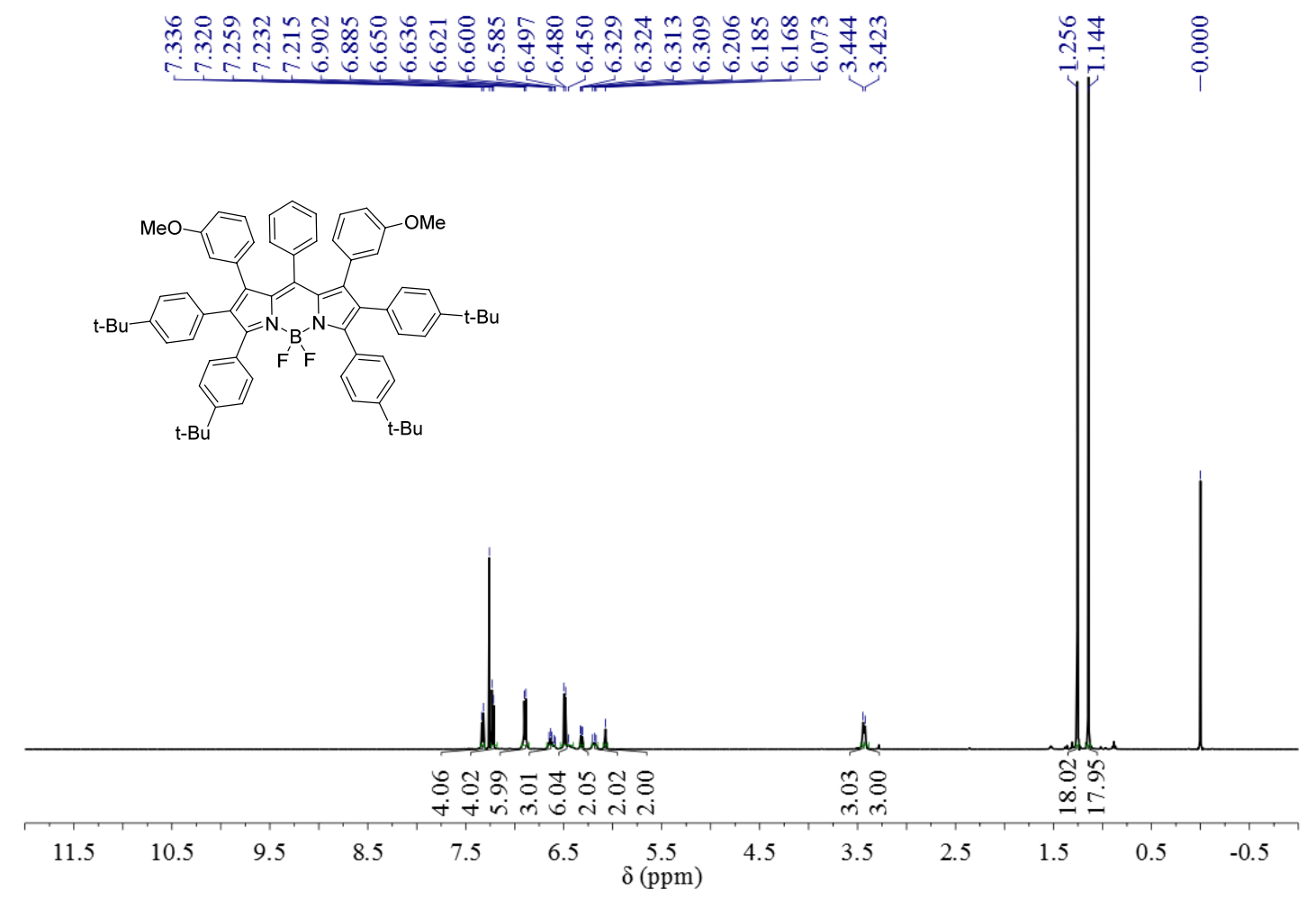

${ }^{1} \mathrm{H}$ NMR of compound $4 \mathrm{c}$ in $\mathrm{CDCl}_{3}$

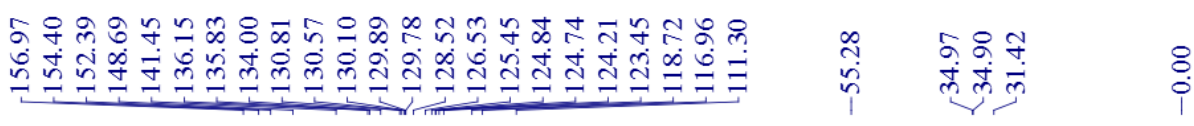

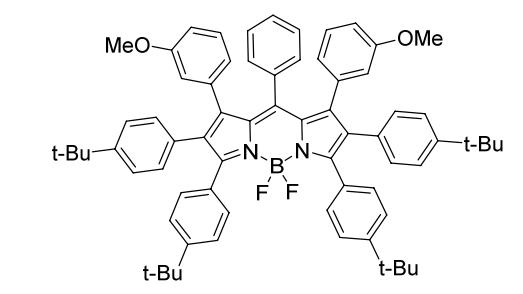

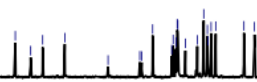

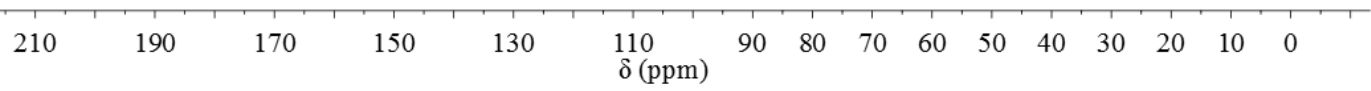

${ }^{13} \mathrm{C}\left\{{ }^{1} \mathrm{H}\right\}$ NMR of compound $4 \mathrm{c}$ in $\mathrm{CDCl}_{3}$ 

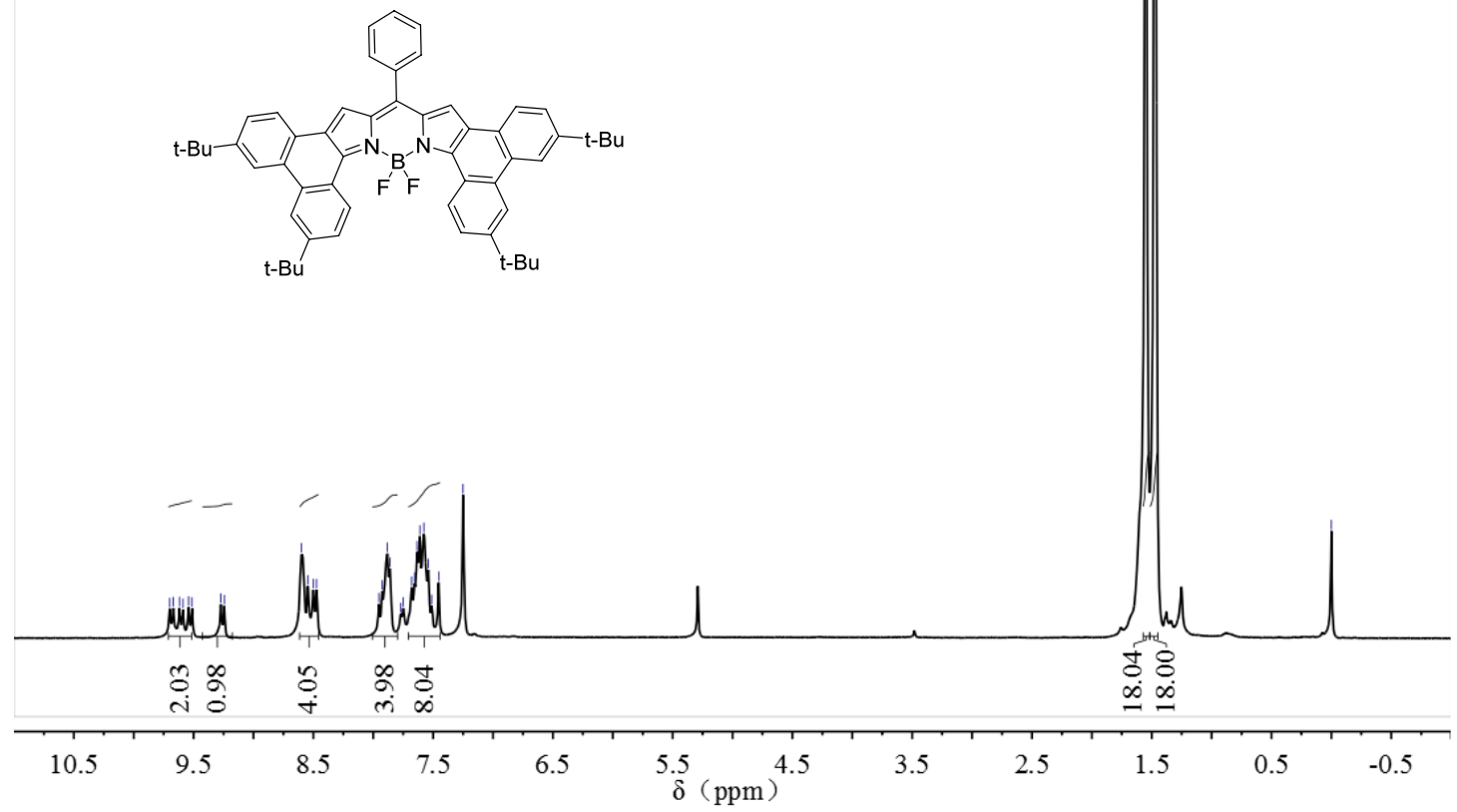

${ }^{1} \mathrm{H}$ NMR of compound $5 \mathbf{a}$ in $\mathrm{CDCl}_{3}$

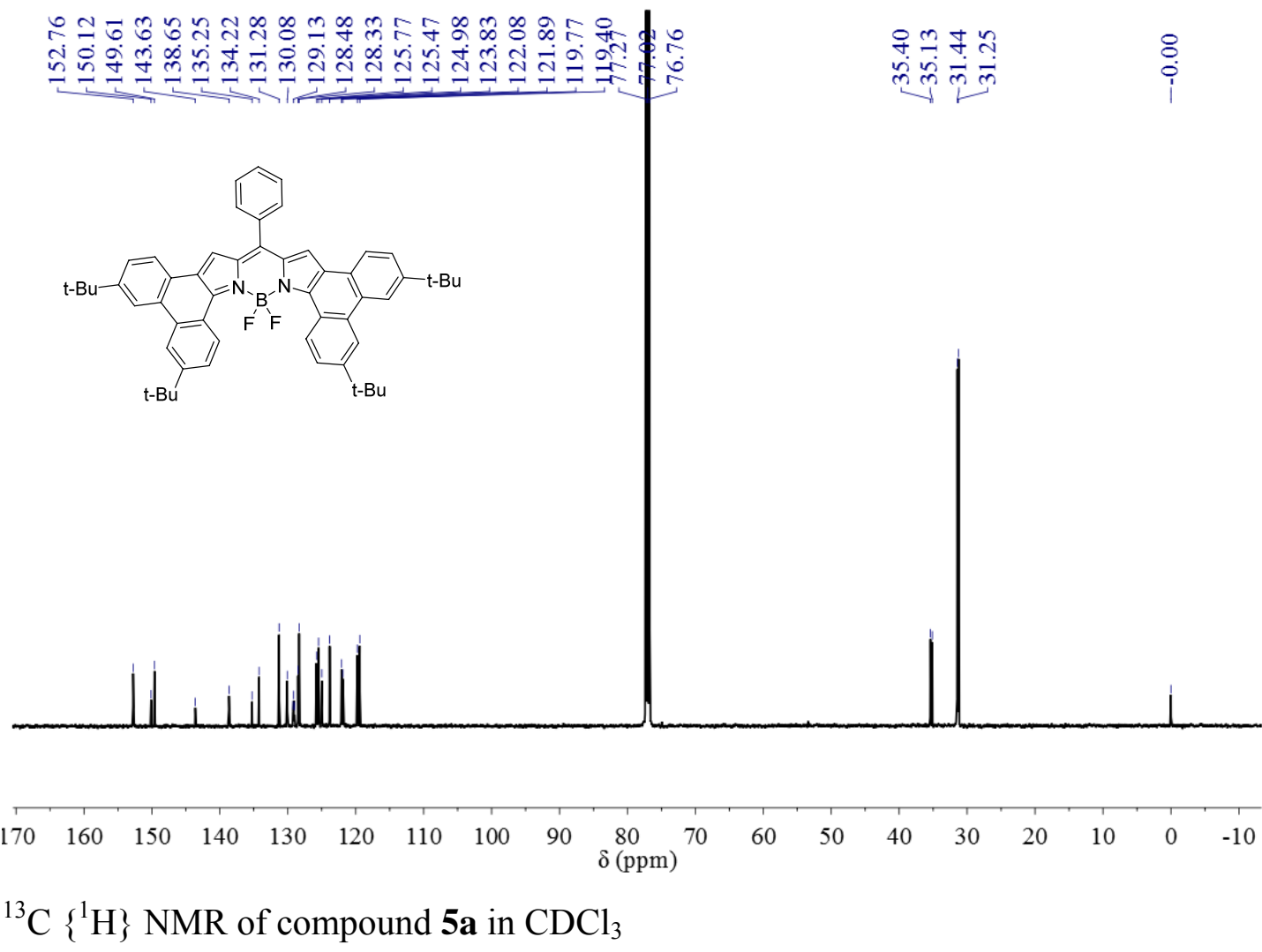




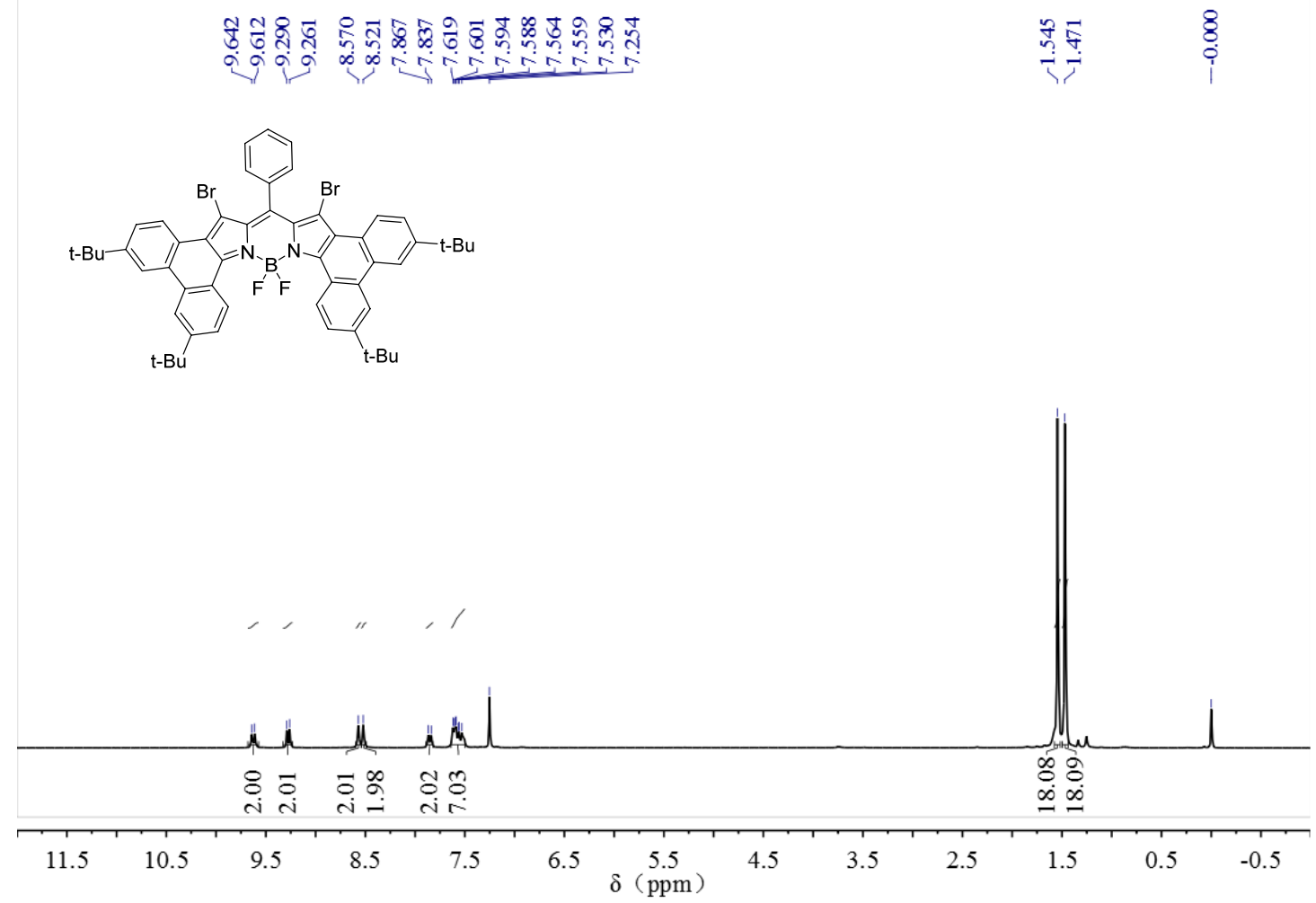

${ }^{1} \mathrm{H} \mathrm{NMR}$ of compound $5 \mathrm{a}-\mathrm{Br}$ in $\mathrm{CDCl}_{3}$

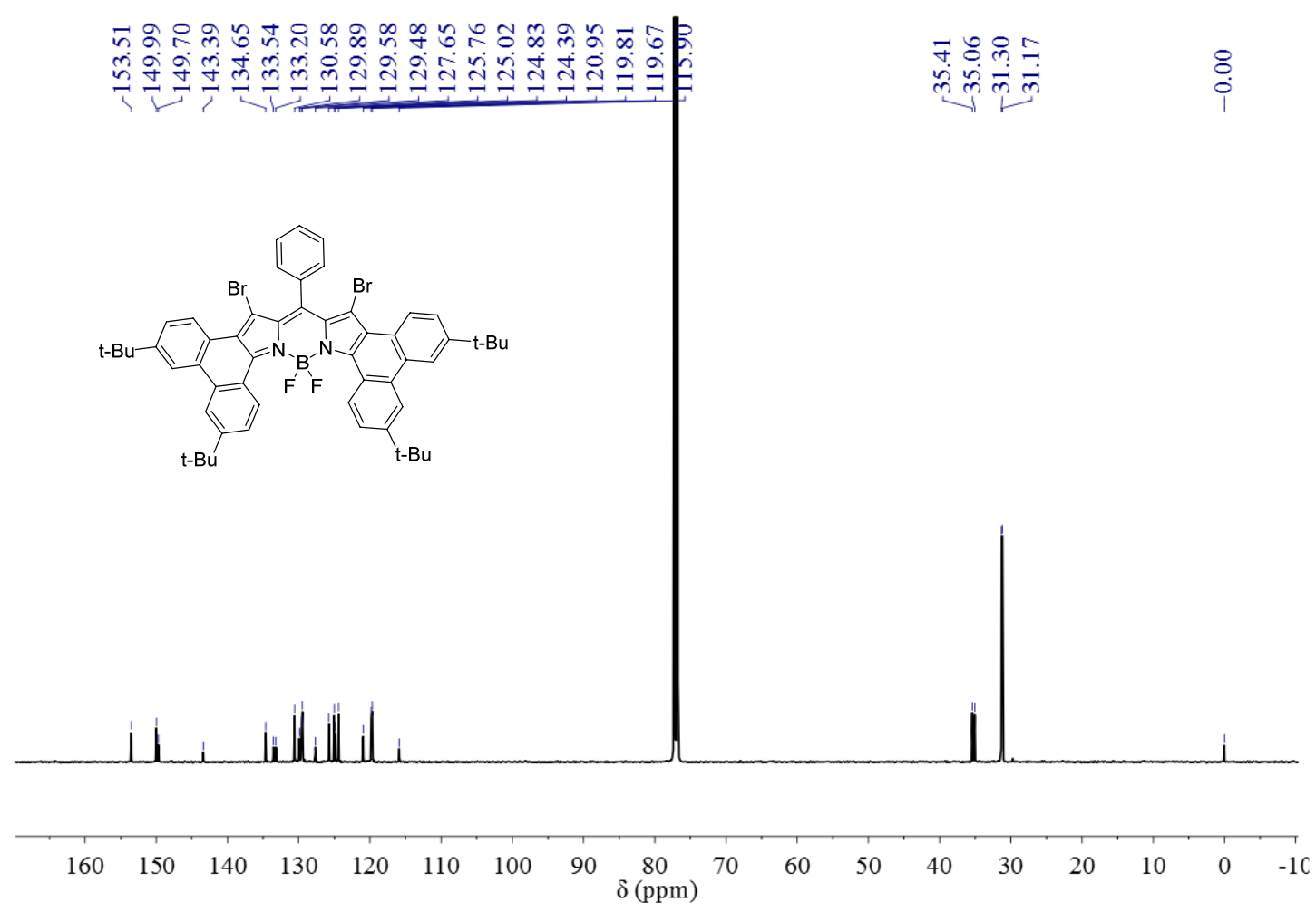

${ }^{13} \mathrm{C}\left\{{ }^{1} \mathrm{H}\right\}$ NMR of compound $\mathbf{5 a}-\mathbf{B r}$ in $\mathrm{CDCl}_{3}$ 


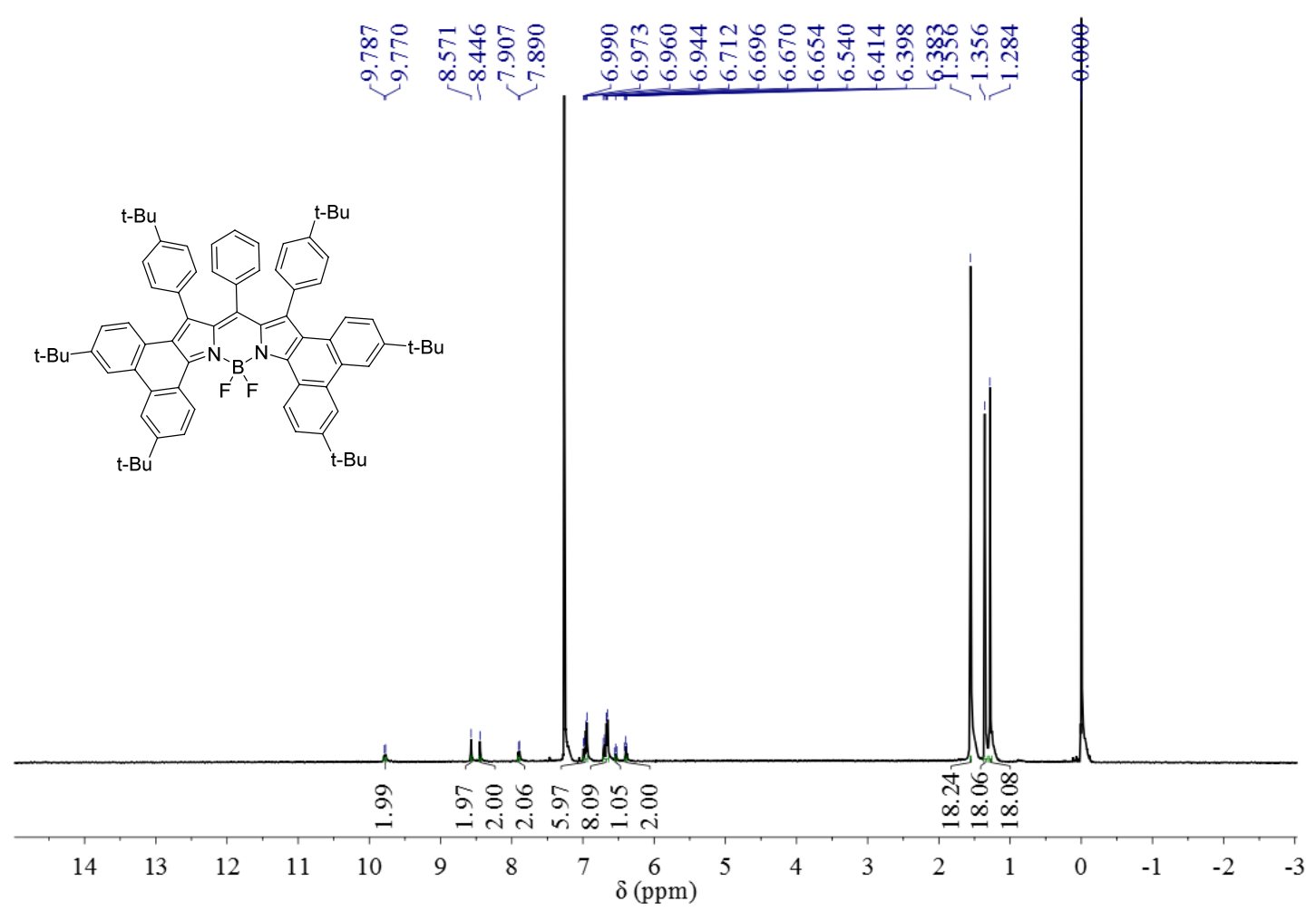

${ }^{1} \mathrm{H} \mathrm{NMR}$ of compound $\mathbf{5 b}$ in $\mathrm{CDCl}_{3}$

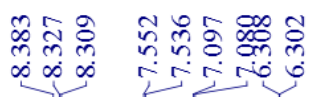

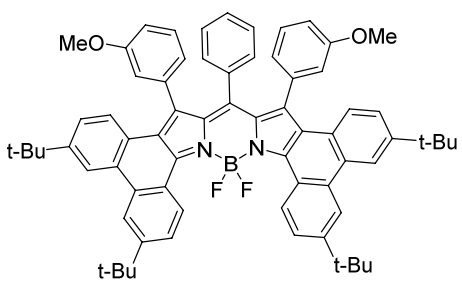

t-Bu

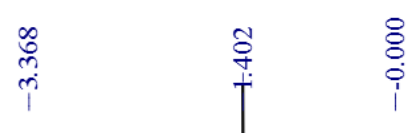

di dillie

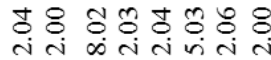

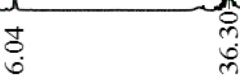

क्र

$\begin{array}{lllllllllllll}11.5 & 10.5 & 9.5 & 8.5 & 7.5 & 6.5 & \begin{array}{c}5.5 \\ \delta(\mathrm{pm})\end{array} & 4.5 & 3.5 & 2.5 & 1.5 & 0.5 & -0.5\end{array}$

${ }^{1} \mathrm{H}$ NMR of compound $\mathbf{5 c}$ in $\mathrm{CDCl}_{3}$ 

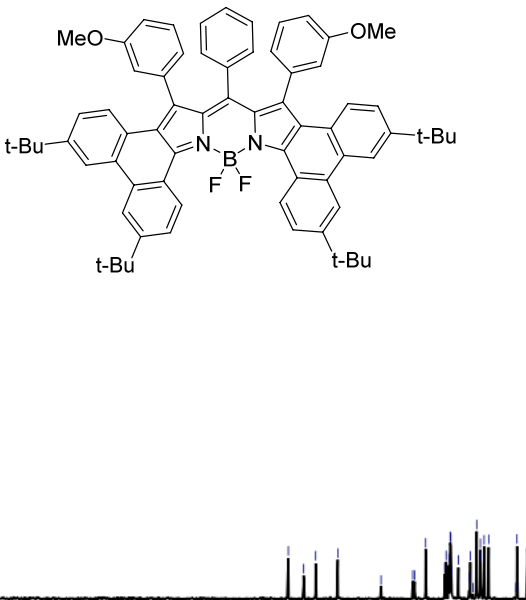

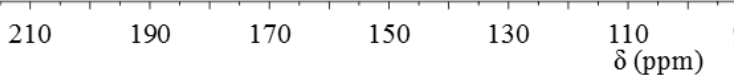

${ }^{13} \mathrm{C}\left\{{ }^{1} \mathrm{H}\right\}$ NMR of compound $5 \mathrm{c}$ in $\mathrm{CDCl}_{3}$

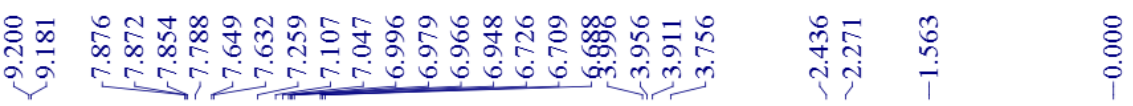

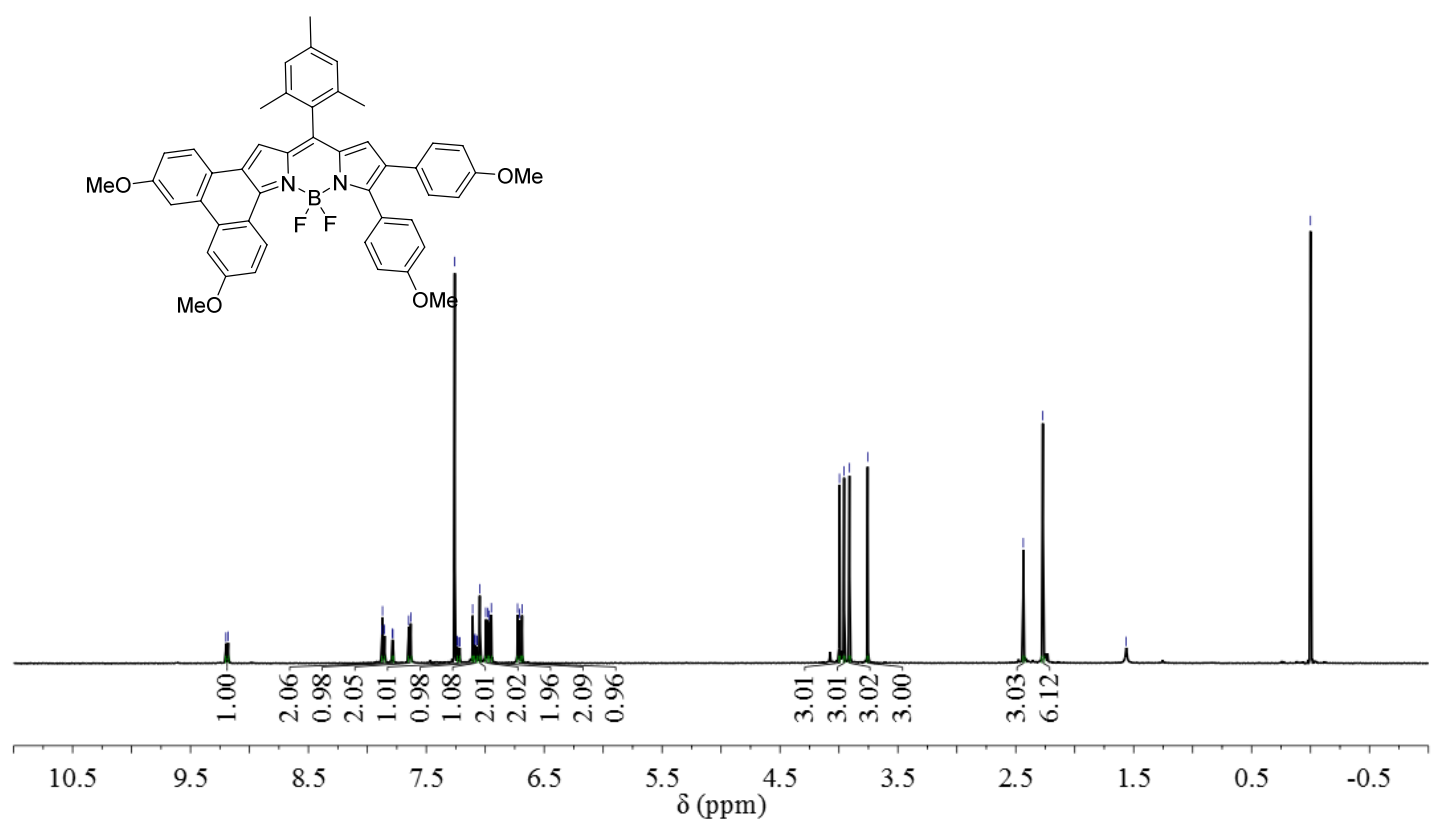

${ }^{1} \mathrm{H}$ NMR of compound 6 in $\mathrm{CDCl}_{3}$ 


\section{Copies of HRMS}

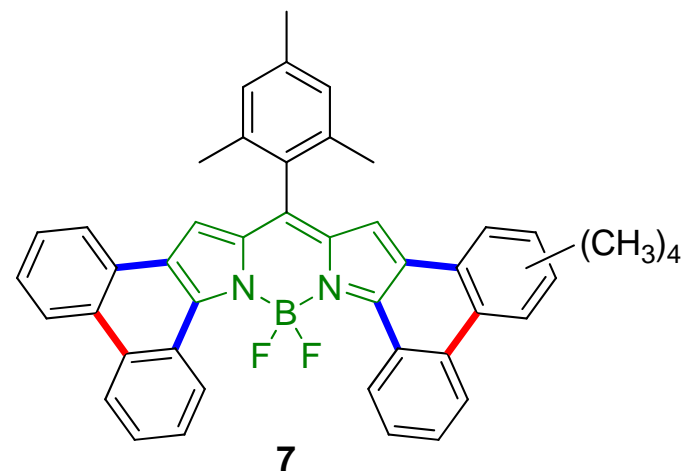

(mixtures of isomers).

20141230 APCHFYM-9 \#4 RT: 0.06 AV: 1 NL: 1.32ES

T: FTMS + c APCl corona Full ms [200.00-1000.00]

667.30927
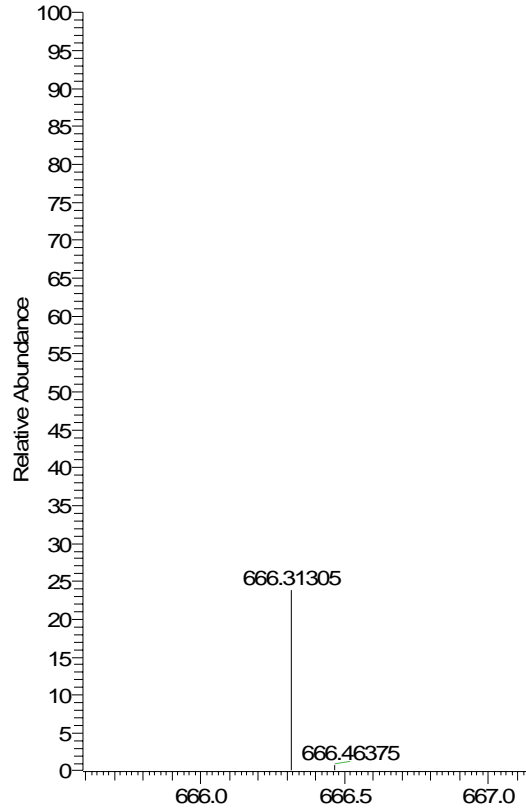

667.

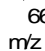

668.31268

Figure S24. HRMS data of 7 (mixtures of isomers). HRMS (APCI) Calcd. for $\mathrm{C}_{46} \mathrm{H}_{38} \mathrm{BF}_{2} \mathrm{~N}_{2}[\mathrm{M}+\mathrm{H}]^{+}$, 667.3096, found 667.3093. 


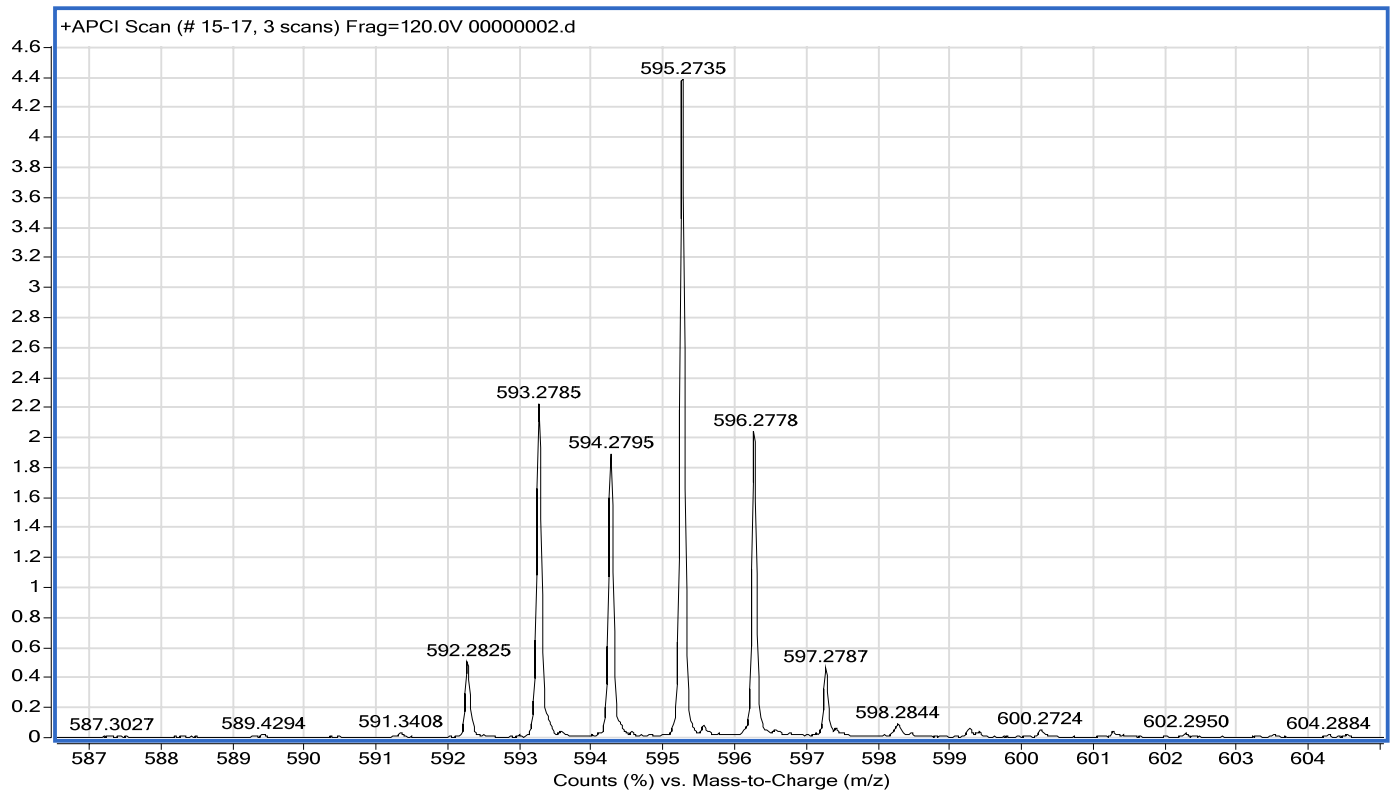

HRMS for 2a

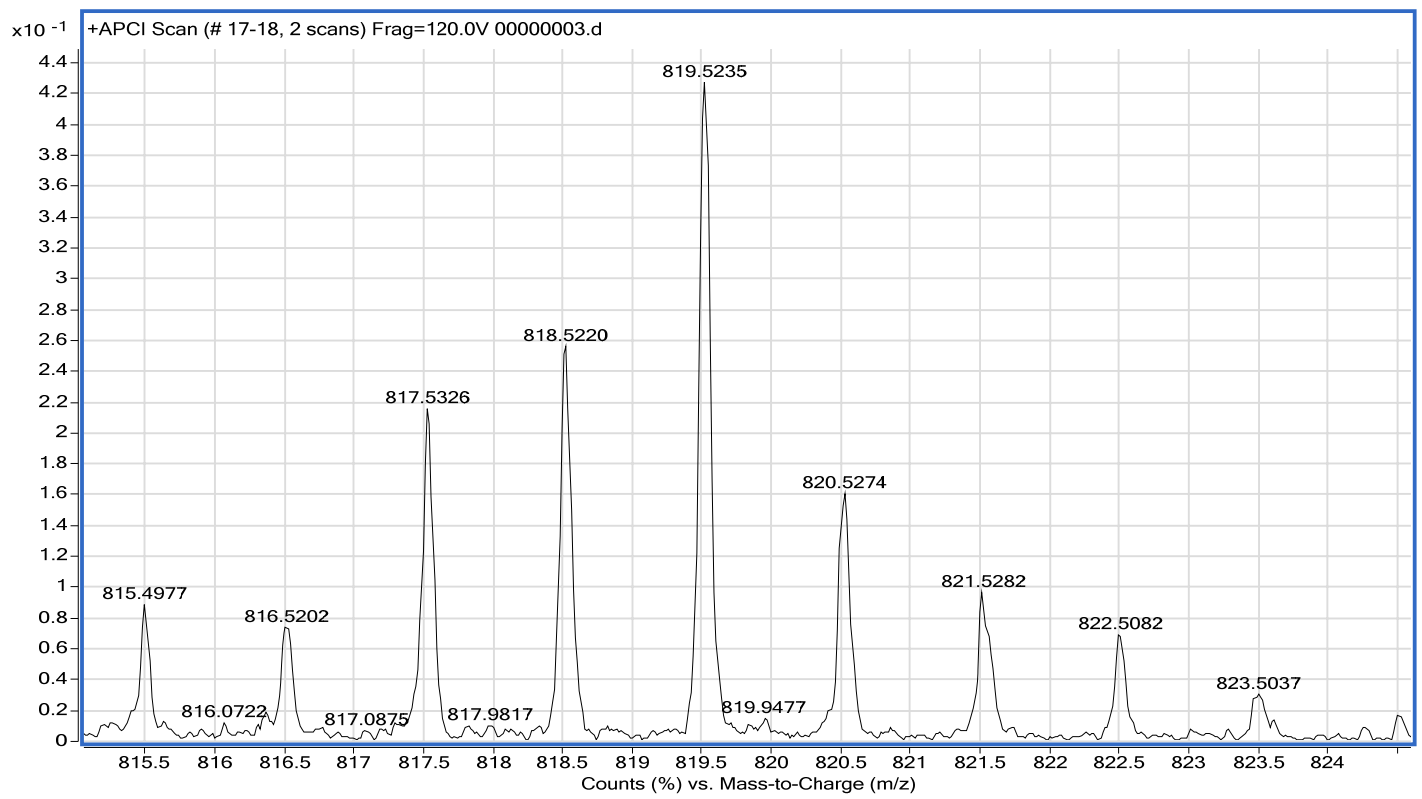

HRMS for $\mathbf{2 b}$ 


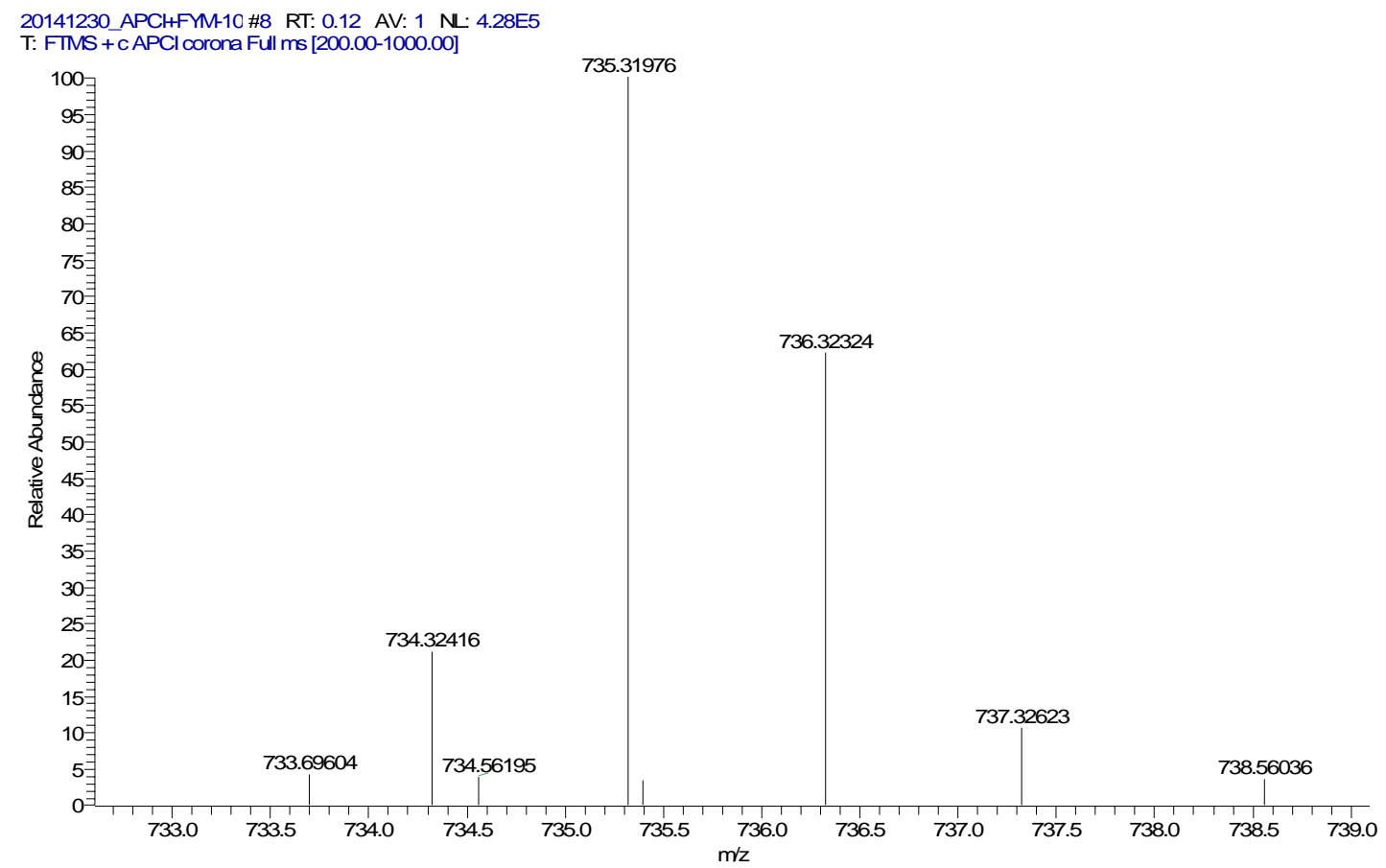

\section{HRMS for 2c}

20141230_APCHFYM-18\#7 RT: 0.11 AV: 1 NL: 1.93E6

T: FTMS + c APCl corona Full ms [200.00-1000.00]

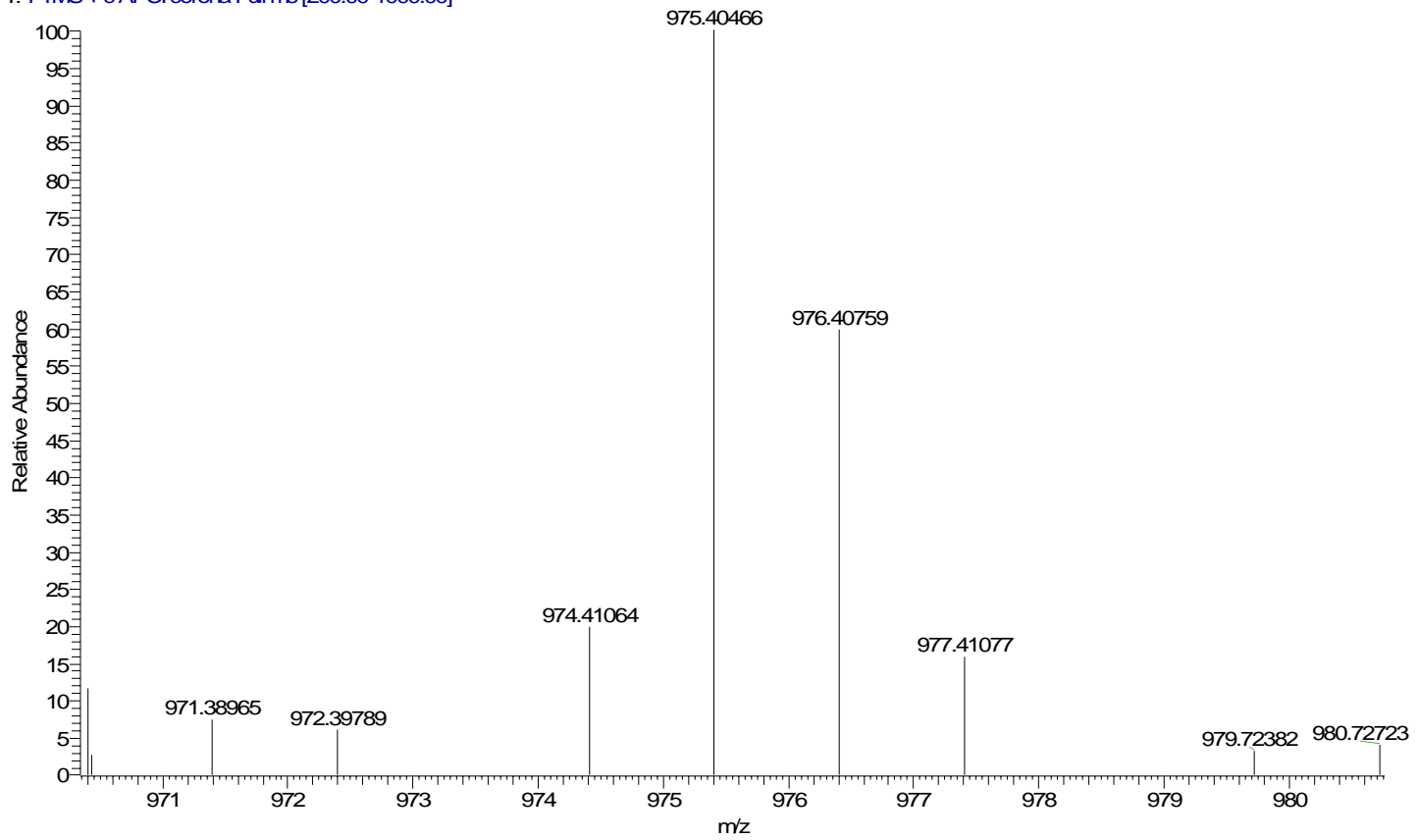

\section{HRMS for 2d}




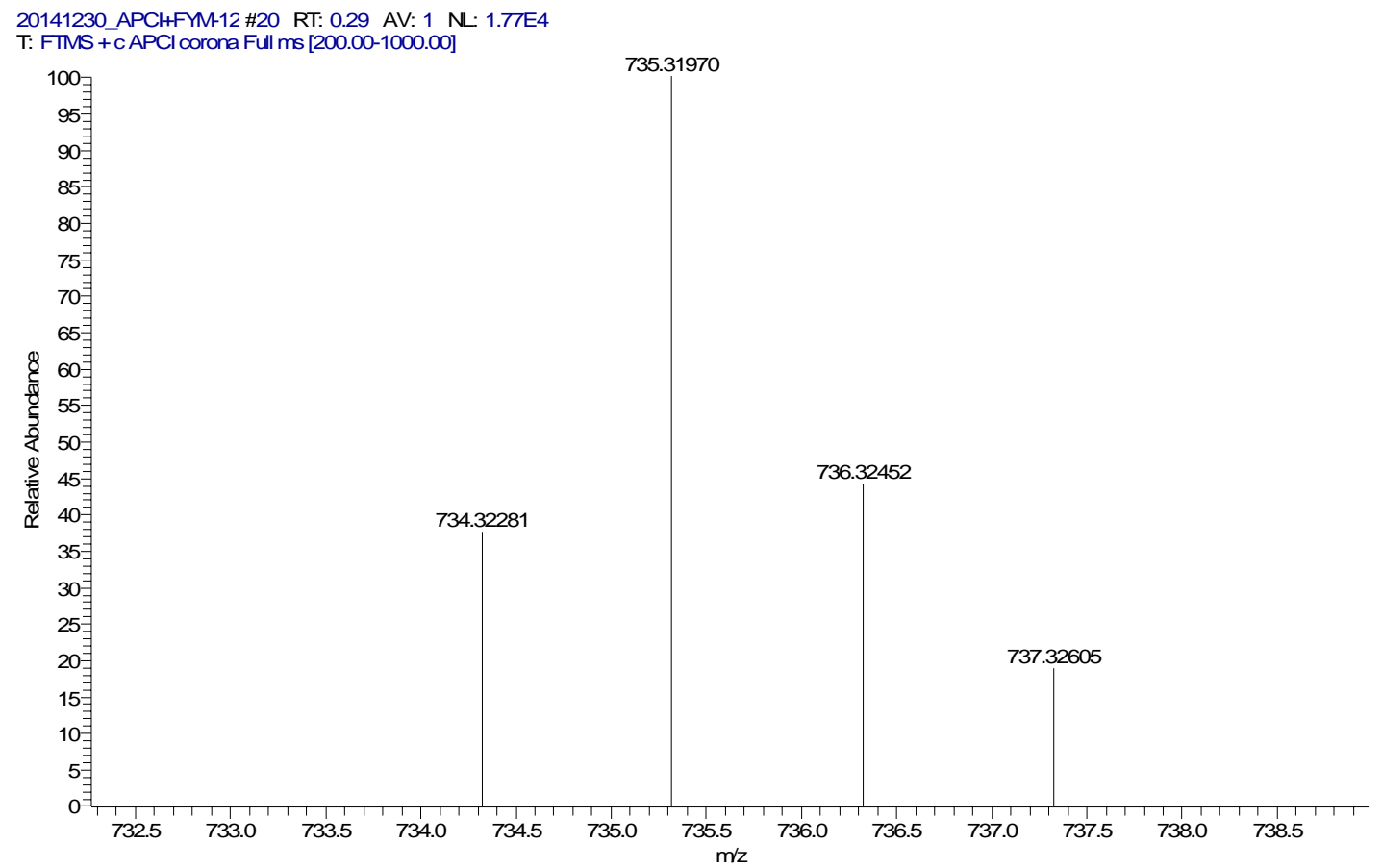

\section{HRMS for $\mathbf{2 e}$}

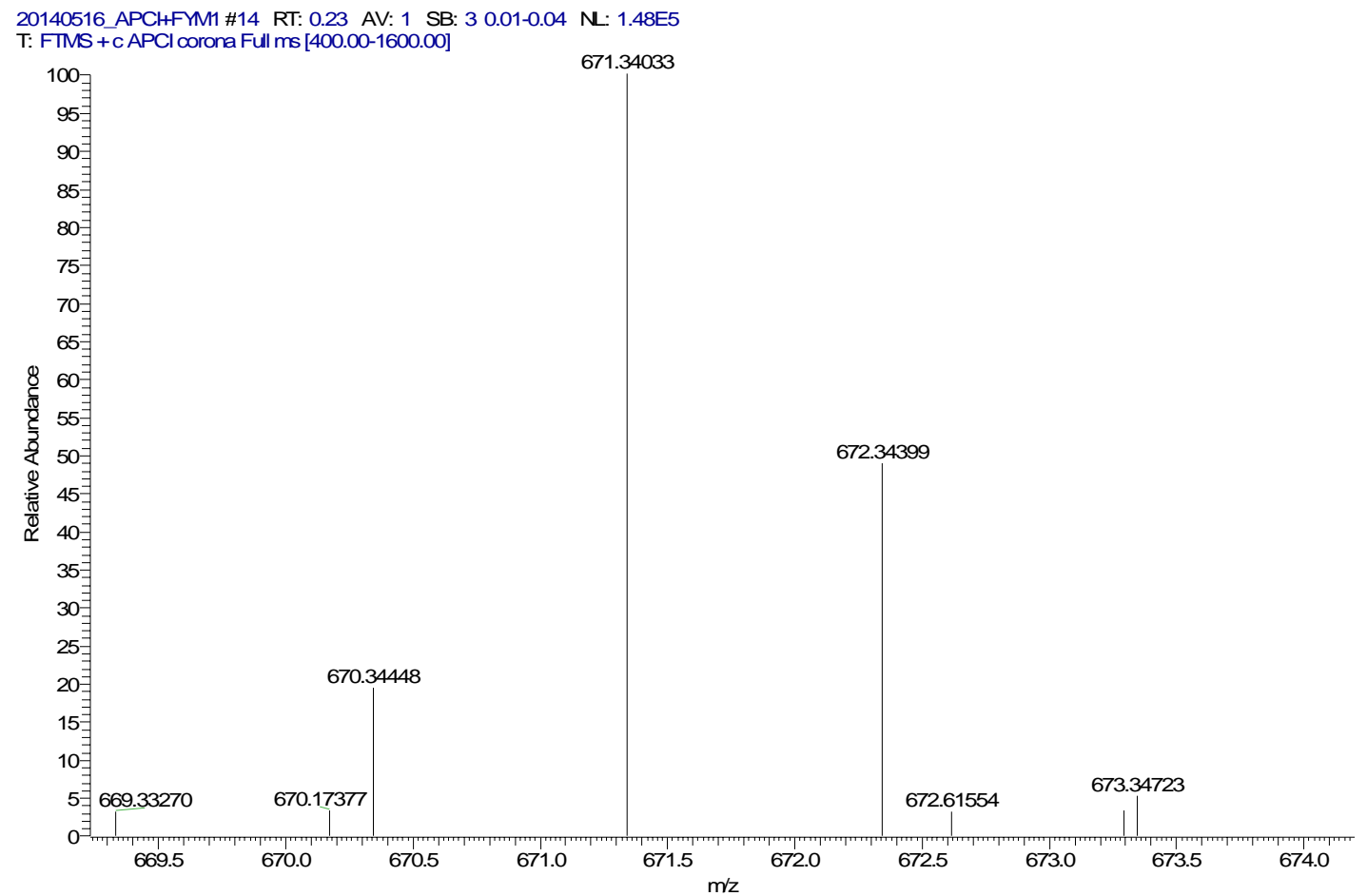

HRMS for $\mathbf{2 f}$ 


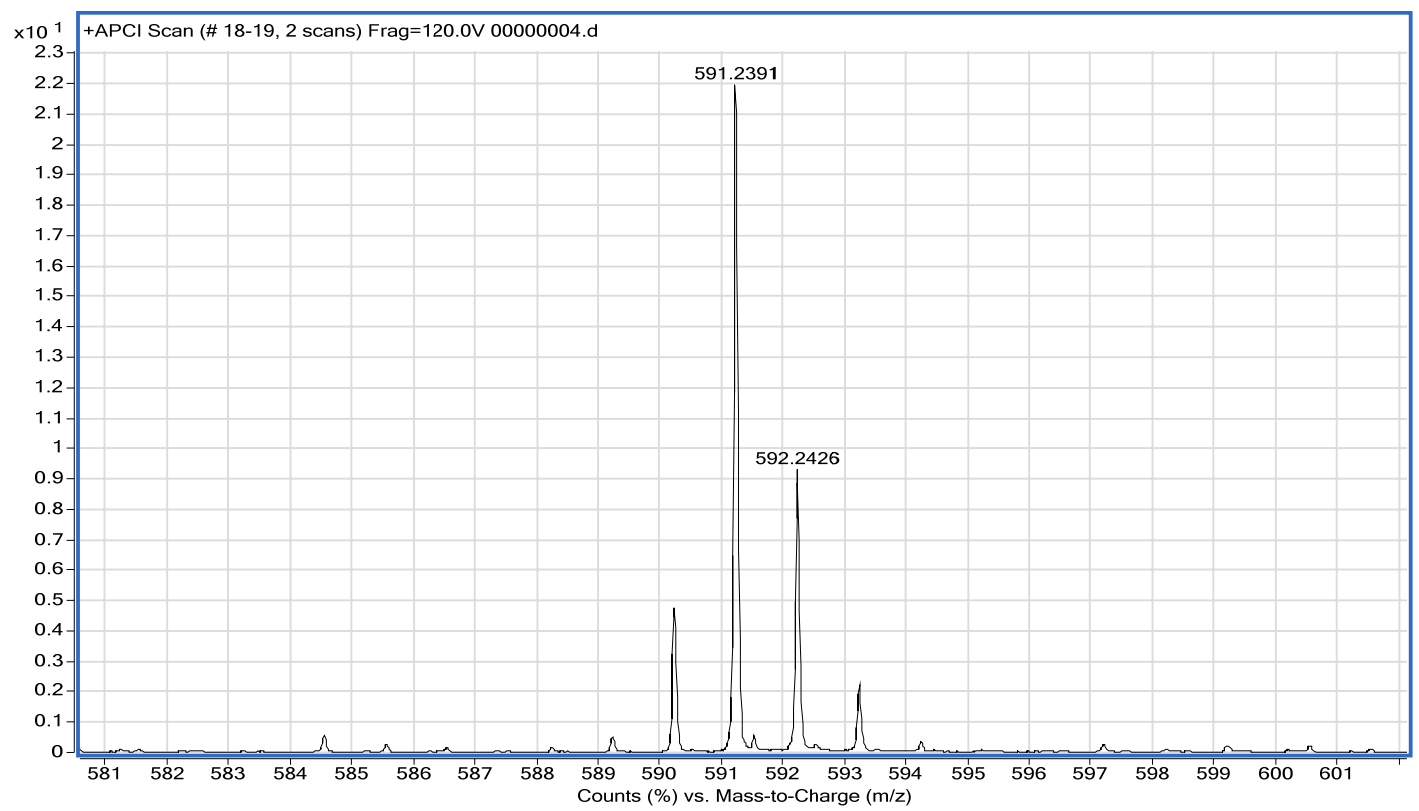

HRMS for 3a

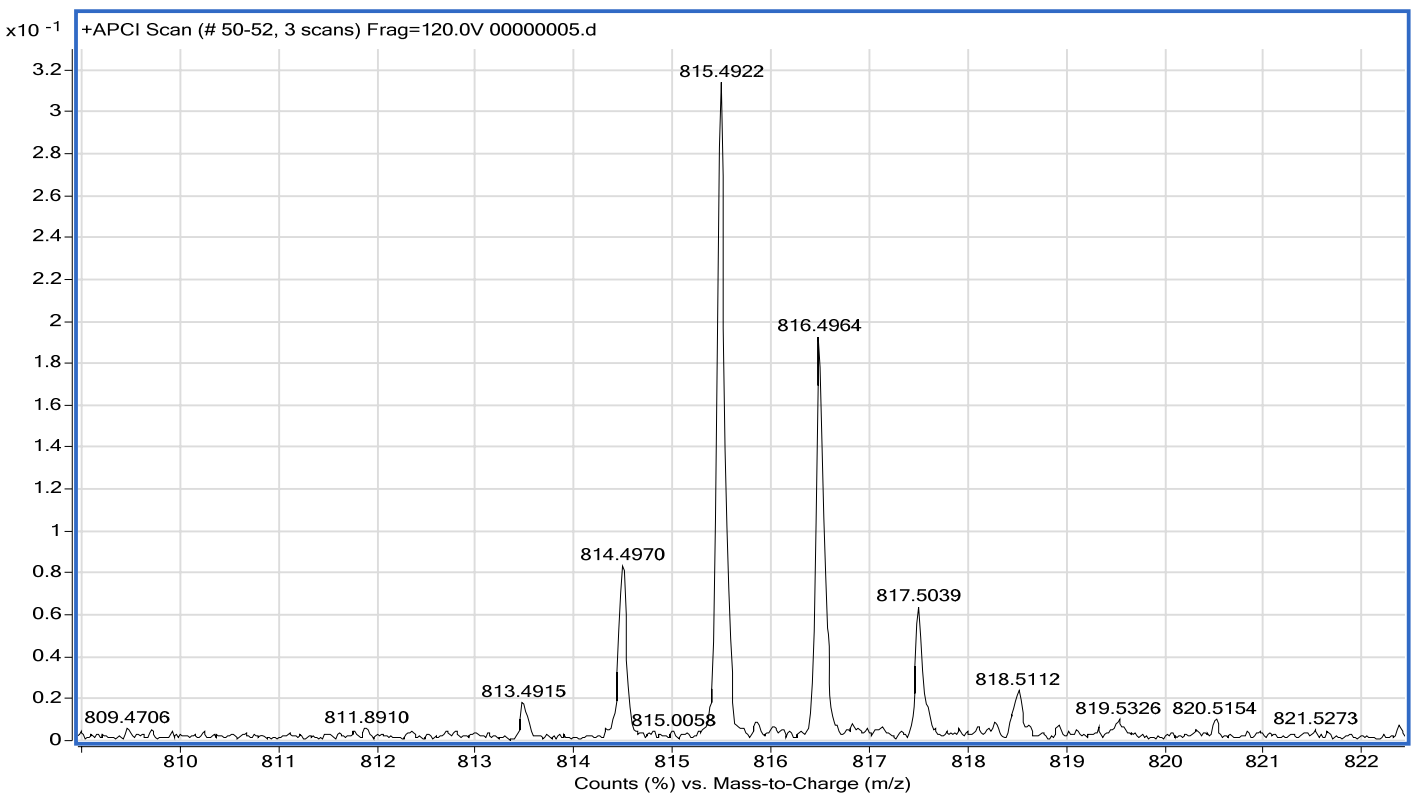

HRMS for $\mathbf{3 b}$ 


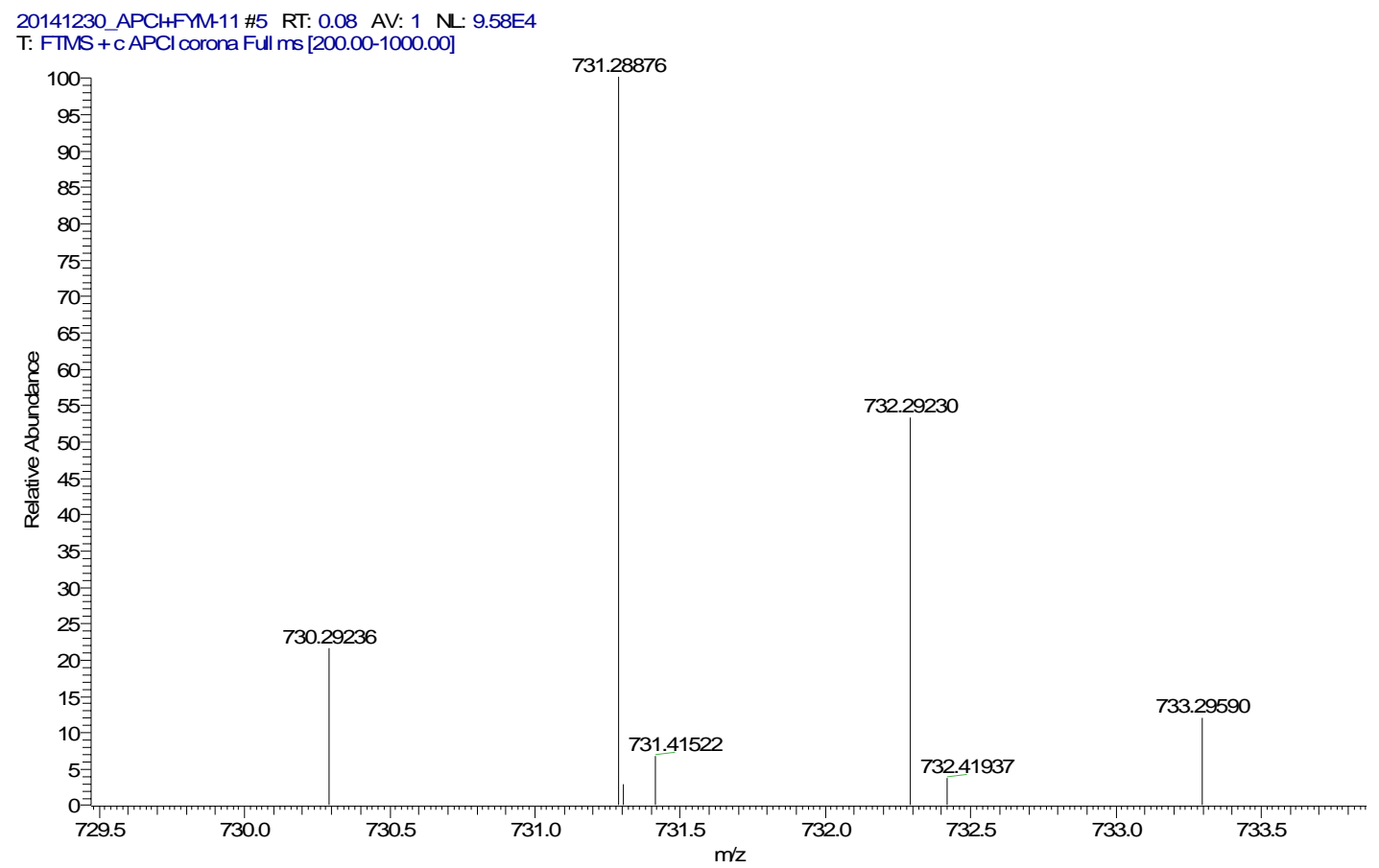

\section{HRMS for 3c}

20141230_APCHFYM-20 \#10 RT: 0.15 AV: 1 NL: 4.65E7 T: FTMS + c APCl corona Full ms [200.00-1000.00]

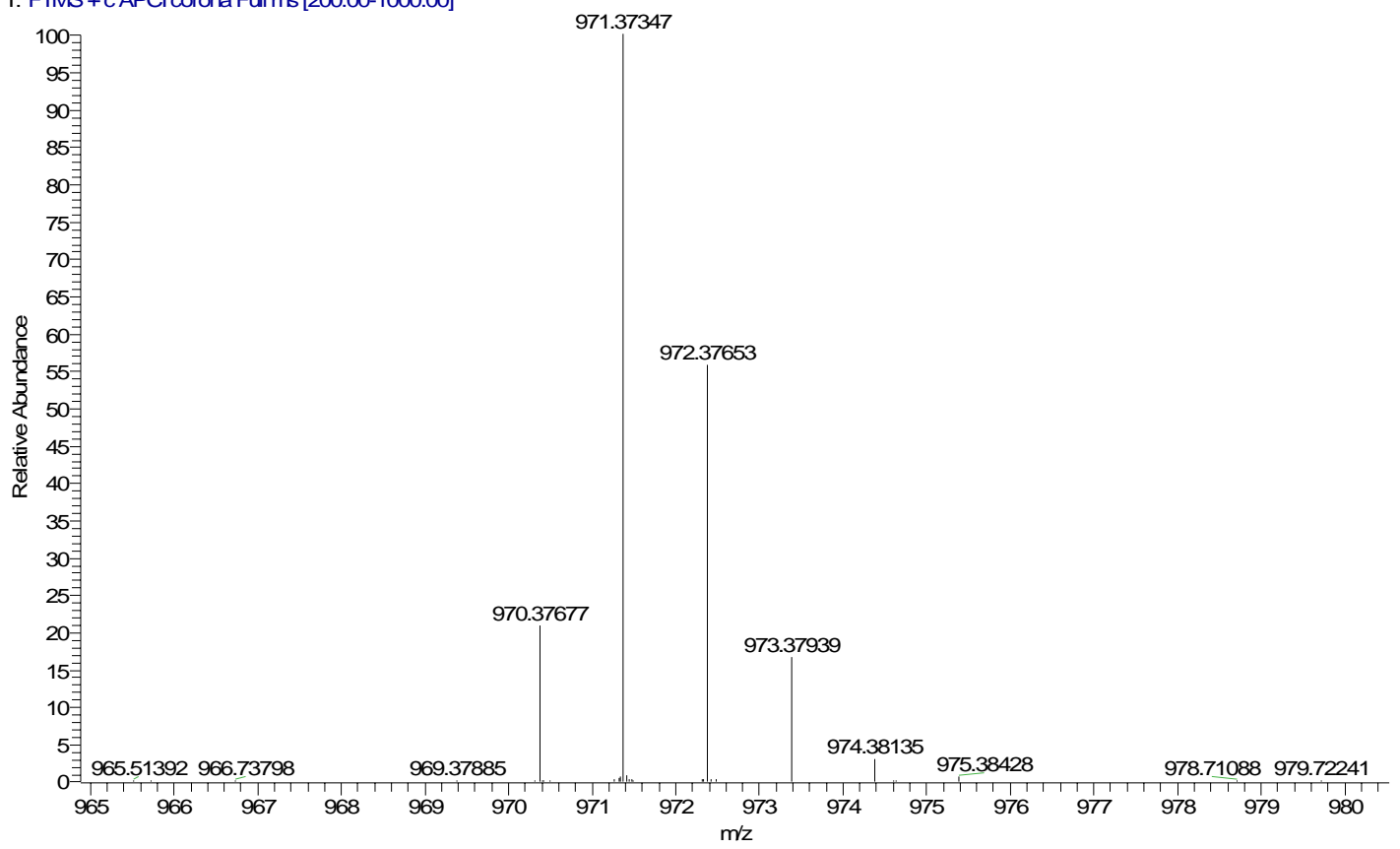

\section{HRMS for 3d}




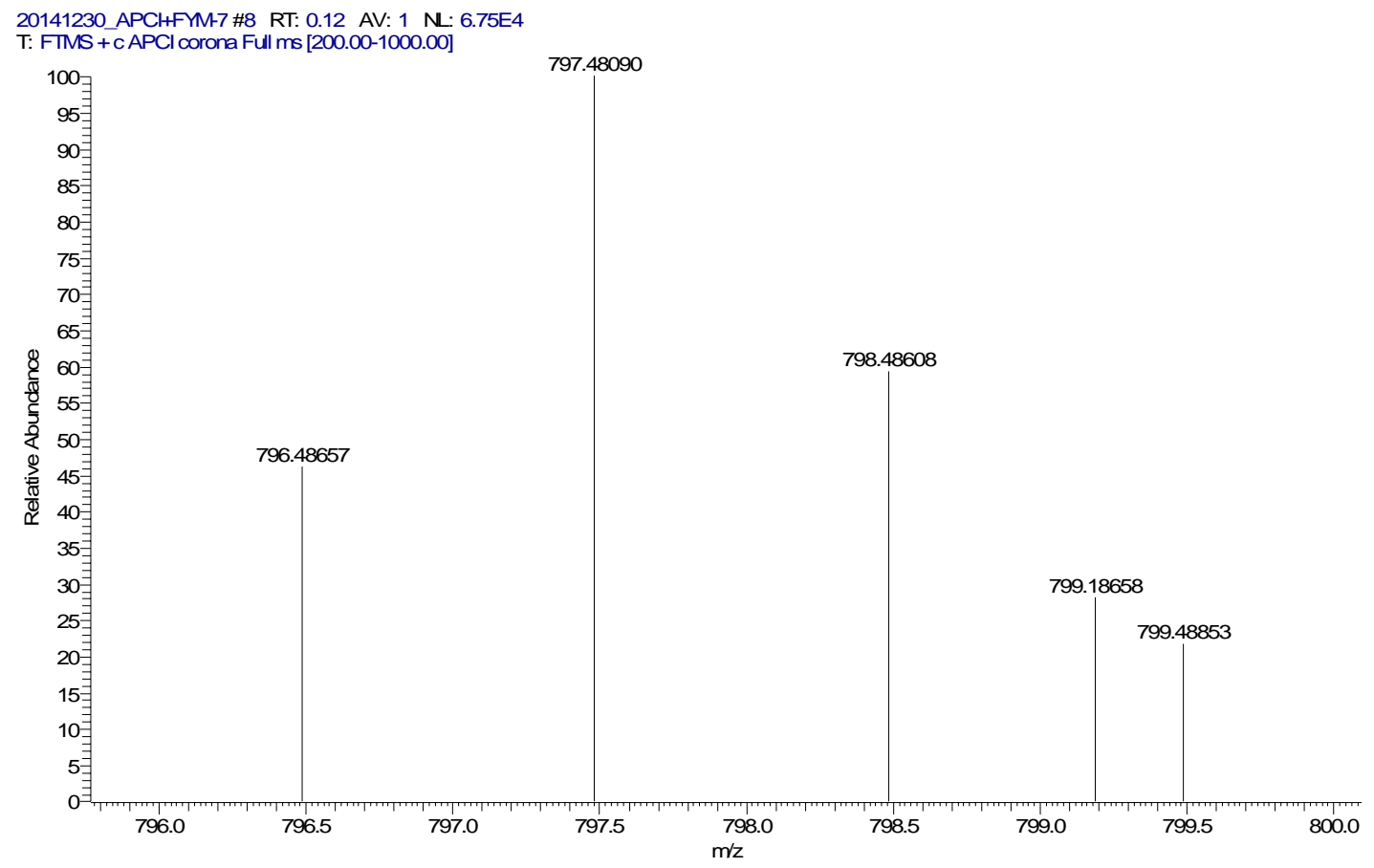

\section{HRMS for 4a}

20141231_APCHFYM-1 \#34 RT: 0.54 AV: 1 SB: 3 0.01-0.04 NL: 1.62E4 T: FTMS + c APCl corona Full ms [800.00-1200.00]

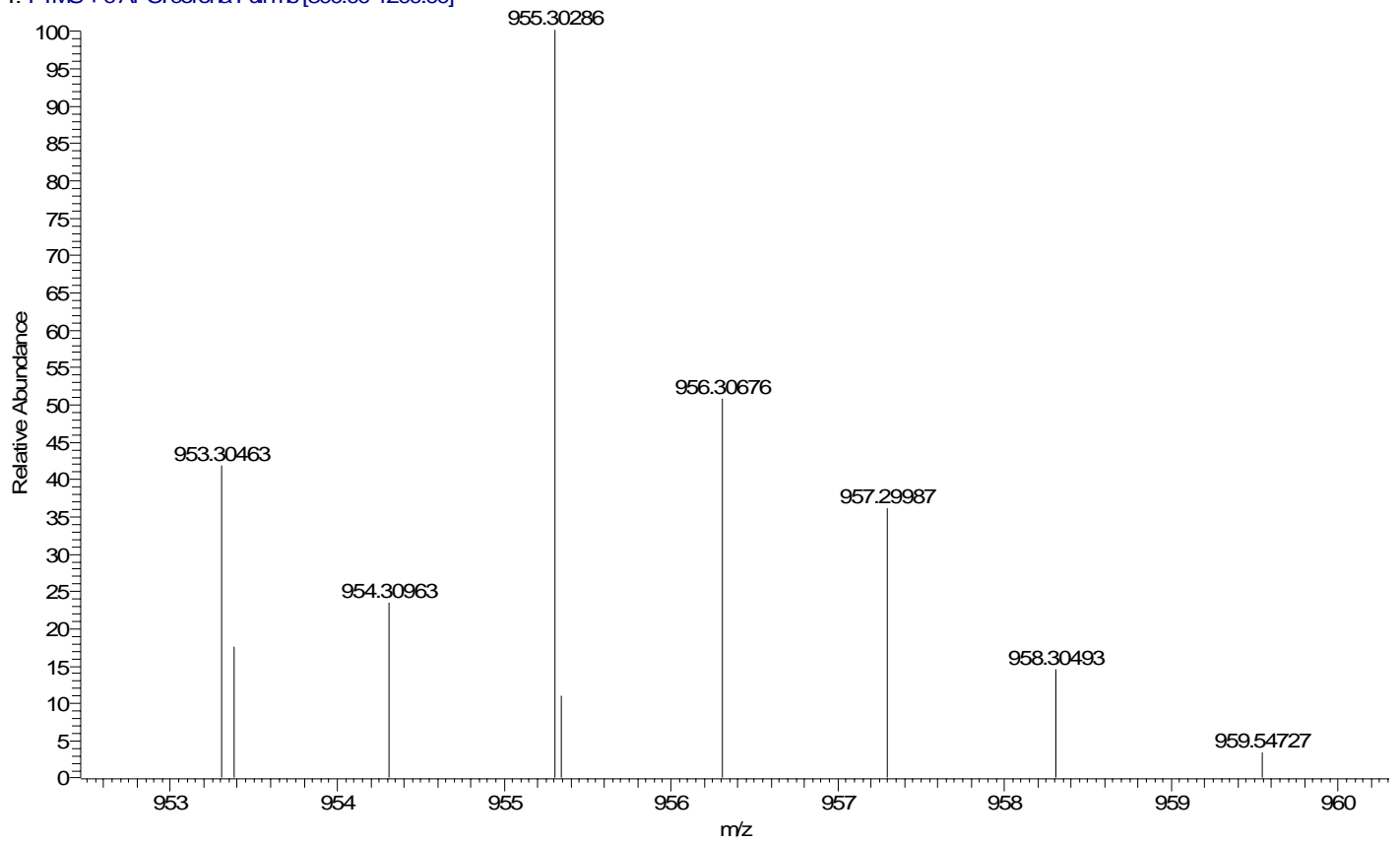

HRMS for 4a-Br 


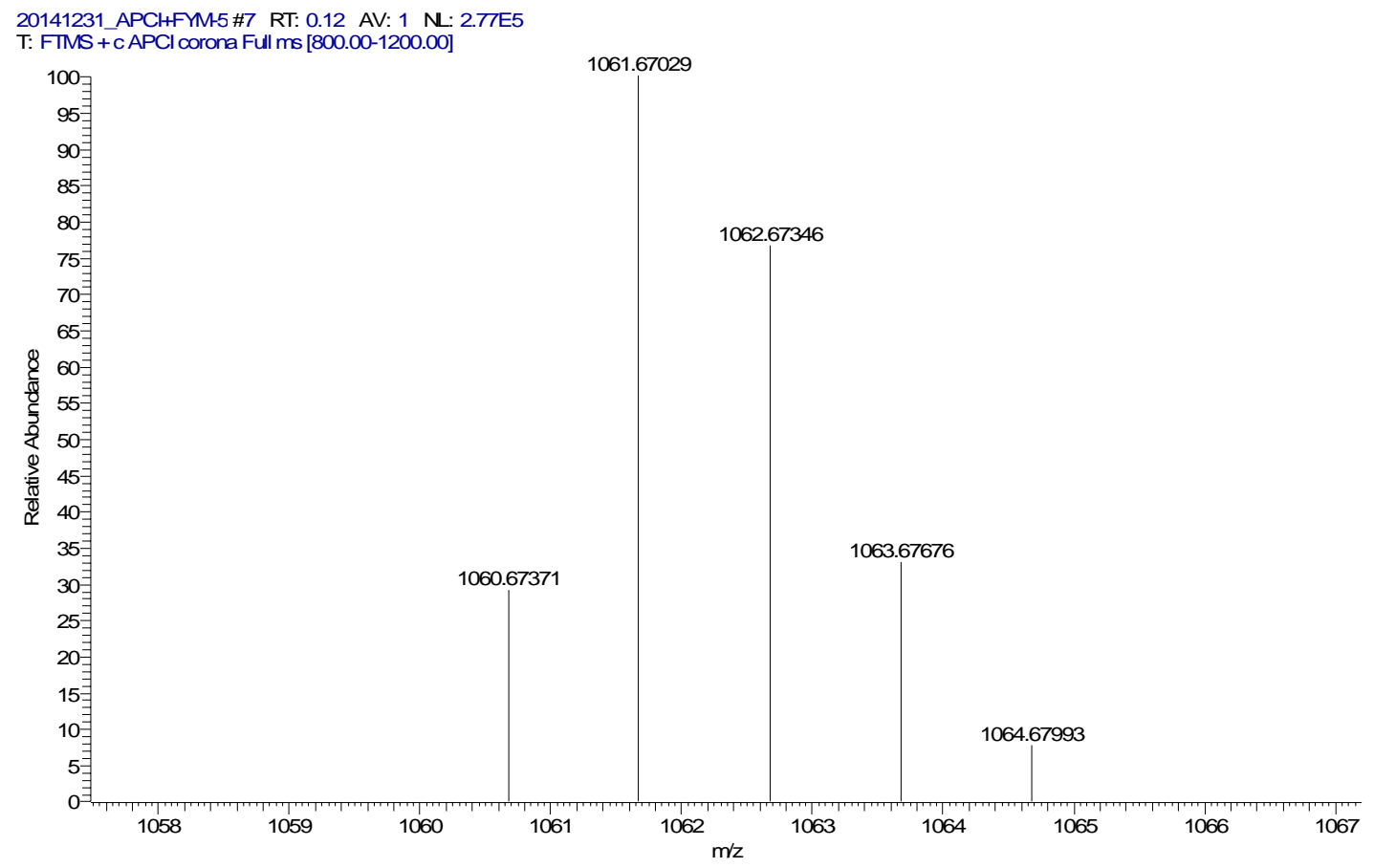

\section{HRMS for $\mathbf{4 b}$}

20141231_APCHFYM-3 \#45 RT: 0.85 AV: 1 SB: 3 0.01-0.04 NL: 3.83E3 T: FTMS + c APCl corona Full ms [800.00-1200.00]

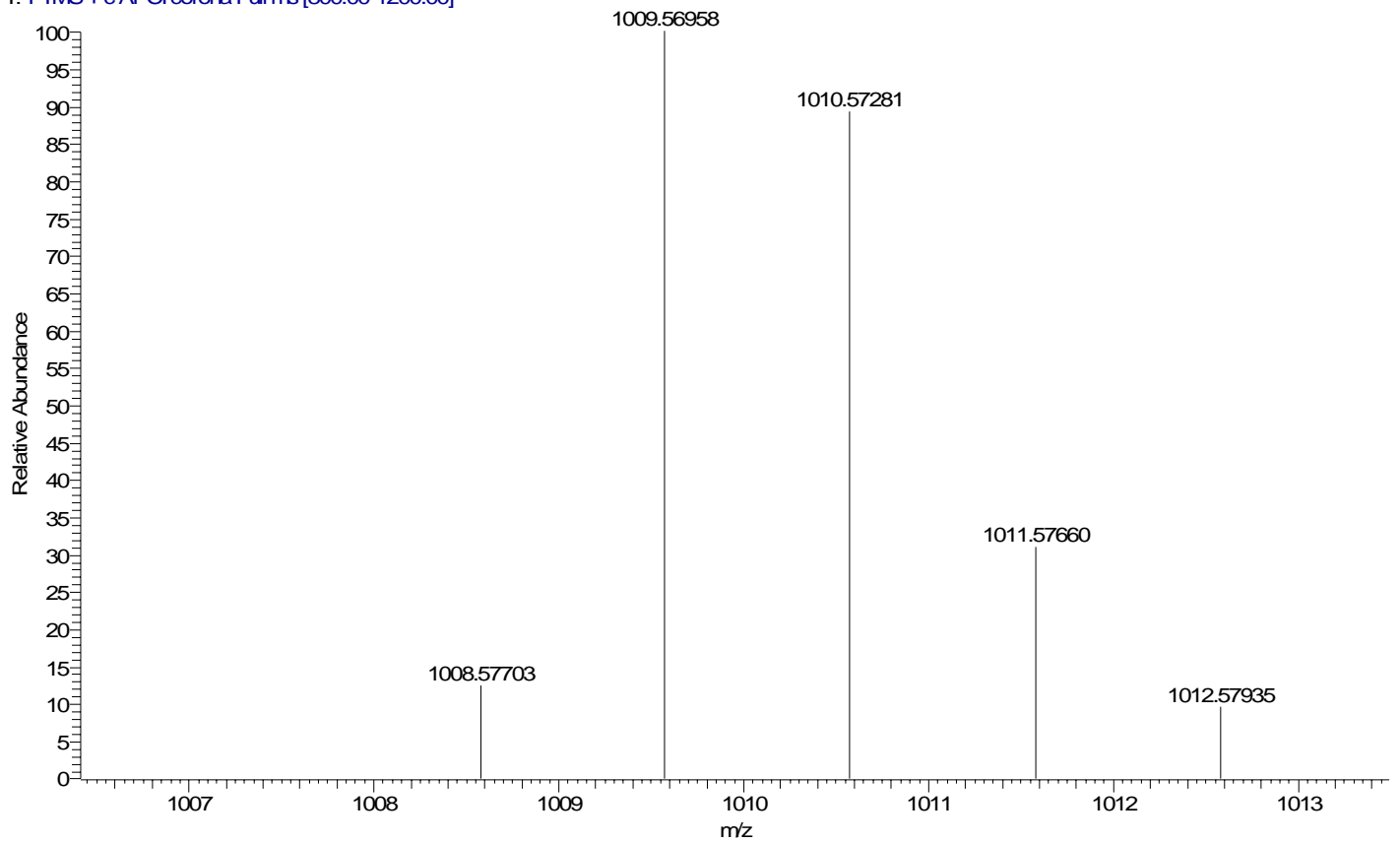

HRMS for 4c 


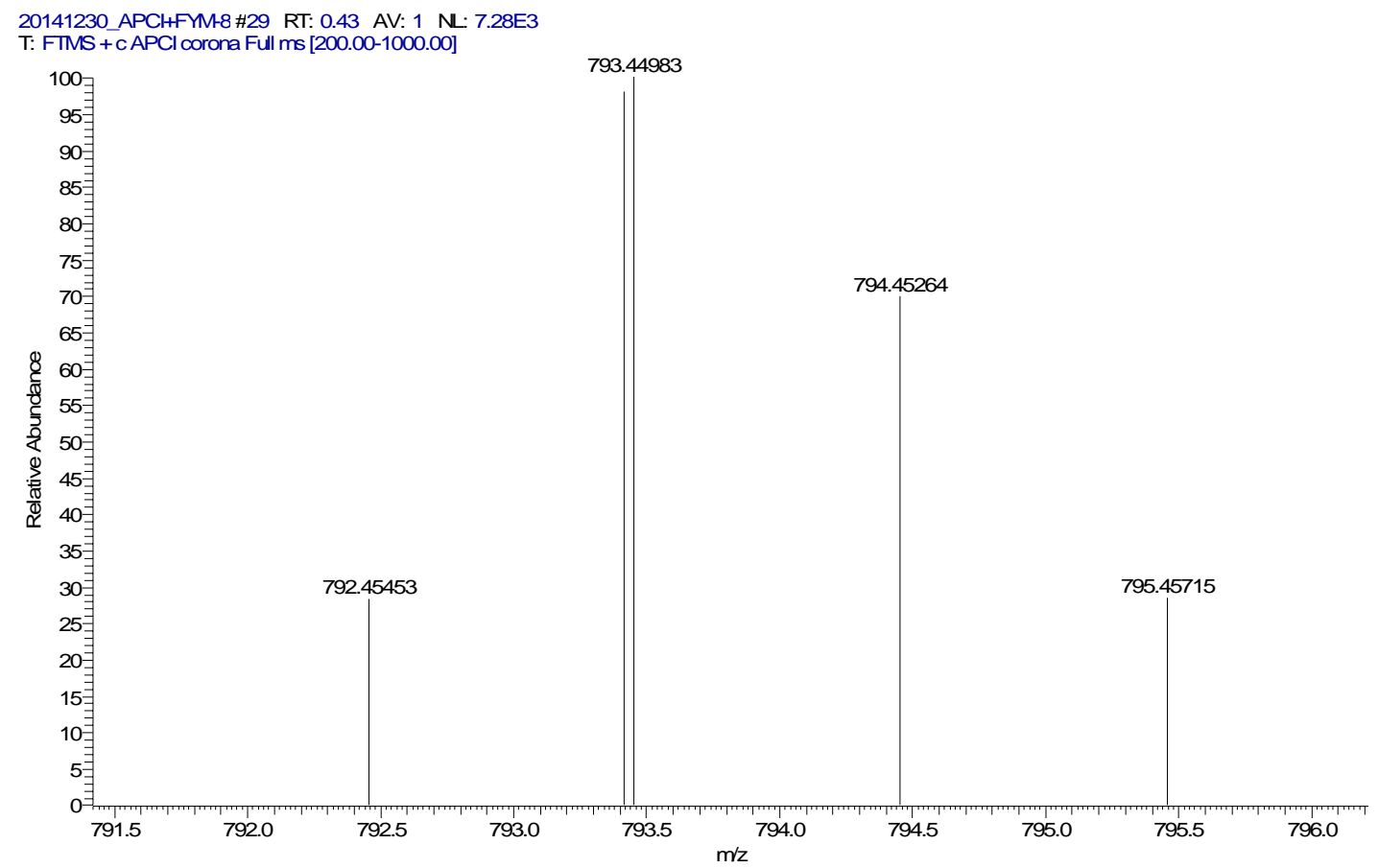

\section{HRMS for $\mathbf{5 a}$}

20141231_APCH+FM-2\#66 RT: 1.39 AV: 1 NL: 1.46E3

T: FIMS + C APCl corona Full ms [800.00-1200.00]

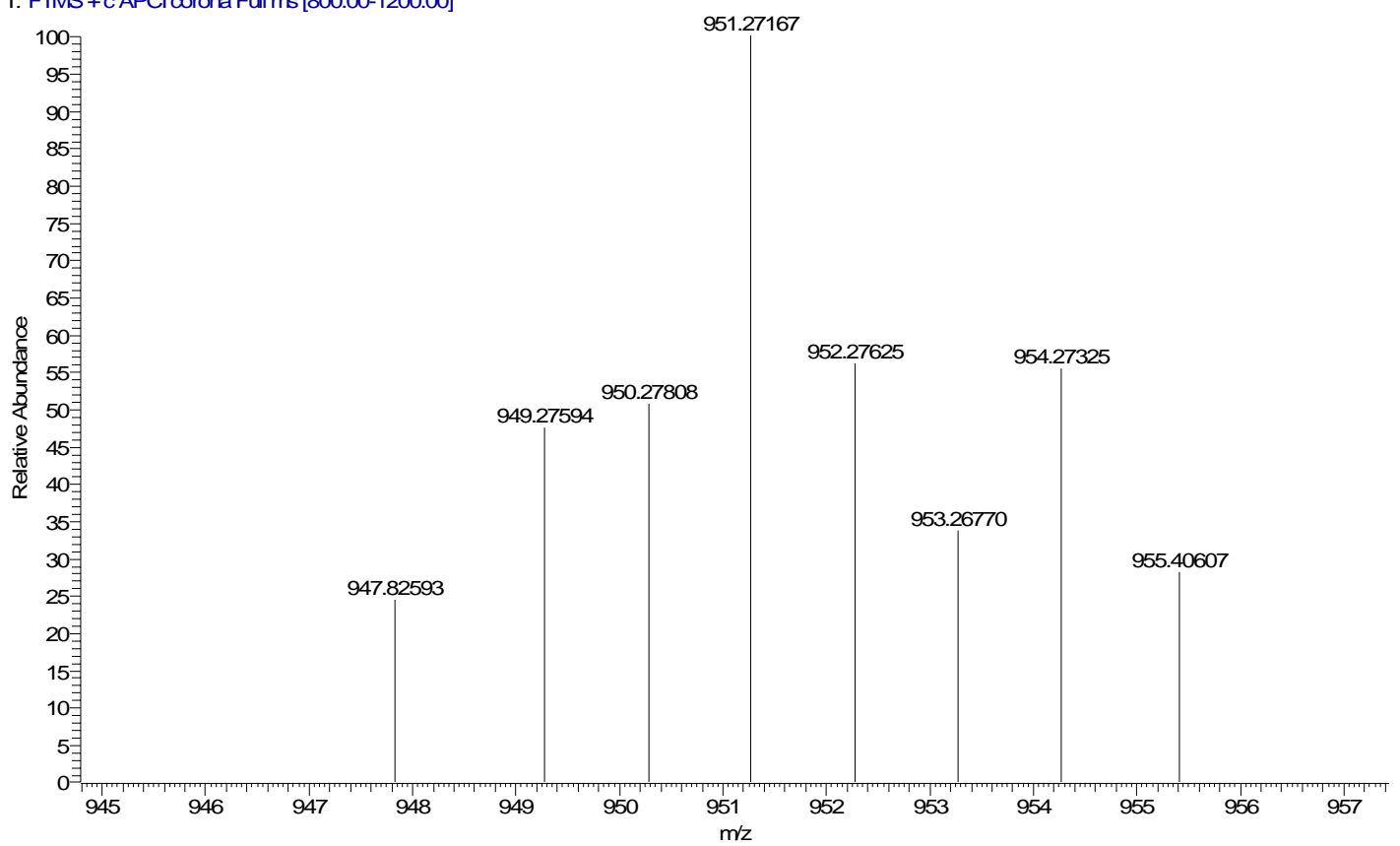

HRMS for $\mathbf{5 a - B r}$ 
20141231_APCHFYM-6 \#5-7 RT: 0.09-0.12 AV: 3 NL: 4.77E4

T: FIMS + c APCl corona Full ms [800.00-1200.00]

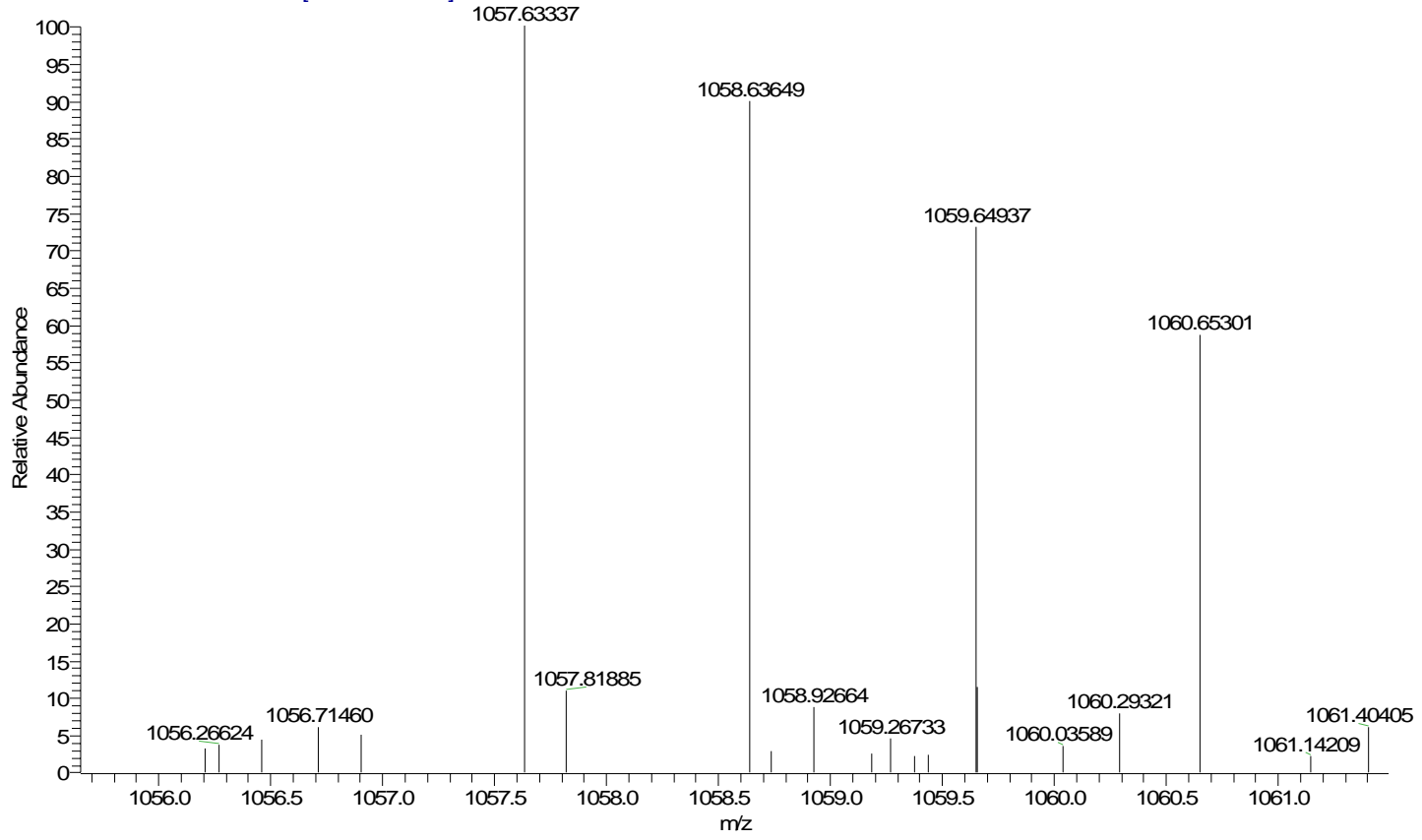

\section{HRMS for $\mathbf{5 b}$}

20141231_APCHFYM-4\#6 RT: 0.10 AV: 1 NL: 2.74E6

T: FIMS + c APCl corona Full ms [800.00-1200.00]

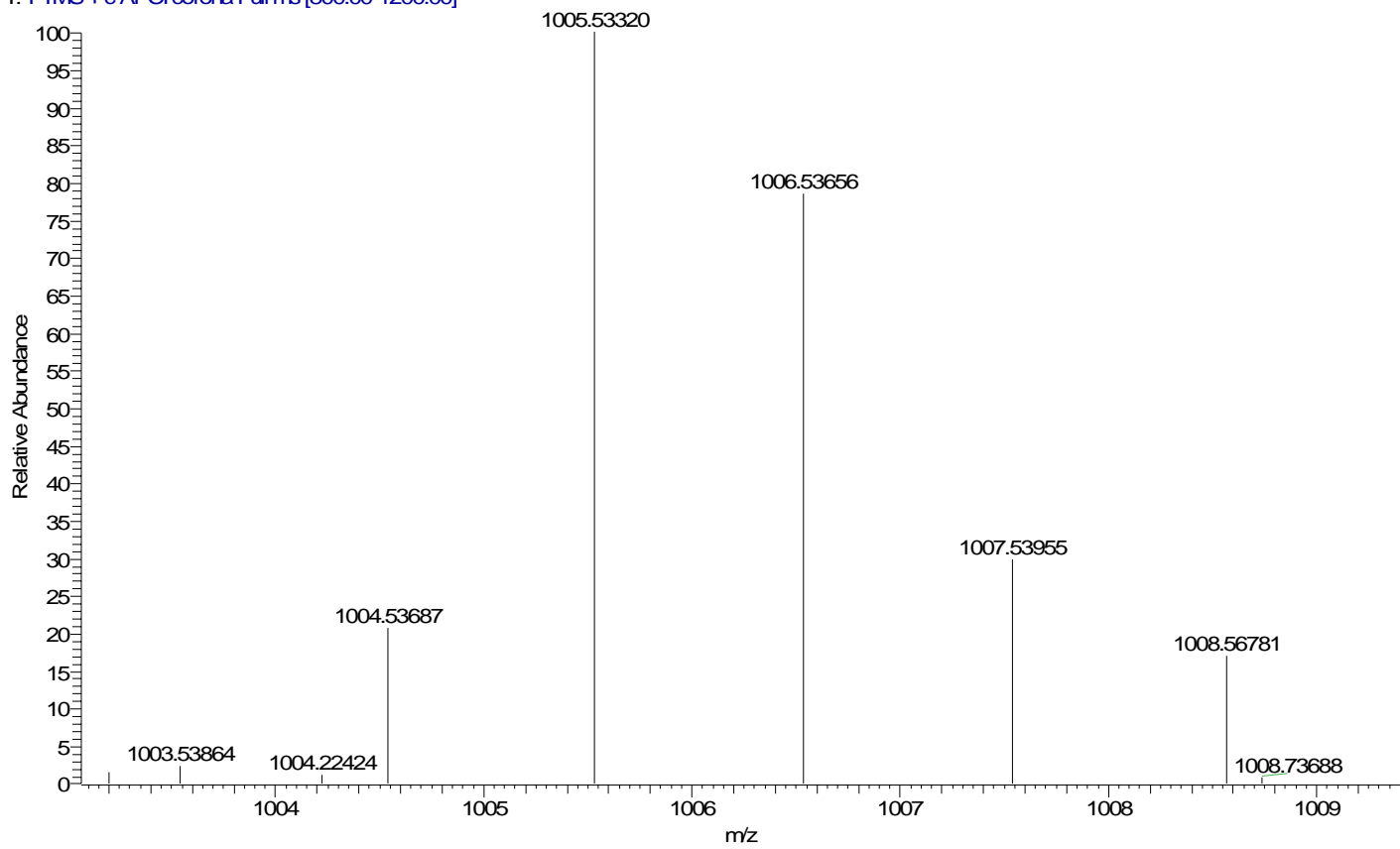

HRMS for 5c 


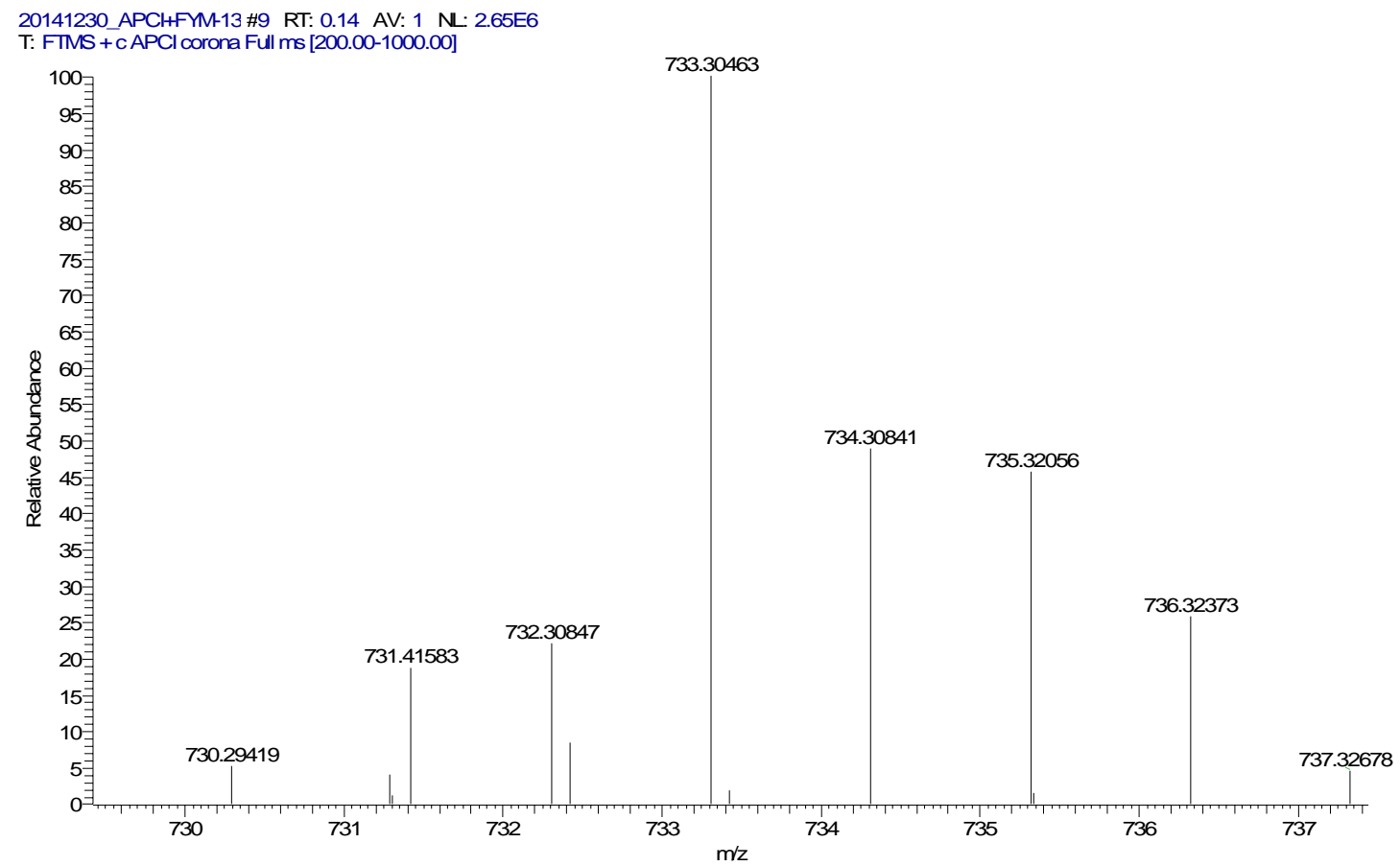

\section{HRMS for 6}




\section{DFT calculation}

Table S5. Selected electronic excitation energies (eV) and oscillator strengths (f), configurations of the low-lying excited states of the probe $\mathbf{4 b}$ and $\mathbf{5 b}$ calculated by TDDFT// B3LYP/6-31+G(d, p), based on the optimized ground state geometries. The TDDFT of all the molecules in dichloromethane were using the Self Consistent Reaction Field (SCRF) method and the Polarizable Continuum Model (PCM).

\begin{tabular}{|c|c|c|c|c|c|c|}
\hline & \multirow{2}{*}{$\begin{array}{l}\text { Electroni } \\
\text { c } \\
\text { transition }\end{array}$} & \multicolumn{5}{|c|}{ TD//B3LYP/6-31+G(d, p) } \\
\hline & & Energy/ & $\mathrm{V}^{[\mathrm{a}]}$ & $f^{[\mathrm{b}]}$ & Composition $^{[c]}$ & $C^{[d]}$ \\
\hline \multirow[t]{4}{*}{$4 \mathbf{b}$} & $\mathrm{S} 0 \rightarrow \mathrm{S} 1$ & $\begin{array}{r}2.2729 \mathrm{eV} \\
\mathrm{nm}\end{array}$ & 545.49 & 0.7976 & $\mathrm{HOMO} \rightarrow \mathrm{LUMO}$ & 0.6975 \\
\hline & $\mathrm{S} 0 \rightarrow \mathrm{S} 2$ & $\begin{array}{r}2.5183 \mathrm{eV} \\
\mathrm{nm}\end{array}$ & 492.33 & 0.0412 & $\begin{array}{c}\text { HOMO - } 1 \rightarrow \\
\text { LUMO }\end{array}$ & 0.6887 \\
\hline & & & & & $\begin{array}{c}\text { HOMO -3 } \rightarrow \\
\text { LUMO }\end{array}$ & 0.1517 \\
\hline & $\mathrm{S} 0 \rightarrow \mathrm{S} 3$ & $\begin{array}{r}2.6753 \mathrm{eV} \\
\mathrm{nm}\end{array}$ & 463.44 & 0.1892 & $\begin{array}{c}\text { HOMO - } 2 \rightarrow \\
\text { LUMO }\end{array}$ & 0.6959 \\
\hline \multirow[t]{5}{*}{$5 \mathbf{b}$} & $\mathrm{S} 0 \rightarrow \mathrm{S} 1$ & $\begin{array}{r}1.9864 \mathrm{eV} \\
\mathrm{nm}\end{array}$ & 624.17 & 1.0337 & $\begin{array}{l}\text { HOMO -1 } \rightarrow \\
\text { LUMO }\end{array}$ & 0.1166 \\
\hline & & & & & $\mathrm{HOMO} \rightarrow \mathrm{LUMO}$ & 0.6964 \\
\hline & $\mathrm{S} 0 \rightarrow \mathrm{S} 2$ & $\begin{array}{r}2.2612 \mathrm{eV} \\
\mathrm{nm}\end{array}$ & 548.31 & 0.1479 & $\begin{array}{c}\text { HOMO - } 1 \rightarrow \\
\text { LUMO }\end{array}$ & 0.6899 \\
\hline & & & & & $\mathrm{HOMO} \rightarrow \mathrm{LUMO}$ & 0.1134 \\
\hline & $\mathrm{S} 0 \rightarrow \mathrm{S} 3$ & $\begin{array}{r}2.3529 \mathrm{eV} \\
\mathrm{nm}\end{array}$ & 526.93 & 0.0328 & $\begin{array}{l}\text { HOMO - } 2 \rightarrow \\
\text { LUMO }\end{array}$ & 0.6993 \\
\hline
\end{tabular}

[a] Only the selected low-lying excited states are presented. [b] Oscillator strength. [c] Only the main configurations are presented. [d] The CI coefficients are in absolute values. 
PCM-DFT optimized coordinates for BODIPY $4 b$ and $5 b$.

\section{Compound 4b}

$\mathrm{B}$

C

$\mathrm{C}$

$\mathrm{C}$

$\mathrm{C}$

$\mathrm{C}$

$\mathrm{C}$

$\mathrm{H}$

$\mathrm{C}$

$\mathrm{H}$

$\mathrm{C}$

$\mathrm{C}$

$\mathrm{H}$

C

$\mathrm{H}$

C

C

$\mathrm{H}$

C

$\mathrm{H}$

C

C

$\mathrm{H}$

C

$\mathrm{H}$

C

C

$\mathrm{H}$

$\mathrm{H}$

$\mathrm{H}$

C

$\mathrm{H}$

$\mathrm{H}$

$\mathrm{H}$

C

$\mathrm{H}$

$\mathrm{H}$

$\mathrm{H}$

C

C

C

\begin{tabular}{|c|c|c|}
\hline 0 & -1 & \\
\hline 2.53482800 & -1.27004800 & 9000 \\
\hline & 54900 & 500 \\
\hline 2.59189100 & 99306200 & 0.05859000 \\
\hline 1.22965200 & 0.54109400 & 5100 \\
\hline 900 & -2.68429100 & -0.2 \\
\hline 2.52564500 & -3.54399000 & -1.2 \\
\hline 1.82101700 & -3.18758300 & -2.0 \\
\hline 2400 & -4.85 & -1.33 \\
\hline 2.63 & 7500 & -2.1 \\
\hline 3.8 & & \\
\hline 4.3 & -4.5 & 500 \\
\hline 4.9 & & 200 \\
\hline & & \\
\hline 800 & -2.5 & 600 \\
\hline 4.8 & -0.1 & -0 \\
\hline 5.5 & -0.8 & -1. \\
\hline 5.02 & -1.3 & 200 \\
\hline 6.9 & -0.9 & -1. \\
\hline 7.4 & -1. & -1 \\
\hline 500 & -0.3 & 100 \\
\hline 7.0 & 900 & 200 \\
\hline 7.5 & & 400 \\
\hline & & \\
\hline 5.13 & 00 & 400 \\
\hline $9.2^{\prime}$ & -0.3 & -0 \\
\hline & & \\
\hline 9.5 & & 900 \\
\hline 9.3 & -0.2 & 500 \\
\hline 10.8 & 300 & 500 \\
\hline 9.936 & & 2900 \\
\hline 9.6 & & 7300 \\
\hline 11.02 & 200 & 2400 \\
\hline 9.63 & & \\
\hline 9.70396300 & 45600 & -0.093 \\
\hline 10.79 & -1.9 & -0.1 \\
\hline & & \\
\hline 9.36 & -2.3 & 7100 \\
\hline 3.13481800 & 2.36215400 & 0.23350200 \\
\hline 3.96 & & -0.74497700 \\
\hline 4.53590000 & 4.18273300 & -0.56513900 \\
\hline
\end{tabular}




\begin{tabular}{|c|c|c|c|}
\hline C & 4.31121200 & 4.93562200 & 0.60001900 \\
\hline $\mathrm{C}$ & 3.49056700 & 4.35907700 & 1.57848000 \\
\hline $\mathrm{C}$ & 2.91631700 & 3.09924700 & 1.40270000 \\
\hline $\mathrm{H}$ & 2.29000600 & 2.68421100 & 2.18687400 \\
\hline $\mathrm{F}$ & 0.18343400 & -2.55795500 & 1.13661700 \\
\hline $\mathrm{N}$ & 1.25014300 & -0.84994400 & -0.15400900 \\
\hline $\mathrm{C}$ & -2.53477600 & -1.27002200 & 0.17209300 \\
\hline $\mathrm{C}$ & -3.40177400 & -0.14552000 & 0.05252700 \\
\hline $\mathrm{C}$ & -2.59185400 & 0.99308700 & -0.05877000 \\
\hline $\mathrm{C}$ & -1.22961100 & 0.54111100 & 0.02081700 \\
\hline $\mathrm{C}$ & -2.95354700 & -2.68427100 & 0.24904300 \\
\hline $\mathrm{C}$ & -2.52566600 & -3.54390100 & 1.27411300 \\
\hline $\mathrm{H}$ & -1.82110600 & -3.18744300 & 2.01417300 \\
\hline $\mathrm{C}$ & -2.98937600 & -4.85348400 & 1.33627100 \\
\hline $\mathrm{H}$ & -2.63562600 & -5.48351700 & 2.14772300 \\
\hline $\mathrm{C}$ & -3.88636200 & -5.37322900 & 0.38769100 \\
\hline $\mathrm{C}$ & -4.30348200 & -4.50743200 & -0.63250700 \\
\hline $\mathrm{H}$ & -4.99069500 & -4.85200800 & -1.39711900 \\
\hline $\mathrm{C}$ & -3.85668500 & -3.18904300 & -0.69707200 \\
\hline $\mathrm{H}$ & -4.20650200 & -2.54705000 & -1.49929600 \\
\hline $\mathrm{C}$ & -4.88182200 & -0.19710800 & 0.05995900 \\
\hline $\mathrm{C}$ & -5.57726600 & -0.85212500 & 1.09039000 \\
\hline $\mathrm{H}$ & -5.01979800 & -1.32597000 & 1.89309300 \\
\hline $\mathrm{C}$ & -6.96712600 & -0.90379100 & 1.09800900 \\
\hline $\mathrm{H}$ & -7.45959600 & -1.42256100 & 1.91609200 \\
\hline $\mathrm{C}$ & -7.73656900 & -0.30782300 & 0.08382800 \\
\hline $\mathrm{C}$ & -7.03700200 & 0.34463200 & -0.93985300 \\
\hline $\mathrm{H}$ & -7.57539200 & 0.82179400 & -1.75135200 \\
\hline $\mathrm{C}$ & -5.64241500 & 0.39977800 & -0.95402800 \\
\hline $\mathrm{H}$ & -5.13892800 & 0.91294600 & -1.76766300 \\
\hline $\mathrm{C}$ & -9.27260400 & -0.39494000 & 0.12938200 \\
\hline $\mathrm{C}$ & -9.78868700 & 0.25558100 & 1.43508500 \\
\hline $\mathrm{H}$ & -9.50379400 & 1.31273500 & 1.48482600 \\
\hline $\mathrm{H}$ & -9.38685900 & -0.24083000 & 2.32457300 \\
\hline $\mathrm{H}$ & -10.88295900 & 0.19482900 & 1.48539100 \\
\hline $\mathrm{C}$ & -9.93690600 & 0.32585500 & -1.05897300 \\
\hline $\mathrm{H}$ & -9.69275500 & 1.39418700 & -1.07607700 \\
\hline $\mathrm{H}$ & -11.02661800 & 0.23690400 & -0.98236400 \\
\hline $\mathrm{H}$ & -9.63740100 & -0.10891300 & -2.01934600 \\
\hline $\mathrm{C}$ & -9.70389700 & -1.88051000 & 0.09421900 \\
\hline $\mathrm{H}$ & -10.79705600 & -1.96305000 & 0.13821100 \\
\hline $\mathrm{H}$ & -9.29211200 & -2.44353200 & 0.93831600 \\
\hline $\mathrm{H}$ & -9.36267400 & -2.36499300 & -0.82776000 \\
\hline $\mathrm{C}$ & -3.13479800 & 2.36218300 & -0.23360900 \\
\hline
\end{tabular}




\begin{tabular}{|c|c|c|c|}
\hline $\mathrm{C}$ & -3.96849600 & 2.92576000 & 0.74498800 \\
\hline $\mathrm{C}$ & -4.53578300 & 4.18276100 & 0.56520300 \\
\hline $\mathrm{C}$ & -4.31129600 & 4.93561800 & -0.60001500 \\
\hline $\mathrm{C}$ & -3.49078400 & 4.35906600 & -1.57858400 \\
\hline $\mathrm{C}$ & -2.91647300 & 3.09925700 & -1.40285200 \\
\hline $\mathrm{H}$ & -2.29027900 & 2.68420800 & -2.18711300 \\
\hline $\mathrm{F}$ & -0.18358100 & -2.55700200 & -1.13836400 \\
\hline $\mathrm{N}$ & -1.25009100 & -0.84993100 & 0.15363700 \\
\hline $\mathrm{H}$ & -4.17240200 & 2.36877300 & 1.65507000 \\
\hline $\mathrm{H}$ & 4.17271100 & 2.36871700 & -1.65501700 \\
\hline $\mathrm{C}$ & 0.00002500 & 1.23654000 & -0.00018600 \\
\hline $\mathrm{H}$ & 3.28647100 & 4.88918700 & 2.50222300 \\
\hline $\mathrm{H}$ & 5.16955200 & 4.58055500 & -1.35327500 \\
\hline $\mathrm{H}$ & -5.16931900 & 4.58059200 & 1.35342600 \\
\hline $\mathrm{H}$ & -3.28683700 & 4.88915700 & -2.50237000 \\
\hline $\mathrm{C}$ & -4.95405600 & 6.32513800 & -0.75611100 \\
\hline $\mathrm{C}$ & -6.49388600 & 6.19470200 & -0.68022000 \\
\hline $\mathrm{H}$ & -6.87233700 & 5.55515500 & -1.48576900 \\
\hline $\mathrm{H}$ & -6.81986100 & 5.76036400 & 0.27054600 \\
\hline $\mathrm{H}$ & -6.96700100 & 7.17979100 & -0.77687300 \\
\hline $\mathrm{C}$ & -4.46157200 & 7.24793500 & 0.38427900 \\
\hline $\mathrm{H}$ & -3.37129800 & 7.35646300 & 0.35414700 \\
\hline $\mathrm{H}$ & -4.90709300 & 8.24594700 & 0.28962500 \\
\hline $\mathrm{H}$ & -4.73060100 & 6.85527000 & 1.37046200 \\
\hline $\mathrm{C}$ & -4.59449700 & 6.98974200 & -2.09862400 \\
\hline $\mathrm{H}$ & -3.51393000 & 7.14049200 & -2.20231500 \\
\hline $\mathrm{H}$ & -4.94046900 & 6.39680100 & -2.95292300 \\
\hline $\mathrm{H}$ & -5.07338400 & 7.97326600 & -2.16397700 \\
\hline $\mathrm{C}$ & 4.95391200 & 6.32516000 & 0.75616700 \\
\hline $\mathrm{C}$ & 6.49375200 & 6.19477000 & 0.68038800 \\
\hline $\mathrm{H}$ & 6.87216500 & 5.55523200 & 1.48596200 \\
\hline $\mathrm{H}$ & 6.81981100 & 5.76044500 & -0.27035700 \\
\hline $\mathrm{H}$ & 6.96682700 & 7.17987400 & 0.77707800 \\
\hline $\mathrm{C}$ & 4.59423300 & 6.98974600 & 2.09865600 \\
\hline $\mathrm{H}$ & 3.51365300 & 7.14042900 & 2.20228700 \\
\hline $\mathrm{H}$ & 4.94019900 & 6.39683200 & 2.95297700 \\
\hline $\mathrm{H}$ & 5.07305200 & 7.97330400 & 2.16402800 \\
\hline $\mathrm{C}$ & 4.46148200 & 7.24794300 & -0.38425700 \\
\hline $\mathrm{H}$ & 3.37119200 & 7.35635700 & -0.35426200 \\
\hline $\mathrm{H}$ & 4.90688500 & 8.24600100 & -0.28951800 \\
\hline $\mathrm{H}$ & 4.73067100 & 6.85533200 & -1.37041700 \\
\hline $\mathrm{C}$ & -4.36830100 & -6.83018500 & 0.49875200 \\
\hline $\mathrm{C}$ & 4.36822900 & -6.83026900 & -0.49870600 \\
\hline $\mathrm{C}$ & 5.09614300 & -7.02871400 & -1.84985300 \\
\hline
\end{tabular}




\begin{tabular}{|c|c|c|c|}
\hline $\mathrm{H}$ & 5.96985400 & -6.37096700 & -1.92407000 \\
\hline $\mathrm{H}$ & 5.44123400 & -8.06537000 & -1.94896200 \\
\hline $\mathrm{H}$ & 4.44173700 & -6.81235100 & -2.70067000 \\
\hline $\mathrm{C}$ & 5.34312200 & -7.21308000 & 0.63121400 \\
\hline $\mathrm{H}$ & 5.65944400 & -8.25521400 & 0.50833000 \\
\hline $\mathrm{H}$ & 6.24511900 & -6.59057300 & 0.62075200 \\
\hline $\mathrm{H}$ & 4.87733200 & -7.12391900 & 1.61918800 \\
\hline $\mathrm{C}$ & 3.15079700 & -7.78251200 & -0.42820300 \\
\hline $\mathrm{H}$ & 2.62100200 & -7.67015900 & 0.52443500 \\
\hline $\mathrm{H}$ & 2.43361700 & -7.58767400 & -1.23219600 \\
\hline $\mathrm{H}$ & 3.47804600 & -8.82597000 & -0.51633100 \\
\hline $\mathrm{C}$ & -3.15092500 & -7.78251100 & 0.42849900 \\
\hline $\mathrm{H}$ & -2.62101100 & -7.67029400 & -0.52408900 \\
\hline $\mathrm{H}$ & -2.43382900 & -7.58763300 & 1.23255700 \\
\hline $\mathrm{H}$ & -3.47825100 & -8.82593800 & 0.51670200 \\
\hline $\mathrm{C}$ & -5.34309400 & -7.21306300 & -0.63123500 \\
\hline $\mathrm{H}$ & -5.65946200 & -8.25517700 & -0.50829200 \\
\hline $\mathrm{H}$ & -6.24507300 & -6.59052900 & -0.62092100 \\
\hline $\mathrm{H}$ & -4.87720200 & -7.12400500 & -1.61917000 \\
\hline $\mathrm{C}$ & -5.09638000 & -7.02842800 & 1.84984400 \\
\hline $\mathrm{H}$ & -5.97004200 & -6.37059700 & 1.92390300 \\
\hline $\mathrm{H}$ & -5.44156900 & -8.06504500 & 1.94901800 \\
\hline $\mathrm{H}$ & -4.44204100 & -6.81203400 & 2.70070400 \\
\hline $\mathrm{C}$ & 0.00004500 & 2.72688300 & -0.00019800 \\
\hline $\mathrm{C}$ & -0.50893600 & 3.43743700 & 1.09531500 \\
\hline $\mathrm{C}$ & 0.50906700 & 3.43738400 & -1.09572600 \\
\hline $\mathrm{C}$ & -0.50225100 & 4.83082500 & 1.09814700 \\
\hline $\mathrm{H}$ & -0.90601200 & 2.89242300 & 1.94639800 \\
\hline $\mathrm{C}$ & 0.50253000 & 4.83077500 & -1.09855500 \\
\hline $\mathrm{H}$ & 0.90612600 & 2.89232900 & -1.94679100 \\
\hline $\mathrm{C}$ & 0.00018300 & 5.53086400 & -0.00020000 \\
\hline $\mathrm{H}$ & -0.89594500 & 5.36923100 & 1.95583000 \\
\hline $\mathrm{H}$ & 0.89629700 & 5.36914000 & -1.95623000 \\
\hline $\mathrm{H}$ & 0.00024200 & 6.61782000 & -0.00019800 \\
\hline
\end{tabular}

$\mathrm{E}\left(\mathrm{RB}_{3} \mathrm{LYP}\right)=-3242.2831969$ a.u.

Imaginary Freq $=0$

\section{Compound 5b}

$\begin{array}{lrrr}\text { B } & -0.05957100 & -1.81131500 & 0.20075100 \\ \mathrm{C} & -2.62145100 & -1.24944300 & 0.40661500 \\ \mathrm{C} & -3.43014100 & -0.07681600 & 0.28643300 \\ \mathrm{C} & -2.56234000 & 1.02839700 & 0.26858900 \\ \mathrm{C} & -1.23653200 & 0.50061600 & 0.35314800 \\ & & \mathbf{S 6 3 / S 6 7} & \end{array}$




$\begin{array}{rrr}-3.21925900 & -2.56388000 & 0.50182400 \\ -2.49544800 & -3.73838900 & 0.80899200 \\ -1.44753600 & -3.67001400 & 1.05235500 \\ -3.10798900 & -4.97385900 & 0.85003600 \\ -2.50174000 & -5.84183900 & 1.09251000 \\ -4.48580500 & -5.12011900 & 0.59324500 \\ -5.20753300 & -3.95906300 & 0.33914300 \\ -6.27133400 & -4.04938100 & 0.17705900 \\ -4.62824500 & -2.67202800 & 0.30016800 \\ -4.87436800 & -0.18092900 & 0.14876100 \\ -5.46102900 & -1.47359600 & 0.09803500 \\ -6.85533200 & -1.57138700 & -0.11055200 \\ -7.30101300 & -2.55349900 & -0.17090200 \\ -7.68919100 & -0.46699000 & -0.24521100 \\ -7.08589400 & 0.80263300 & -0.15460000 \\ -7.69008800 & 1.70160400 & -0.23909000 \\ -5.72375300 & 0.94014000 & 0.03529900 \\ -5.30736800 & 1.93514000 & 0.09537500 \\ -9.20500100 & -0.58289400 & -0.48254200 \\ -9.96217200 & 0.13883100 & 0.65789500 \\ -9.69605200 & 1.19926300 & 0.71819300 \\ -9.73630300 & -0.31779000 & 1.62830000 \\ -11.04530000 & 0.07618700 & 0.49582700 \\ -9.56093800 & 0.08256800 & -1.83364900 \\ -9.27610300 & 1.13975400 & -1.85344300 \\ -10.64097300 & 0.02377000 & -2.01717500 \\ -9.04689400 & -0.41705500 & -2.66268400 \\ -9.68835400 & -2.04466700 & -0.52598600 \\ -10.77107600 & -2.07037800 & -0.69356700 \\ -9.48826900 & -2.56895800 & 0.41555500 \\ -9.21639300 & -2.60761000 & -1.33940000 \\ -2.95726100 & 2.43921900 & 0.01299100 \\ -3.27778700 & 3.32850100 & 1.04288800 \\ -3.71443800 & 4.62511700 & 0.76393500 \\ -3.85780800 & 5.08562900 & -0.55169400 \\ -3.54006400 & 4.18216700 & -1.58024500 \\ -3.09976700 & 2.89039800 & -1.30887100 \\ -2.87372700 & 2.21408300 & -2.12897100 \\ -0.33193300 & -2.58206000 & -0.93011300 \\ -1.30369700 & -0.88987600 & 0.41324500 \\ 2.51138500 & -1.33934300 & -0.13551700 \\ 3.37707200 & -0.20229700 & -0.04676900 \\ 2.56370400 & 0.93221000 & 0.10214800 \\ 1.21277300 & 0.46217800 & 0.14244000 \\ & & \end{array}$


$\mathrm{H}$

$\mathrm{H}$

C

$\mathrm{H}$
3.05077800

2.26170800

1.19335100

2.82668700

2.16631000

4.22151000

5.00204300

6.07470400

4.47109500

4.82432700

5.36534000

6.76970500

7.18195700

7.65464100

7.09194300

7.73381700

5.72334900

5.34396700

9.18213900

9.82457100

9.59592900

9.46428100

10.91602600

9.72461000

9.48873500

10.81554400

9.29572400

9.60972800

10.70270200

9.28244800

9.21185000

3.04508100

3.34826600

3.88847400

4.15220000

3.84222400

3.30402800

3.08991200

0.18551600

1.21342000

3.17295800

$-3.18693700$

0.00753000

$-3.63891600$
$-2.67254500$

$-3.82526500$

$-3.73304700$

$-5.07454500$

$-5.92014000$

$-5.26189000$

$-4.12607300$

$-4.24708100$

$-2.82737700$

$-0.35761100$

$-1.66647400$

$-1.82027900$

$-2.81658700$

$-0.75497300$

0.53317200

1.40455900

0.72431500

1.73190200

$-0.93309300$

$-0.16737400$

0.90294700

$-0.55442900$

$-0.27616400$

$-0.36278700$

0.70031100

$-0.46922600$

$-0.89460200$

$-2.40955200$

$-2.48052000$

$-2.86826600$

$-3.00519000$

2.33874200

2.98167400

4.26849600

4.96615800

4.31248600

3.02909300

2.55169200

$-2.60510800$

$-0.92599100$

2.46183200

3.00498800

1.16785500

4.48734500
$-0.32205900$

$-0.54194200$

$-0.63337300$

$-0.69484100$

$-0.86431000$

$-0.64815300$

$-0.46660000$

$-0.45688500$

$-0.30934200$

$-0.06369800$

$-0.15905100$

$-0.11720800$

$-0.17387700$

0.00161600

0.08389900

0.17937100

0.05542300

0.13416900

0.04847900

$-1.13297200$

$-1.09762800$

$-2.09297200$

$-1.10978500$

1.38109200

1.49605700

1.42543200

2.23808200

$-0.04879100$

$-0.01063300$

$-0.98885800$

0.78075400

0.11332000

$-1.09308200$

$-1.10923600$

0.07712100

1.28224300

1.30526900

2.25679100

1.32224700

$-0.02184900$

$-2.03130400$

2.07541700

0.33489900

$-2.61864800$ 
H

$\mathrm{H}$

$\mathrm{H}$

C

C

$\mathrm{H}$

$\mathrm{H}$

$\mathrm{H}$

C

$\mathrm{H}$

$\mathrm{H}$

$\mathrm{H}$

C

$\mathrm{H}$

$\mathrm{H}$

$\mathrm{H}$

C

C

$\mathrm{H}$

$\mathrm{H}$

$\mathrm{H}$

C

$\mathrm{H}$

$\mathrm{H}$

$\mathrm{H}$

C

$\mathrm{H}$

$\mathrm{H}$

$\mathrm{H}$

C

C

C

$\mathrm{H}$

$\mathrm{H}$

$\mathrm{H}$

C

$\mathrm{H}$

$\mathrm{H}$

$\mathrm{H}$

C

$\mathrm{H}$

$\mathrm{H}$

$\mathrm{H}$

C

$\begin{array}{rrr}-3.94333100 & 5.27787300 & 1.59896500 \\ 4.10879900 & 4.72052200 & -2.07022000 \\ 4.02755000 & 4.80994400 & 2.23026400 \\ 4.75628500 & 6.38203200 & 0.10110500 \\ 5.02980700 & 6.92605000 & -1.31375900 \\ 5.74347600 & 6.29971900 & -1.86095600 \\ 4.11179300 & 6.99767700 & -1.90824900 \\ 5.45804300 & 7.93248200 & -1.24604500 \\ 3.77677400 & 7.34904400 & 0.80744900 \\ 3.56816300 & 7.03878100 & 1.83655300 \\ 4.19783300 & 8.36141300 & 0.84203900 \\ 2.82075000 & 7.39542500 & 0.27360200 \\ 6.09638500 & 6.35746900 & 0.87419700 \\ 5.96581900 & 6.01610800 & 1.90640900 \\ 6.81589600 & 5.68777100 & 0.38942100 \\ 6.53611400 & 7.36181500 & 0.90813900 \\ -4.33638000 & 6.50778800 & -0.89505800 \\ -4.62436300 & 7.34829400 & 0.36330500 \\ -5.41284900 & 6.90221500 & 0.97999000 \\ -3.73052500 & 7.46859100 & 0.98594000 \\ -4.96096700 & 8.34932500 & 0.07067200 \\ -5.63606500 & 6.42851700 & -1.73083400 \\ -5.48814500 & 5.87259900 & -2.66255100 \\ -6.43421500 & 5.93096000 & -1.16815400 \\ -5.98252300 & 7.43550200 & -1.99420800 \\ -3.24424700 & 7.23213600 & -1.71788400 \\ -3.02934200 & 6.71142100 & -2.65685000 \\ -3.56601600 & 8.25067800 & -1.96757900 \\ -2.30861000 & 7.29918500 & -1.15093400 \\ 4.81537200 & -6.67029900 & -0.81253700 \\ -5.12811400 & -6.51693100 & 0.62039400 \\ -4.92955400 & -7.14769800 & 2.01981500 \\ -5.41023400 & -6.54023000 & 2.79515000 \\ -5.37165700 & -8.15108900 & 2.05036200 \\ -3.87007600 & -7.24258900 & 2.27881500 \\ -6.63831000 & -6.48309200 & 0.31939900 \\ -7.04104200 & -7.50203600 & 0.34096200 \\ -7.19063000 & -5.89518200 & 1.06149900 \\ -6.84735300 & -6.06742700 & -0.67300000 \\ -4.44506700 & -7.40848600 & -0.44463300 \\ -4.58041000 & -6.99159300 & -1.44910500 \\ -3.36927600 & -7.50487200 & -0.26600000 \\ -4.87835600 & -8.41623300 & -0.43243000 \\ 4.27154800 & -7.58463700 & 0.31171100\end{array}$

S66 / S67 


$\begin{array}{lrrr}\mathrm{H} & 4.55931500 & -7.20542100 & 1.29882900 \\ \mathrm{H} & 3.17928600 & -7.65522000 & 0.28703300 \\ \mathrm{H} & 4.67479800 & -8.59917500 & 0.20526200 \\ \mathrm{C} & 6.35393500 & -6.68031600 & -0.73725600 \\ \mathrm{H} & 6.72075200 & -7.70643000 & -0.85307100 \\ \mathrm{H} & 6.80618000 & -6.07781700 & -1.53341100 \\ \mathrm{H} & 6.71870400 & -6.30618200 & 0.22619400 \\ \mathrm{C} & 4.39679000 & -7.24527200 & -2.18707400 \\ \mathrm{H} & 4.77572200 & -6.62111300 & -3.00435700 \\ \mathrm{H} & 4.80089100 & -8.25704600 & -2.31567100 \\ \mathrm{H} & 3.30856400 & -7.30529300 & -2.28997900 \\ \mathrm{C} & 0.03348400 & 2.62828000 & 0.66114800 \\ \mathrm{C} & 0.14039800 & 3.62282000 & -0.31588000 \\ \mathrm{C} & -0.05730400 & 3.00195200 & 2.00997400 \\ \mathrm{C} & 0.15760500 & 4.96841200 & 0.04963500 \\ \mathrm{H} & 0.20537600 & 3.34216500 & -1.36213300 \\ \mathrm{C} & -0.02914700 & 4.34700100 & 2.37514100 \\ \mathrm{H} & -0.14514600 & 2.23134000 & 2.77111500 \\ \mathrm{C} & 0.07634600 & 5.33393200 & 1.39436900 \\ \mathrm{H} & 0.23763100 & 5.73149900 & -0.71962300 \\ \mathrm{H} & -0.09348600 & 4.62265900 & 3.42457000 \\ \mathrm{H} & 0.09497700 & 6.38350200 & 1.67588900\end{array}$

$\mathrm{E}\left(\mathrm{RB}_{3} \mathrm{LYP}\right)=-3239.92011329$ a.u.

Imaginary Freq $=0$ 